

\section{Effect van strooiselverwijdering bij leghennen in volièrehuisvesting op de emissie van ammoniak, geur, broeikasgassen en fijnstof}


J. Mosquera, R. van Emous, T. van Hattum, G. Nijeboer, J.M.G. Hol, H.J. van Dooren, en N.W.M. Ogink, 2016. Effect van strooiselverwijdering bij leghennen in volièrehuisvesting op de emissie van ammoniak, geur, broeikasgassen en fijnstof. Wageningen UR (University \& Research centre) Livestock Research, Livestock Research Rapport 995.

\section{Samenvatting}

In dit rapport worden de resultaten gerapporteerd van de metingen die in het kader van de Programmatische Aanpak Stikstof (PAS) zijn uitgevoerd om het effect van het verwijderen van strooisel (om een dunne strooisel-laag in de stal te realiseren) op de emissie van ammoniak, fijnstof, geur en overige broeikasgassen (methaan, lachgas) bij het huisvesten van leghennen te bepalen. Het verwijderen van strooisel in de stal leidde tot significant lagere $\mathrm{NH}_{3}$ en $\mathrm{PM} 10$-emissies (gemiddeld 20$22 \%$ lager). Hoewel in zeven van de negen metingen strooiselverwijdering tot minder geur leidde ( $\sim 25 \%$ emissiereductie), was er geen significant aantoonbaar geurverwijderingseffect. Voor $\mathrm{CH}_{4}$ en $\mathrm{N}_{2} \mathrm{O}$ werd geen significant effect in emissies geconstateerd door het verwijderen van strooisel. Door een dunne strooisel-laag (kleiner dan $2-3 \mathrm{~cm}$ ) te realiseren zou een $\mathrm{NH}_{3}$ - en $\mathrm{PM} 10$-emissiereductie van 25-35\% kunnen worden bereikt.

\section{Summary}

This report summarizes the results of measurements performed in the framework of the programmatic Approach nitrogen (PAS) to determine the effect of removing litter from livestock housing of laying hens (to maintain a thin layer of litter in the animal building) on the emission of ammonia, fine dust, odour and greenhouse gases (methane, nitrous oxide). Removing the litter led to significantly lower emissions of $\mathrm{NH}_{3}$ and PM10 (on average 20-22\% lower emissions). Although in seven of all nine measurements removing the litter resulted in lower odour emissions ( $25 \%$ emission reduction), no significant effect was found of removing the litter on odour removal. For $\mathrm{CH}_{4}$ and $\mathrm{N}_{2} \mathrm{O}$, removing litter did not result in significantly lower emissions. When a thin litter layer (less than 2-3 cm) can be maintained, a reduction of $25-35 \%$ in $\mathrm{NH}_{3}$ and PM10 emissions may be achieved.

Dit rapport is gratis te downloaden op http://dx.doi.org/10.18174/401249 of op www.wur.nl/livestock-research (onder Wageningen Livestock Research publicaties).

(C) 2016 Wageningen UR Livestock Research, Postbus 338, 6700 AH Wageningen, T 03174839 53, E info.livestockresearch@wur.nl, www.wageningenUR.nl/livestockresearch. Livestock Research is onderdeel van Wageningen UR (University \& Research centre).

Livestock Research aanvaardt geen aansprakelijkheid voor eventuele schade voortvloeiend uit het gebruik van de resultaten van dit onderzoek of de toepassing van de adviezen.

Alle rechten voorbehouden. Niets uit deze uitgave mag worden vermenigvuldigd en/of openbaar gemaakt worden door middel van druk, fotokopie, microfilm of op welke wijze dan ook zonder voorafgaande toestemming van de uitgever of auteur.

De certificering volgens ISO 9001 door DNV onderstreept ons kwaliteitsniveau. Op als onze onderzoeksopdrachten zijn de Algemene Voorwaarden van de Animal Sciences Group van toepassing. Deze zijn gedeponeerd bij de Arrondissementsrechtbank Zwolle. 


\section{Inhoud}

Woord vooraf $\quad 5$

$\begin{array}{ll}\text { Samenvatting } & 7\end{array}$

1

Inleiding

$\begin{array}{lr}\text { Materiaal en methoden } & 10\end{array}$

2.1 Meetlocaties $\quad 10$

2.1.1 Meetlocatie $1 \quad 10$

2.1.2 Meetlocatie 2 12

2.1.3 Meetlocatie $3 \quad 14$

2.1.4 Meetlocatie $4 \quad 16$

2.1.5 Meetlocatie $5 \quad 18$

2.2 Metingen $\quad 20$

2.2.1 Meetpunten 20

2.2.2 Meetapparatuur 23

$\begin{array}{ll}2.2 .3 \text { Productiegegevens } & 26\end{array}$

$\begin{array}{lll}2.3 & \text { Rekenmethoden } & 27\end{array}$

$\begin{array}{ll}2.3 .1 \text { Ventilatiedebiet } & 27\end{array}$

$\begin{array}{ll}2.3 .2 \text { Emissies } & 27\end{array}$

$\begin{array}{ll}2.3 .3 \text { Emissiereductie } & 28\end{array}$

$\begin{array}{ll}2.3 .4 & \text { Statistische analyse }\end{array}$

$3 \quad$ Resultaten en discussie $\quad 29$

$\begin{array}{lll}3.1 & \text { Meetomstandigheden } & 29\end{array}$

$\begin{array}{lll}3.2 & \text { Strooiselmonsters } & 30\end{array}$

$\begin{array}{lll}3.3 & \text { Ventilatiedebieten } & 36\end{array}$

$\begin{array}{lll}3.4 & \text { Ammoniak }\left(\mathrm{NH}_{3}\right) & 37\end{array}$

3.5 Fijnstof (PM10) 39

$\begin{array}{lll}3.6 & \text { Geur } & 42\end{array}$

$\begin{array}{lll}3.7 & \text { Methaan }\left(\mathrm{CH}_{4}\right) & 44\end{array}$

3.8 Lachgas $\left(\mathrm{N}_{2} \mathrm{O}\right) \quad 46$

4 Conclusies $\quad 53$

$\begin{array}{ll}\text { Literatuur } & 54\end{array}$

Bijlage 1 Foto's van de bedrijfssituatie $\quad 55$

$\begin{array}{lll}\text { Bijlage } 2 \text { Voersamenstelling } & 65\end{array}$ 



\section{Woord vooraf}

In het kader van de Programmatische Aanpak Stikstof (PAS) is er behoefte om voer- en managementmaatregelen op te nemen die toegepast zouden kunnen worden om de uitstoot van ammoniak $\left(\mathrm{NH}_{3}\right)$ te verminderen. Een mogelijke oplossing om de emissie van zowel $\mathrm{NH}_{3}$ als fijnstof te reduceren is het toepassen van een dunnere strooisel-laag.

In dit rapport worden de resultaten weergegeven van metingen die uitgevoerd zijn om het effect van het verwijderen van strooisel (om een dunne strooisel-laag in de stal te realiseren) op de emissie van ammoniak, fijnstof, geur en overige broeikasgassen (methaan, lachgas) bij het huisvesten van leghennen in de praktijk te bepalen.

Deze studie is uitgevoerd door Wageningen UR Livestock Research in opdracht van en gefinancierd door het Ministerie van Economische Zaken.

Julio Mosquera, projectleider 


\section{Samenvatting}

In dit rapport worden de resultaten gerapporteerd van de metingen die in het kader van de Programmatische Aanpak Stikstof (PAS) zijn uitgevoerd om het effect van het verwijderen van strooisel (om een dunne strooisel-laag in de stal te realiseren) op de emissie van ammoniak, fijnstof, geur en overige broeikasgassen (methaan, lachgas) bij het huisvesten van leghennen te bepalen. De metingen zijn uitgevoerd volgens het zogenaamde 'case-control in de tijd' strategie binnen dezelfde stal. Aan het begin van een meetperiode werd een 24-uursmeting verricht in de stal zoals aangetroffen, d.w.z. met een dikke strooisel-laag (controle). Daarna werd een deel van de strooisel uit de stal verwijderd, en na een periode van 2-3 dagen een tweede 24-uursmeting uitgevoerd in de stal met een dunne strooisel-laag (case).

$\mathrm{NH}_{3}$ - en PM10-emissies na verwijdering van strooisel (case) waren zwak significant $(0,05<\mathrm{P}<0,10)$ verschillend van de emissies vóór verwijdering van strooisel (controle). De gemiddelde $\mathrm{NH}_{3}{ }^{-}$ emissiereductie door het verwijderen van strooisel in de stal over alle metingen was in onderhavige studie $20 \pm 6 \%$. Voor PM10 werd een gemiddelde emissiereductie van $22 \pm 5 \%$ gemeten.

Voor zowel $\mathrm{NH}_{3}$ als PM10 was de dikte van de strooisel-laag na het verwijderen van de strooisel belangrijker dan de hoeveelheid strooisel die verwijderd werd om emissies te kunnen reduceren. De reductie is groter wanneer de dikte van de strooisel-laag na verwijdering kleiner is dan $2-3 \mathrm{~cm}$. In dat geval kan een $\mathrm{NH}_{3}$ - en PM10-emissiereductie van $25-35 \%$ worden bereikt.

Deze studie laat geen significant effect zien door het verwijderen van strooisel in de stal op de geuremissies. Dit komt voornamelijk door de eerste twee meetseries, waar een hogere in plaats van een lagere geuremissies werd gemeten na het verwijderen van het strooisel. De andere zeven meetseries laten zien dat strooiselverwijdering potentie heeft om geuremissies sterk te kunnen reduceren. De gemiddelde emissiereductie van deze zeven metingen was $26 \pm 5 \%$, en het effect was significant $(P<0,05)$. Er is geen direct verband aangetroffen tussen de geuremissie en de dikte van de strooisel-laag na het verwijderen van de strooisel, of tussen de geuremissie en de hoeveelheid strooisel die verwijderd werd.

De data in onderhavige studie laat geen significant effect zien van het verwijderen van strooisel in de stal op de $\mathrm{CH}_{4}$ - en $\mathrm{N}_{2} \mathrm{O}$-emissies. $\mathrm{Er}$ is ook geen directe verband aangetroffen tussen deze emissies en de dikte van de strooisel-laag na het verwijderen van de strooisel, of tussen deze emissies en de hoeveelheid strooisel die werd verwijderd. 
In het kader van de Programmatische Aanpak Stikstof (PAS) is er behoefte om voer- en managementmaatregelen op te nemen die toegepast zouden kunnen worden om de uitstoot van ammoniak $\left(\mathrm{NH}_{3}\right)$ te verminderen. Aanvullende managementmaatregelen betreffen maatregelen die niet gebonden zijn aan de uitvoering van een stalsysteem, zoals een aangepast lichtregime of de inzet van toevoegmiddelen aan mest. Het is de bedoeling dat belanghebbende partijen deze maatregelen kunnen voorstellen voor opname in bijlage 2 van de Regeling ammoniak en veehouderij (Rav), op een wijze die vergelijkbaar is met de aanvraag en opname van stalsystemen in bijlage 1 van de Rav via de Technisch adviescommissie Tac-Rav.

In strooiselstallen voor leghennen komt de meeste $\mathrm{NH}_{3}$ en fijnstof uit de (strooisel)mest (Van Harn et al, 2012). Een mogelijke oplossing om de emissie van zowel $\mathrm{NH}_{3}$ als fijnstof te reduceren is het toepassen van een dunnere strooisel-laag. In de praktijk varieert de laagdikte van het strooisel van minder dan een centimeter (begin legperiode) tot ruim $10 \mathrm{~cm}$ aan het einde van de legperiode (Van Emous et al., 2004). Pluimveehouders geven de voorkeur aan een dunne strooisel-laag (enkele cm's) omdat een dikke laag meer problemen kan geven met buitennesteieren. Het verzamelen van buitennesteieren kost erg veel tijd en ook voor de productkwaliteit zijn buitennesteieren ongewenst. Om de strooisel-laag dun te houden wordt tijdens de legperiode een gedeelte van het strooisel vanuit de gangpaden verwijderd en op de mestband geschept, waarna het strooisel wordt afgevoerd naar de mestopslag. De meeste pluimveehouders met volièrehuisvesting verwijderen tijdens de legperiode twee- tot viermaal handmatig een gedeelte van het strooisel. Enkele pluimveehouders verwijderen frequenter (minimaal vijf- tot zesmaal) het strooisel waardoor de strooisel-laag gemiddeld rond de 2 $\mathrm{cm}$ blijft. Na het verwijderen van het strooisel worden geen verse houtkrullen op de stalvloer aangebracht. De laatste jaren zijn, in het kader van arbeidsvermindering, automatische schuiven ontwikkeld om het strooisel onder de stellingen van volièresystemen frequenter te verwijderen.

Het doel van dit onderzoek is door het uitvoeren van emissiemetingen een betere inzicht te krijgen in het potentiële reducerend effect van een dunne strooisel-laag op de emissie van ammoniak, fijnstof, geur en overige broeikasgassen (methaan, lachgas). 


\section{Materiaal en methoden}

In de hierna volgende paragrafen en in de bijlagen wordt een beschrijving gegeven van de stal en de bedrijfssituatie (hoofdstuk 2.1; bijlage 1), van de metingen (hoofdstuk 2.2) en van de wijze van verwerking van de gegevens (hoofdstuk 2.3).

\section{$2.1 \quad$ Meetlocaties}

Dit onderzoek is uitgevoerd in vijf leghennenstallen op commerciële bedrijven. Hieronder volgt een beschrijving van de belangrijkste kenmerken van de gemeten stallen.

\subsubsection{Meetlocatie 1}

De metingen vonden plaats op een pluimveebedrijf in een volièrestal voor leghennen. De stal was in lengterichting in tweeën verdeeld waarbij de metingen plaatsvonden in de linkerkant van de stal (vanuit de voerruimte gezien). De rechterzijde van de stal was identiek aan de linkerzijde maar klimatologisch volledig gescheiden. De dieren in de rechterzijde van de stal hadden uitloop naar buiten terwijl de linkerzijde van de stal dit niet had. In de totale stal was plaats voor in totaal 31.200 leghennen (merk: Brown Nick) die verdeeld waren over de linker- (15.600 stuks) en rechterzijde (15.600 stuks). De dieren werden als 17-weekse leghen in de stal geplaatst en blijven daar tot aan het einde van de legperiode (ca. 80 weken leeftijd). Het begin- en eindgewicht van de dieren is naar schatting respectievelijk 1.500 en 1.900 gram. De gemeten afdeling was $12 \mathrm{~m}$ breed en $80 \mathrm{~m}$ lang en het vloeroppervlak bestond uit volledig strooisel (ook onder de volière systemen). Voor en achter in de stal was er een serviceruimte van respectievelijk 3,5 en $3 \mathrm{~m}$ diep waardoor het effectief benutbare oppervlakte voor de dieren $12 \mathrm{~m}$ breed bij 73,5 m lang was. In de stal stonden drie volièressystemen waarvan er twee een geïntegreerd legnest hadden terwijl het derde bestond uit alleen roosters.

Het strooiselmateriaal bestond bij aanvang uit $300 \mathrm{~kg}$ gehakseld koolzaadstro. De uiteindelijke leefruimte bestond uit een combinatie van strooiselvloer, roostervloer, plateaus en zitbuizen. Het leefoppervlak was $1.130 \mathrm{~cm}^{2}$ per dierplaats en bestond voor $50 \%$ uit strooiselruimte en voor $50 \%$ uit (kunststof)roostervloer.

De stal werd volledig mechanisch geventileerd waarbij de buitenlucht de stal binnenkwam via inlaatventielen aan de linkerzijde (van voren gezien) van de stal. Alle ventilatoren bevonden zich in het dak van de stal. In totaal waren er 6 ventilatoren (doorsnee van $80 \mathrm{~cm}$ ) met een capaciteit van $21.000 \mathrm{~m}^{3} /$ uur per stuk waarbij de maximaal beschikbare ventilatiecapaciteit van de stal 126.000 $\mathrm{m}^{3}$ /uur was. Omgerekend was dit $8,1 \mathrm{~m}^{3} /$ uur per hen en dus $4,3 \mathrm{~m}^{3} /$ uur per kilogram leghen (volwassen leghen: 1,9 kg). De gewenste hoeveelheid ventilatie was vooral afhankelijk van de buitentemperatuur en de streeftemperatuur was ingesteld op $20^{\circ} \mathrm{C}$.

Op de verschillende roostervloeren waren voer- en drinklijnen geplaatst. Daarbij waren de voerlijnen in het midden van de roostervloeren geplaatst terwijl de waterlijnen voor het legnest waren geplaatst. In totaal waren er 4 waterlijnen (drinknippels met lekbakjes) en 8 voerbanen (sleepketting). De voer-, water- en lichtvoorziening was volledig geautomatiseerd. Er werd 4 keer per dag voer verstrekt terwijl het water onbeperkt beschikbaar was (zie Bijlage 2 voor voersamenstelling). In de stal waren tussen 04:00 en 20:00 uur de lampen aan.

In tabel 1 worden de belangrijkste kenmerken van de stal benoemd. 


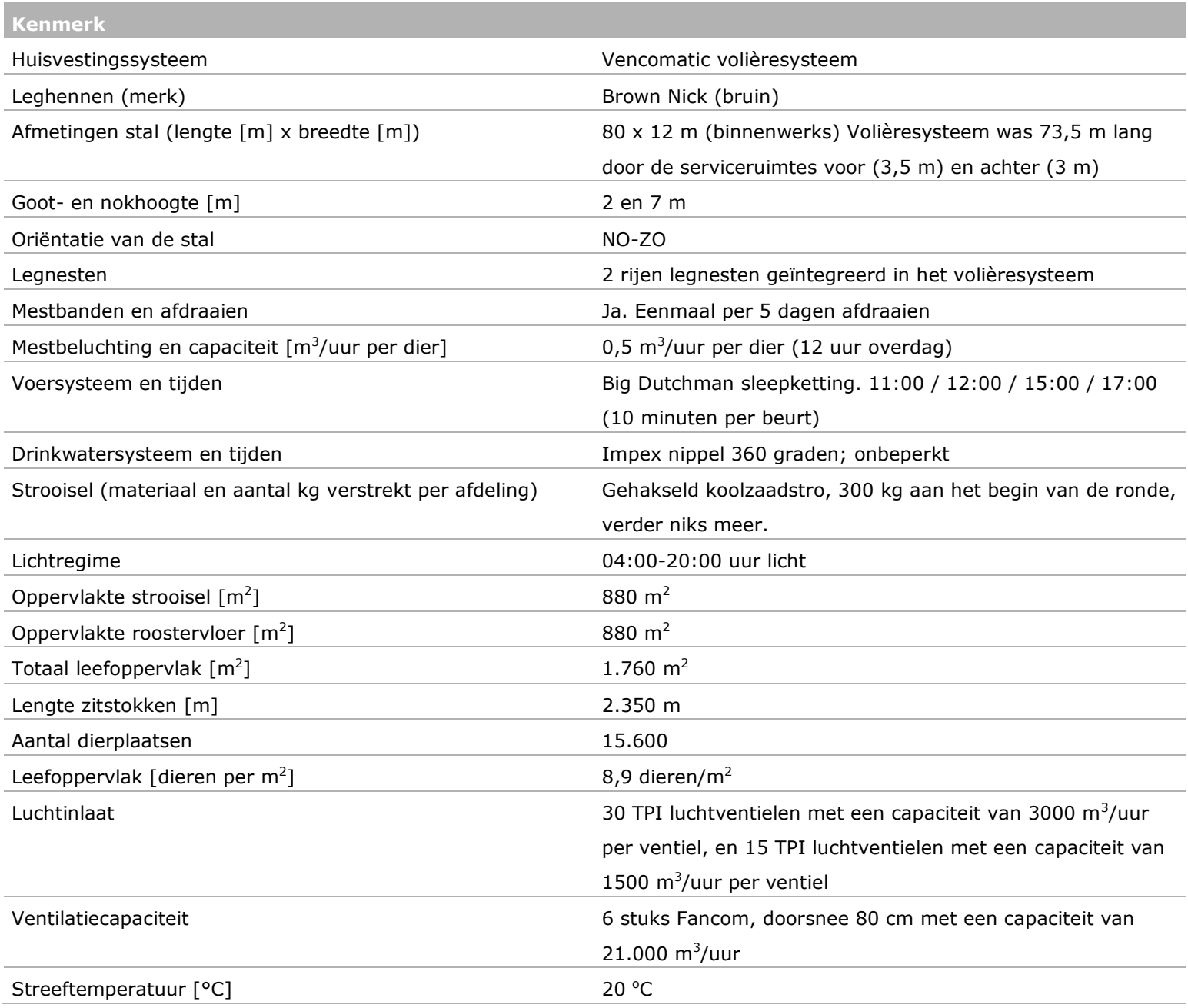




\subsubsection{Meetlocatie 2}

De metingen vonden plaats op een pluimveebedrijf in een zogenaamde twee-etage volièrestal voor leghennen. De etages waren gescheiden door een volledig dichte tussenvloer van Betonplex platen (geen luchtuitwisseling tussen de etages). De metingen vonden in de onderste etage plaats. Als huisvestingsysteem werd het Natura Floor systeem van Big Dutchman toegepast. In de stal was plaats voor in totaal 35.706 leghennen (merk: Novogen) die verdeeld waren over de onderste (17.706 stuks) en bovenste etage (18.000 stuks). De dieren werden als 18-weekse leghen in de stal geplaatst en blijven daar tot aan het einde van de legperiode (ca. 80 weken leeftijd). Het begin- en eindgewicht van de dieren is naar schatting respectievelijk 1.500 en $1.900 \mathrm{gram}$. De stal was 23,5 m breed en $79 \mathrm{~m}$ lang en het vloeroppervlak bestond uit relatief brede gangpaden (tweemaal $5 \mathrm{~m} \times 79,5$ $\mathrm{m}$ ) aan de buitenkant van de stal die bedekt waren met strooisel. Voor en achter in de stal was er een serviceruimte van respectievelijk 4 en $5 \mathrm{~m}$ diep waardoor het effectief benutbare oppervlakte voor de dieren 23,5 m breed bij 70,5 m lang was. Het middengedeelte van de stal bestond uit 2 stellingen met roosters met voer en water met legnesten in het midden van het systeem. Onder de systemen was geen strooisel onder de stellingen aanwezig.

Het strooiselmateriaal (ca. $1 \mathrm{~cm}$ ) in de gangpaden bestond bij aanvang uit luzerne. De uiteindelijke leefruimte bestond uit een combinatie van strooiselvloer, roostervloer, plateaus en zitbuizen. Het maximale leefoppervlak was $1.145 \mathrm{~cm}^{2}$ per dierplaats en bestond voor $40 \%$ uit strooiselruimte en voor $60 \%$ uit (kunststof)roostervloer.

De stal werd volledig mechanisch geventileerd (lengteventilatie) waarbij de buitenlucht de stal binnenkwam via inlaatventielen aan beiden lengtezijden van de stal. Aan éen kant staat de stal vrij, aan de andere kant grens de stal aan een andere stal voor pluimvee met wintergarten. Alle ventilatoren bevonden zich aan de achterzijden van de stal waarbij aan de buitenkant van de stal een ruimte van $5 \mathrm{~m}$ breedte bij $5 \mathrm{~m}$ lengte bij $5 \mathrm{~m}$ hoogte met damwand was gecreëerd. Hierdoor werd de ventilatielucht niet direct vanuit de stal recht achteruit geblazen maar werd de lucht via de ruimte naar boven geblazen. In totaal waren er 5 ventilatoren van twee verschillende typen per etage in de achterwand geplaatst: 3 ventilatoren met een capaciteit van $35.000 \mathrm{~m}^{3} / \mathrm{uur}$ per stuk en 2 ventilatoren met een capaciteit van $21.700 \mathrm{~m}^{3} / \mathrm{uur}$ per stuk. De maximaal beschikbare ventilatiecapaciteit van de stal was daarmee $148.400 \mathrm{~m}^{3} /$ uur. Omgerekend was dit $8,2 \mathrm{~m}^{3} / \mathrm{uur}$ per hen en dus $4,3 \mathrm{~m}^{3} / \mathrm{uur}$ per kilogram leghen (volwassen leghen: 1,9 kg). De gewenste hoeveelheid ventilatie was vooral afhankelijk van de buitentemperatuur en de streeftemperatuur was ingesteld op $21^{\circ} \mathrm{C}$.

Op de verschillende roostervloeren waren voer- en drinklijnen geplaatst. Daarbij waren de voerlijnen boven het midden van de roostervloeren geplaatst terwijl de waterlijnen aan de zijkant van het systeem was geplaatst zodat deze op ongeveer $80 \mathrm{~cm}$ vanaf het legnest was geplaatst. In totaal waren er 6 waterlijnen (drinknippels met lekbakjes) en 20 voerbanen (sleepketting) waarvan er 2 niet (boven de legnesten) waren ingeschakeld. De voer-, water- en lichtvoorziening was volledig geautomatiseerd. Er werd 4 keer per dag gevoerd verstrekt terwijl het water onbeperkt beschikbaar was (zie Bijlage 2 voor voersamenstelling). In de stal waren tussen 03:30 en 19:30 uur de lampen aan.

In tabel 2 worden de belangrijkste kenmerken van de stal benoemd. 


\section{Kenmerk}

Huisvestingssysteem

Afmetingen stal (lengte $[\mathrm{m}] \mathrm{x}$ breedte $[\mathrm{m}]$ )

Goot- en nokhoogte stal [m]

Plafondhoogte onderste etage $[\mathrm{m}]$

Oriëntatie van de stal

Legnesten
Leghennen (merk)

Natura Floor van Big Dutchman

Novogen Brown (bruin)

79,5 x 23,5 (binnenwerks). Volièresysteem was 70,5 m lang door de serviceruimtes voor $(4 \mathrm{~m})$ en achter $(5 \mathrm{~m})$

5,25 en $9,6 \mathrm{~m}$ (stal staat $0,5 \mathrm{~m}$ onder maaiveld)

$3,35 \mathrm{~m}$

NW-ZW

2 rijen volièresystemen (van ca. $6 \mathrm{~m}$ breed) met geïntegreerde legnesten

Mestbanden en afdraaien

Ja. Dagelijks de helft van de mestbanden afdraaien

Mestbeluchting en capaciteit [m3/uur per dier]

$0,7 \mathrm{~m} 3 /$ uur per dier

Voersysteem en tijden

Sleepketting. 03:25-03:45 / 09:35-10:00 / 10:25-10:45 /

$16: 20-16: 50$

Drinkwatersysteem en tijden

Drinknippel, onbeperkt

Strooisel (materiaal en aantal kg verstrekt per afdeling)

Luzerne, $105 \mathrm{~kg}$ bij aanvang ronde, daarna $15 \mathrm{~kg}$ per 4 weken

Lichtregime

03:30 tot 19:30 uur licht. Vanaf 19:05 ging het licht gefaseerd uit om de dieren in het systeem te lokken.

Oppervlakte strooisel [m2]

$795 \mathrm{~m} 2$

Oppervlakte roostervloer [m2]

$1.205 \mathrm{~m} 2$

Totaal leefoppervlak [m2]

$2.000 \mathrm{~m} 2$

Lengte zitstokken $[\mathrm{m}]$

$2.700 \mathrm{~m} 2$

Aantal dierplaatsen

17.706 stuks (onderste verdieping)

Leefoppervlak [dieren per m2]

9,0 dieren $/ \mathrm{m} 2$

Luchtinlaat

Ventielen met lamellen

Ventilatiecapaciteit

Fancom: $3 \times 35.000 \mathrm{~m} 3 / \mathrm{uur}+2 \times 21.700 \mathrm{~m} 3 / \mathrm{uur}$.

Streeftemperatuur $\left[{ }^{\circ} \mathrm{C}\right]$

21 


\subsubsection{Meetlocatie 3}

De metingen vonden plaats op een pluimveebedrijf in een zogenaamde twee-etage volièrestal voor leghennen. De etages waren gescheiden door een volledig dichte tussenvloer van Betonplex platen (geen luchtuitwisseling tussen de etages). De metingen vonden in de onderste etage plaats. Als huisvestingsysteem werden 2 rijen van het Veranda systeem (Veranda Aviary) van Vencomatic toegepast. Dit systeem is oorspronkelijk ontwikkeld als groepskooi voor leghennen maar kan ook als volièresysteem worden gebruikt wanneer de deurtjes, die zich aan de buitenkant bevinden, van het systeem worden geopend. Deze deurtjes kunnen gedurende de legperiode in het begin van de nacht gesloten worden zodat de dieren 's morgens in het systeem zitten. Dit kan gebruikt worden om buitennesteieren te voorkomen. Om de beide etages te bereiken zijn aan de zijkant van het systeem trapjes van gaas geplaatst. Aan de binnenkant van het systeem zijn per kooilaag legnesten over de gehele lengte van het systeem geplaatst. In de stal was plaats voor in totaal 22.900 leghennen (merk: LSL) die verdeeld waren over de onderste ( 11.450 stuks) en bovenste etage (11.450 stuks).

De dieren werden als 18-weekse leghen in de stal geplaatst en blijven daar tot aan het einde van de legperiode (ca. 80 weken leeftijd). Het begin- en eindgewicht van de dieren is naar schatting respectievelijk 1.350 en 1.800 gram. De stal was 13 m breed en $70 \mathrm{~m}$ lang waarbij voor- en achterin de stal een serviceruimte was gesitueerd van $4 \mathrm{~m}$ diep waarbij de netto vloeroppervlakte $13 \mathrm{~m}$ breed bij 62 m lang was.

Het vloeroppervlak bestond uit volledig strooisel. In het midden van de stal stonden twee rijen met het volièresysteem met een smalle tussengang van $60 \mathrm{~cm}$. Onder het volièresysteem is strooisel aanwezig. Het strooiselmateriaal (ca. $1 \mathrm{~cm}$ ) bestond bij aanvang uit 6 tot 7 balen gehakseld stro. De uiteindelijke leefruimte bestond uit een combinatie van strooiselvloer, roostervloer, plateaus en zitbuizen. Het leefoppervlak was $1.091 \mathrm{~cm}^{2}$ per dierplaats en bestond voor $65 \%$ uit strooiselruimte en voor $35 \%$ uit (kunststof)roostervloer.

De stal werd volledig mechanisch geventileerd waarbij de buitenlucht de stal binnenkwam via inlaatventielen aan beiden lengtezijden van de stal. In de rechterzijde van de stal bevonden zich 4 ventilatoren met een maximale capaciteit van $35.000 \mathrm{~m}^{3} / \mathrm{uur}$ (bij $0 \mathrm{~Pa}$ ) per stuk. Alle 4 ventilatoren draaiden altijd op hetzelfde niveau waarbij de eerste ventilator een meetventilator had voor de terugkoppeling van de ventilatiehoeveelheid. Er was dus in deze stal sprake van een soort van dwarsventilatie. Dit werd gedaan omdat er een droogtunnel was geplaatst naast de stal waarbij gebruik werd gemaakt van de ventilatielucht om de mest op de banden van de droogtunnel te drogen. Tijdens de metingen was deze tunnel in verband met reparatiewerkzaamheden en onderhoud niet in gebruik. Aan de achterzijde van de stal waren nog 2 ventilatoren met een maximale capaciteit van $50.000 \mathrm{~m}^{3} /$ uur (bij $0 \mathrm{~Pa}$ ) per stuk geïnstalleerd die alleen ingeschakeld werd bij hoge staltemperaturen $\left(>25^{\circ} \mathrm{C}\right)$. De maximaal beschikbare ventilatiecapaciteit van de stal kwam daarmee in totaal op $240.000 \mathrm{~m}^{3} /$ uur. In de praktijk zal dit netto ongeveer $200.000 \mathrm{~m}^{3} /$ uur opleveren aan maximale capaciteit. De gewenste hoeveelheid ventilatie was vooral afhankelijk van de buitentemperatuur en de streeftemperatuur was ingesteld op $20^{\circ} \mathrm{C}$.

Op de verschillende roostervloeren waren voer- en drinklijnen geplaatst. Per rooster waren 2 voerlijnen en 1 waterlijn (voor het legnest) gesitueerd. In totaal waren er 4 waterlijnen (drinknippels met lekbakjes) en 8 voerbanen (sleepketting). De voer-, water- en lichtvoorziening was volledig geautomatiseerd. Er werd 4 keer per dag gevoerd (zie bijlage 2 voor voersamenstelling). Het water was onbeperkt beschikbaar. In de stal waren tussen 05:00 en 18:30 uur de lampen aan.

In tabel 3 worden de belangrijkste kenmerken van de stal benoemd. 


\section{Kenmerk}

Huisvestingssysteem

Leghennen (merk)

Afmetingen stal (lengte $[\mathrm{m}] \times \mathrm{x}$ breedte $[\mathrm{m}]$ )
Veranda Aviary van Vencomatic

Lohman LSL (wit)

$70 \times 13$ m (binnenwerks). Volièresysteem was $62 \mathrm{~m}$ lang door de serviceruimtes voor en achter (elk $4 \mathrm{~m}$ ) en $11 \mathrm{~m}$ breed.

2 en $7 \mathrm{~m}$

$2,6 \mathrm{~m}$

$\mathrm{W}-\mathrm{O}$

Per etage van het volièresysteem was een rij legnesten geplaatst. Dus in totaal 4 rijen.

Mestbanden en afdraaien Normaal driemaal daags i.v.m. droogtunnel. Die was tijdens de metingen niet in bedrijf. Daarom werd tijdens de metingen alleen op zaterdag afgedraaid.

Mestbeluchting en capaciteit [ $\mathrm{m}^{3} /$ uur per dier] Mest op de banden werd belucht met $0,2 \mathrm{~m}^{3} / \mathrm{uur}$ per dier. Voersysteem en tijden Sleepketting. 07:30 / 11:25 / 12:25 / 16:00. Er zijn 10 voerlijnen aanwezig. Drinknippels, onbeperkt

Drinkwatersysteem en tijden 6 tot 7 balen gehakseld stro bij aanvang van de koppel. Daarna per 6-8 weken weer aanvullen.

\begin{tabular}{l}
\hline Lichtregime \\
\hline Oppervlakte strooisel $\left[\mathrm{m}^{2}\right]$ \\
\hline Oppervlakte roostervloer $\left[\mathrm{m}^{2}\right]$ \\
\hline Totaal leefoppervlak $\left[\mathrm{m}^{2}\right]$ \\
\hline Lengte zitstokken $[\mathrm{m}]$ \\
\hline Aantal dierplaatsen \\
\hline Leefoppervlak $\left[\right.$ dieren per $\left.\mathrm{m}^{2}\right]$ \\
\hline Luchtinlaat \\
\hline Ventilatiecapaciteit
\end{tabular}

Streeftemperatuur $\left[{ }^{\circ} \mathrm{C}\right]$
05:00-18:30 uur licht

$806 \mathrm{~m}^{2}$

$444 \mathrm{~m}^{2}$

$1.250 \mathrm{~m}^{2}$

$1.740 \mathrm{~m}$

11.450 stuks per etage, 22.900 stuks totaal

9,2 dieren $/ \mathrm{m}^{2}$

Inlaatventielen aan beide kanten van de stal

4 ventilatoren in de rechter zijwand ( $35.000 \mathrm{~m}^{3} / \mathrm{uur}$ ). In de achterwand 2 ventilatoren met ( $50.000 \mathrm{~m}^{3} / \mathrm{uur}$ ). 


\subsubsection{Meetlocatie 4}

De metingen vonden plaats op een pluimveebedrijf in een zogenaamde twee-etage volièrestal voor leghennen. De etages waren gescheiden door een volledig dichte tussenvloer van Betonplex platen (geen luchtuitwisseling tussen de etages). De metingen vonden in de onderste etage plaats. Als huisvestingsysteem was een volièresysteem van Farmer Automatic geïnstalleerd. De stal bestond uit twee relatief brede gangpaden aan beide zijden van de stal met 2 volièresystemen met geïntegreerde legnesten. In het midden van de stal was een legnest geplaatst met aan beide zijden een roostervloer vlak boven de grond met mestbanden onder het rooster (een soort scharrelopstelling) en boven het rooster was links en rechts van het midden (legnest) een volièrestelling geplaatst. In de stal was plaats voor in totaal 47.800 leghennen (merk: Novogen bruin) die verdeeld waren over de onderste (23.900 stuks) en bovenste etage (23.900 stuks). De dieren werden als 18-weekse leghen in de stal geplaatst en blijven daar tot aan het einde van de legperiode (ca. 80 weken leeftijd). Het begin- en eindgewicht van de dieren is naar schatting respectievelijk 1.500 en 1.900 gram. De stal was $21,5 \mathrm{~m}$ breed en $100 \mathrm{~m}$ lang waarbij voor en achterin de stal een serviceruimte was gesitueerd van elk 3,5 m diep waardoor de netto vloeroppervlakte $21,5 \mathrm{~m}$ breed bij 93 m lang was.

Het vloeroppervlak bestond voor $77 \%$ uit strooisel. Onder de buitenste volièresystemen was dus strooisel aanwezig. Het strooiselmateriaal (ca. $1 \mathrm{~cm}$ ) bestond bij aanvang uit gehakseld stro. De uiteindelijke leefruimte bestond uit een combinatie van strooiselvloer, roostervloer, plateaus en zitbuizen. Het leefoppervlak was $1.120 \mathrm{~cm}^{2}$ per dierplaats en bestond voor $58 \%$ uit strooiselruimte en voor $42 \%$ uit (kunststof)roostervloer.

De stal werd volledig mechanisch geventileerd waarbij de buitenlucht de stal binnenkwam via inlaatventielen aan beiden lengtezijden van de stal (20 stuks per zijde). In de rechterzijde van de stal bevond zich 1 ventilator met een maximale capaciteit van $30.000 \mathrm{~m}^{3} / \mathrm{uur}$ die continue stallucht naar de droogtunnel blies. Aan de achterzijde van de stal waren 4 ventilatoren met een maximale capaciteit van $40.000 \mathrm{~m}^{3} /$ uur per stuk geïnstalleerd die via een cascade regeling werden ingeschakeld. Dit betekent dat de ventilatoren achter elkaar werden ingeschakeld afhankelijk van de ventilatiebehoefte. Daarnaast werden de ventilatoren niet via een vaste volgorde ingeschakeld maar werd dit willekeurig gedaan. De maximaal beschikbare ventilatiecapaciteit van de stal was totaal $190.000 \mathrm{~m}^{3} / \mathrm{uur}$. Omgerekend was dit 7,9 $\mathrm{m}^{3} / \mathrm{uur}$ per hen en dus $4,2 \mathrm{~m}^{3} /$ uur per kilogram leghen (volwassen leghen van $1,9 \mathrm{~kg}$ ). De gewenste hoeveelheid ventilatie was vooral afhankelijk van de buitentemperatuur en de streeftemperatuur was ingesteld op $19,5^{\circ} \mathrm{C}$.

Op alle roostervloeren was 1 voerlijn (sleepketting) en dus 2 voerbanen gesitueerd en voor de gehele stal betekende dit dat er 14 voerbanen waren. Voor de legnesten was het watersysteem geïnstalleerd (drinknippels met lekbakjes) waardoor er 6 waterlijnen waren. De voer-, water- en lichtvoorziening was volledig geautomatiseerd. Er werd 5 keer per dag gevoerd (zie bijlage 2 voor voersamenstelling). Het water was onbeperkt beschikbaar. In de stal waren tussen 04:30 en 19:00 uur de lampen aan.

In tabel 4 worden de belangrijkste kenmerken van de stal benoemd. 


\begin{tabular}{|c|c|}
\hline \multicolumn{2}{|l|}{ Kenmerk } \\
\hline Huisvestingssysteem & Farmer Automatic volièresysteem \\
\hline Leghennen (merk) & Novogen Brown (bruin) \\
\hline Afmetingen stal (lengte $[\mathrm{m}] \times$ breedte $[\mathrm{m}]$ ) & $\begin{array}{l}100 \times 21,5 \mathrm{~m} \text { (binnenwerks). Volièresysteem was } 93 \text { m } \\
\text { lang door de serviceruimtes voor en achter (elk 3,5 m) }\end{array}$ \\
\hline Goot- en nokhoogte stal [m] & $4,2 \mathrm{~m}$ en $9,0 \mathrm{~m}$ \\
\hline Oriëntatie van de stal & $\mathrm{N}-\mathrm{Z}$ \\
\hline Legnesten & $\begin{array}{l}\text { Per volièresysteem en in het midden van de stal was een } \\
\text { rij legnesten geplaatst. Dus in totaal } 3 \text { rijen. }\end{array}$ \\
\hline Mestbanden en afdraaien & Tweemaal daags i.v.m. droogtunnel (ochtend en middag) \\
\hline Drinkwatersysteem en tijden & Drinknippels voor legnest, onbeperkt \\
\hline Strooisel (materiaal en aantal kg verstrekt per afdeling) & $\begin{array}{l}\text { Gehakseld stro ( } 40 \mathrm{~kg} \text { per } 1000 \text { kippen aan het begin van } \\
\text { de ronde) }\end{array}$ \\
\hline Lichtregime & 04:30-19:30 uur licht \\
\hline Oppervlakte strooisel $\left[\mathrm{m}^{2}\right]$ & $1.545 \mathrm{~m}^{2}$ \\
\hline Oppervlakte roostervloer $\left[\mathrm{m}^{2}\right]$ & $1.125 \mathrm{~m}^{2}$ \\
\hline Totaal leefoppervlak $\left[\mathrm{m}^{2}\right]$ & $2.670 \mathrm{~m}^{2}$ \\
\hline Lengte zitstokken $[\mathrm{m}]$ & $3.600 \mathrm{~m}$ \\
\hline Streeftemperatuur $\left[{ }^{\circ} \mathrm{C}\right]$ & 19,5 \\
\hline
\end{tabular}




\subsubsection{Meetlocatie 5}

De metingen vonden plaats op een pluimveebedrijf met meerdere stallen voor leghennen. Als huisvestingsysteem in de gemeten stal was een volièresysteem van Big Dutchman (Natura Colony) geïnstalleerd. De stal bestond uit twee relatief brede $(1,8 \mathrm{~m})$ gangpaden aan beide buitenzijden van de stal met 2 volièresystemen met geïntegreerde legnesten. In het midden van de stal tussen de volièresystemen was een gang van $1,4 \mathrm{~m}$ breed. In de stal was plaats voor in totaal 9036 leghennen (merk: Brown Nick bruin). De dieren werden als 18-weekse leghen (6 oktober 2014) in de stal geplaatst en blijven daar tot aan het einde van de legperiode 23 juni 2016 . Het begin- en eindgewicht van de dieren is naar schatting respectievelijk 1.500 en 1.950 gram. De stal was 9,9 m breed en $55 \mathrm{~m}$ lang waarbij voor en achterin de stal een serviceruimte was gesitueerd van 1,8 en2,5 m diep waardoor de netto vloeroppervlakte $502 \mathrm{~m}^{2}$ bedroeg $(9,9 \mathrm{~m}$ bij 50,7 m).

Het vloeroppervlak bestond voor $100 \%$ uit strooisel. Het strooiselmateriaal (ca. $1 \mathrm{~cm}$ ) bestond bij aanvang uit houtkrullen. De uiteindelijke leefruimte bestond uit een combinatie van strooiselvloer, roostervloer, plateaus en zitbuizen. Het leefoppervlak was $1.120 \mathrm{~cm}^{2}$ per dierplaats en bestond voor $58 \%$ uit strooiselruimte en voor $42 \%$ uit (kunststof)roostervloer. De mest werd met behulp van mestbanden minimaal 1 keer per 5 dagen uit de stal verwijderd.

De stal werd volledig mechanisch geventileerd waarbij de buitenlucht de stal binnenkwam via inlaatventielen aan de noordzijde van de stal. In de zuidzijde van de stal (ongeveer op de helft van de lengte van de stal) bevonden zich 2 ventilatoren met een maximale capaciteit van $41.000 \mathrm{~m}^{3} / \mathrm{uur}$ die continue stallucht naar buiten blies. De maximaal beschikbare ventilatiecapaciteit van de stal was totaal $82.000 \mathrm{~m}^{3} /$ uur. Omgerekend was dit 7,9 $\mathrm{m}^{3} / \mathrm{uur}$ per hen en dus 4,2 $\mathrm{m}^{3} /$ uur per kilogram leghen (volwassen leghen van 1,9 kg). De gewenste hoeveelheid ventilatie was vooral afhankelijk van de buitentemperatuur en de streeftemperatuur was ingesteld op $20,0^{\circ} \mathrm{C}$.

Per stelling waren 5 voerlijnen en 3 waterlijnen (drinknippels met lekbakjes) geïnstalleerd. De voer-, water- en lichtvoorziening was volledig geautomatiseerd. Er werd 5 keer per dag gevoerd (zie bijlage 2 voor voersamenstelling). Het water was onbeperkt beschikbaar. In de stal waren tussen 04:00 en 20:00 uur de lampen aan.

In tabel 5 worden de belangrijkste kenmerken van de stal benoemd. 


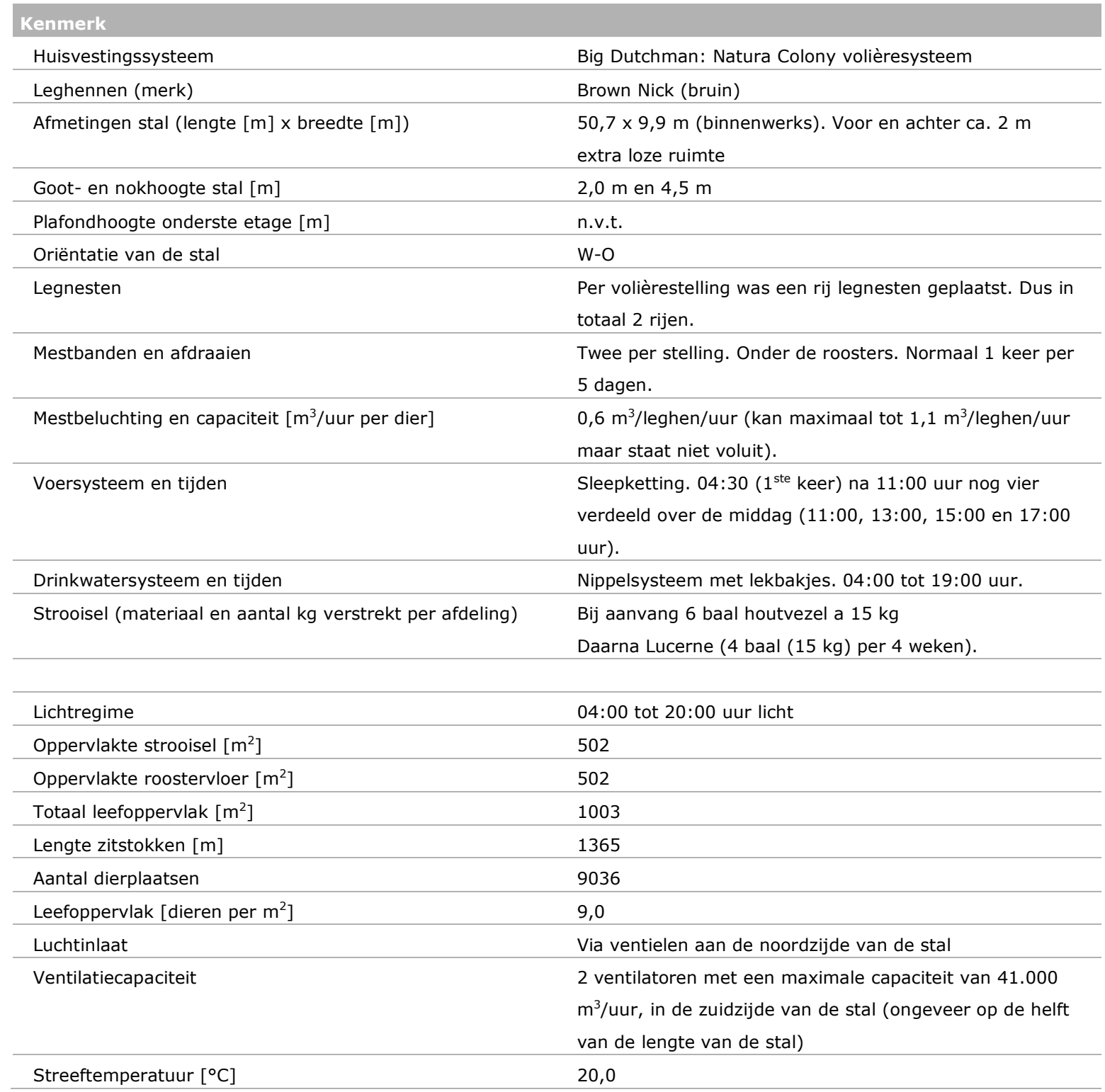




\subsection{Metingen}

In dit onderzoek zijn in alle onderzochte stallen waarnemingen verricht aan ammoniak $\left(\mathrm{NH}_{3}\right)$, geur, overige broeikasgassen (methaan $\left(\mathrm{CH}_{4}\right)$ en lachgas $\left(\mathrm{N}_{2} \mathrm{O}\right)$ ), fijnstof (PM10), ventilatiedebiet, temperatuur, relatieve luchtvochtigheid, dikte strooisel-laag. Tevens zijn de technische resultaten van de hennen vastgelegd. Wat betreft de meetstrategie is bij de emissiemetingen voor ammoniak $\left(\mathrm{NH}_{3}\right)$, geur, fijn stof $(\mathrm{PM10})$, methaan $\left(\mathrm{CH}_{4}\right)$ en lachgas $\left(\mathrm{N}_{2} \mathrm{O}\right)$ zoveel mogelijk aangesloten bij de protocollen zoals beschreven in respectievelijk Ogink e.a. (2014), Ogink (2011), Ogink e.a. (2011), Groenestein e.a. (2011) en Mosquera e.a. (2011). Om redenen die hierna worden toegelicht zijn de metingen in drie series uitgevoerd. Bij de eerste serie metingen zijn alleen $\mathrm{NH}_{3}$ en PM10 gemeten, bij de andere twee series zijn ook geur- en broeikasgas-emissiemetingen uitgevoerd. Daarnaast is voor het meten van PM10 een andere meetmethode toegepast (zie 2.2.2).

De metingen zijn uitgevoerd volgens het zogenaamde 'case-control in de tijd' strategie binnen dezelfde stal. Aan het begin van een meetperiode werd een 24-uursmeting verricht in de stal zoals aangetroffen, d.w.z. met een dikke strooisel-laag (controlemeting). Daarna werd een deel van de strooisel uit de stal verwijderd, en na een periode van 2-3 dagen een tweede 24-uursmeting uitgevoerd in de stal met een dunne strooisel-laag (proefmeting). Door de uitbraak van vogelpest eind 2014 moest de planning van de metingen worden aangepast, waardoor een aantal metingen in 2015 uitgevoerd moest worden. Bij meetlocatie 1 en 3 is begin 2015 een schuifsysteem geplaatst, waardoor bij deze twee meetlocaties alleen twee in plaats van de ingeplande drie metingen konden worden uitgevoerd. Daarom is er voor gekozen om aanvullend op een vijfde locatie metingen uit te voeren. Deze metingen zijn in het najaar van 2015, het voorjaar van 2016 en de zomer van 2016 uitgevoerd.

\subsubsection{Meetpunten}

\section{Meetlocatie 1}

Op deze locatie komt de lucht naar binnen door inlaatventielen verdeeld over de lange zijde aan beide kanten van de stal (zie hoofdstuk 2.1). De $\mathrm{NH}_{3}$-achtergrondconcentratie werd aan één kant van de stal in duplo (nat-chemisch; zie hoofdstuk 2.2.2) gemeten. De achtergrondconcentratie voor PM10 werd aan één kant van de stal (in enkelvoud met een optisch instrument bij de eerste series metingen, in duplo gravimetrisch bij de tweede series metingen; zie hoofdstuk 2.2.2) gemeten. De achtergrondconcentratie voor $\mathrm{CH}_{4}, \mathrm{~N}_{2} \mathrm{O}$ en $\mathrm{CO}_{2}$ werd aan één kant van de stal in enkelvoud met de longmethode gemeten. Daarnaast werd de $\mathrm{CO}_{2}$-concentratie ook in enkelvoud met een fotoakoestische monitor (zie hoofdstuk 2.2.2) gemeten. Voor geur werden geen achtergrondconcentraties gemeten, aangezien geuremissies niet voor achtergrondconcentraties kunnen worden gecorrigeerd. Aan dezelfde kant van de stal werd ook de temperatuur en relatieve luchtvochtigheid van de buitenlucht gemeten (zie hoofdstuk 2.2.2).

De stal wordt door middel van zes nok-ventilatoren geventileerd (zie hoofdstuk 2.1). De concentratie van de uitgaande stallucht werd gedurende series 1 op twee meetpunten (bij kokers 3 en 4, midden in de stal) gemeten. Aangezien de gemeten concentraties bij beide kokers vergelijkbaar waren, is het voor de tweede series metingen gekozen om alleen bij een van de kokers (koker 3 ) te meten. Voor $\mathrm{NH}_{3}$ werd op de gekozen meetpunten de stalconcentratie in duplo nat-chemisch gemeten (zie hoofdstuk 2.2.2). Voor PM10 werd op de gekozen meetpunten de stalconcentratie tijdens de eerste serie metingen in enkelvoud met een optisch instrument gemeten, en tijdens de tweede serie metingen gravimetrisch (zie hoofdstuk 2.2.2) gemeten. Tijdens meetserie 1 werd de $\mathrm{CO}_{2-}$ stalconcentratie bij een van de kokers (koker 4 ) in duplo gemeten (longmethode; zie hoofdstuk 2.2.2), bij de andere koker (koker 3 ) in enkelvoud met de longmethode, en in enkelvoud met een fotoakoestische monitor (zie hoofdstuk 2.2.2) gemeten. Tijdens meetserie 2 werd de geur-, $\mathrm{CH}_{4^{-}}$, $\mathrm{N}_{2} \mathrm{O}$-stalconcentratie bij alleen een van de kokers (koker 3 ) in duplo gemeten. $\mathrm{CO}_{2}$ werd of in duplo (longmethode), of in enkelvoud met zowel de longmethode en een fotoakoestische monitor gemeten. 
Bij de gekozen meetpunten werd ook de temperatuur en relatieve luchtvochtigheid van de stallucht gemeten (zie hoofdstuk 2.2.2).

De dikte van de strooisellaag werd voorafgaand aan de metingen op twintig verschillende plaatsen in de stal gemeten: tien op de gangpad, en tien op de roostergedeelten (zie hoofdstuk 2.2.2). Op deze plekken werd een strooiselmonster genomen, en gemengd om twee mengmonsters te maken, één voor de gangpad, en één voor de roostergedeelten.

\section{Meetlocatie 2}

Op deze locatie komt de lucht naar binnen door inlaatventielen verdeeld over de lange zijde aan beide kanten van de stal (zie hoofdstuk 2.1). Aan één kant staat de stal vrij (weiland), aan de andere kant grenst de stal aan een andere stal voor pluimvee met wintergarten. Om deze reden is er voor gekozen om aan beide kanten van de stal 1 meetpunt te plaatsen (op ongeveer $1 / 3$ van de lengte van de stal gerekend vanaf de voorkant van de stal) om de achtergrondconcentratie te meten. $\mathrm{De} \mathrm{NH}_{3}$ achtergrondconcentratie werd aan beide zijden in duplo (nat-chemisch; zie hoofdstuk 2.2.2) gemeten. De achtergrondconcentratie voor PM10 werd aan beide kanten van de stal tijdens meetserie 1 in enkelvoud met een optisch instrument en tijdens meetserie 2 en 3 in duplo gravimetrisch (zie hoofdstuk 2.2.2) gemeten. De achtergrondconcentratie voor $\mathrm{CO}_{2}, \mathrm{CH}_{4}$ en $\mathrm{N}_{2} \mathrm{O}\left(\mathrm{CH}_{4}\right.$ en $\mathrm{N}_{2} \mathrm{O}$ alleen bij meetserie 2 en 3) werd aan beide zijden in enkelvoud (longmethode; zie hoofdstuk 2.2.2) gemeten. Aan de kant van de stal die grenst aan een andere stal werd een extra $\mathrm{CO}_{2}$-concentratiemeting uitgevoerd met behulp van een fotoakoestische monitor (zie hoofdstuk 2.2.2). Voor geur werden geen achtergrondconcentraties gemeten, aangezien geuremissies niet voor achtergrondconcentraties kunnen worden gecorrigeerd. Aan deze kant van de stal werd ook de temperatuur en relatieve luchtvochtigheid van de buitenlucht gemeten (zie hoofdstuk 2.2.2).

De stal wordt door middel van vijf ventilatoren (drie grotere onder en twee kleinere boven) in de lengte geventileerd (zie hoofdstuk 2.1). De concentratie van de uitgaande stallucht werd op twee meetpunten (één vóór een grote ventilator, en één vóór een kleine ventilator) gemeten. Voor $\mathrm{NH}_{3}$ werd op beide meetpunten de stalconcentratie in enkelvoud nat-chemisch gemeten (zie hoofdstuk 2.2.2). Voor PM10 werd op beide meetpunten de stalconcentratie tijdens meetserie 1 in enkelvoud met een optisch instrument en tijdens meetserie 2 en 3 in enkelvoud gravimetrisch (zie hoofdstuk 2.2.2) gemeten. Voor geur, $\mathrm{CH}_{4}, \mathrm{~N}_{2} \mathrm{O}$ (tijdens meetserie 2 en 3) en $\mathrm{CO}_{2}$ (alle drie meetseries) werd op beide meetpunten de stalconcentratie in enkelvoud gemeten (longmethode; zie hoofdstuk 2.2.2). Op de meetpunt bij de grote ventilator werd de $\mathrm{CO}_{2}$ concentratie ook met een fotoakoestische monitor (zie hoofdstuk 2.2.2) gemeten. Bij deze ventilator werd ook de temperatuur en relatieve luchtvochtigheid van de stallucht gemeten (zie hoofdstuk 2.2.2).

De dikte van de strooisellaag werd voorafgaand aan de metingen op twintig verschillende plaatsen in de stal gemeten: tien op de gangpad, en tien op de roostergedeelten (zie hoofdstuk 2.2.2). Op deze plekken werd een strooiselmonster genomen, en gemengd om twee mengmonsters te maken, één voor de gangpad, en één voor de roostergedeelten.

\section{Meetlocatie 3}

Op deze locatie komt de lucht naar binnen door inlaatventielen verdeeld over de lange zijde aan beide kanten van de stal (zie hoofdstuk 2.1). Aan beide kanten grenst de stal aan een andere stal voor pluimvee. Echter, een van deze kanten is meestal dicht. De $\mathrm{NH}_{3}$-achtergrondconcentratie werd daardoor aan één kant van de stal (bij de inlaatopeningen dicht bij de meetpunten voor de uitgaande stallucht, maar aan de buitenkant van de stal) in duplo (nat-chemisch; zie hoofdstuk 2.2.2) gemeten. De achtergrondconcentratie voor PM10 werd op één meetpunt aan één kant van de stal in enkelvoud met een optisch instrument (zie hoofdstuk 2.2.2) gemeten. De achtergrondconcentratie voor $\mathrm{CO}_{2}, \mathrm{CH}_{4}$ en $\mathrm{N}_{2} \mathrm{O}\left(\mathrm{CH}_{4}\right.$ en $\mathrm{N}_{2} \mathrm{O}$ alleen bij meetserie 2 en 3 ) werd in enkelvoud met de longmethode gemeten. De $\mathrm{CO}_{2}$-concentratie werd ook in enkelvoud met een fotoakoestische monitor gemeten (zie hoofdstuk 2.2.2). Voor geur werden geen achtergrondconcentraties gemeten, aangezien geuremissies niet voor achtergrondconcentraties kunnen worden gecorrigeerd. De temperatuur en relatieve luchtvochtigheid van de buitenlucht werd op een meetpunt aan een kant van de stal gemeten (zie hoofdstuk 2.2.2). 
De stal wordt door middel van vier ventilatoren in een van de zijwanden geventileerd. Daarnaast zijn er twee ventilatoren in de achterwand die gebruik worden voor heel warm weer (zie hoofdstuk 2.1). Tijdens de metingen waren deze ventilatoren niet in gebruik. De concentratie van de uitgaande stallucht werd op twee meetpunten (bij koker 1 en bij koker 3; zie hoofdstuk 2.1) gemeten. Voor $\mathrm{NH}_{3}$ werd op beide meetpunten de stalconcentratie in duplo nat-chemisch gemeten (zie hoofdstuk 2.2.2). Voor PM10 werd op beide meetpunten de stalconcentratie tijdens meetserie 1 in enkelvoud met een optisch instrument, en tijdens meetserie $23 \mathrm{n} 3$ in duplo gravimetrisch (zie hoofdstuk 2.2.2) gemeten. Voor geur, $\mathrm{CH}_{4}, \mathrm{~N}_{2} \mathrm{O}$ (tijdens meetserie 2 en 3) en $\mathrm{CO}_{2}$ (alle drie meetseries) werd bij koker 3 de stalconcentratie in enkelvoud met de longmethode gemeten. Bij koker 1 werd de geur-, $\mathrm{CH}_{4}{ }^{-}, \mathrm{N}_{2} \mathrm{O}-$ en $\mathrm{CO}_{2}$-concentratie in enkelvoud met de longmethode gemeten (geur, $\mathrm{CH}_{4}$ en $\mathrm{N}_{2} \mathrm{O}$ alleen bij meetserie 2 en 3). Daarnaast werd de $\mathrm{CO}_{2}$-concentratie ook in enkelvoud met een fotoakoestische monitor gemeten (zie hoofdstuk 2.2.2). Bij deze koker werd ook de temperatuur en relatieve luchtvochtigheid van de stallucht gemeten (zie hoofdstuk 2.2.2).

De dikte van de strooisellaag werd voorafgaand aan de metingen op twintig verschillende plaatsen in de stal gemeten: tien op de gangpad, en tien op de roostergedeelten (zie hoofdstuk 2.2.2). Op deze plekken werd een strooiselmonster genomen, en gemengd om twee mengmonsters te maken, één voor de gangpad, en één voor de roostergedeelten.

\section{Meetlocatie 4}

Op deze locatie komt de lucht naar binnen door inlaatventielen verdeeld over de lange zijde aan beide kanten van de stal (zie hoofdstuk 2.1). Aan beide kanten grenst de stal aan een andere stal voor pluimvee. Aan een kant van de stal is een droogtunnel geplaatst. Aan die kant van de stal werd de $\mathrm{NH}_{3}$-achtergrondconcentratie vlakbij de droogtunnel in duplo gemeten (nat-chemisch; zie hoofdstuk 2.2.2). De $\mathrm{CH}_{4}{ }^{-}, \mathrm{N}_{2} \mathrm{O}$ - en $\mathrm{CO}_{2}$-concentratie werd aan deze kant van de stal in enkelvoud met de longmethode gemeten $\left(\mathrm{CH}_{4}\right.$ en $\mathrm{N}_{2} \mathrm{O}$ alleen tijdens meetserie 2 en 3). $\mathrm{CO}_{2}$ werd ook in enkelvoud met een fotoakoestische monitor gemeten (zie hoofdstuk 2.2.2). De PM10-achtergrondsconcentratie werd in enkelvoud met een optisch instrument (zie hoofdstuk 2.2.2) gemeten. Voor geur werden geen achtergrondconcentraties gemeten, aangezien geuremissies niet voor achtergrondconcentraties kunnen worden gecorrigeerd.

Aan de andere kant van de stal werd de $\mathrm{NH}_{3}$-achtergrondconcentratie in duplo gemeten (natchemisch; zie hoofdstuk 2.2.2). De $\mathrm{CH}_{4}{ }^{-}, \mathrm{N}_{2} \mathrm{O}$ - en $\mathrm{CO}_{2}$-concentratie werd aan deze kant van de stal ook in duplo gemeten (longmethode; zie hoofdstuk 2.2.2; $\mathrm{CH}_{4}$ en $\mathrm{N}_{2} \mathrm{O}$ alleen tijdens meetserie 2 en 3). Voor PM10 werd de achtergrondconcentratie in enkelvoud met een optisch instrument (zie hoofdstuk 2.2.2) gemeten. De temperatuur en relatieve luchtvochtigheid van de buitenlucht werd buiten de stal aan de achterkant van de stal gemeten.

De stal wordt door middel van drie ventilatoren in een van de zijwanden (vóór de droogtunnel, aan de achterkant van de stal) en vier ventilatoren (aan de achterkant van de stal) geventileerd (zie hoofdstuk 2.1). De concentratie van de uitgaande stallucht werd op één meetpunt (bij één van de kokers vóór de droogtunnel; zie hoofdstuk 2.1) gemeten. Voor $\mathrm{NH}_{3}$ werd de stalconcentratie in duplo nat-chemisch gemeten (zie hoofdstuk 2.2.2). Voor PM10 werd de stalconcentratie tijdens meetserie 1 in enkelvoud met een optisch instrument en tijdens meetserie 2 en 3 in duplo gravimetrisch (zie hoofdstuk 2.2.2) gemeten. Tijdens meetserie 1 werd de $\mathrm{CO}_{2}$-stalconcentratie in enkelvoud met de longmethode en in enkelvoud met een fotoakoestische monitor gemeten (zie hoofdstuk 2.2.2). Tijdens meetserie 2 en 3 werden de geur-, $\mathrm{CH}_{4}{ }^{-}, \mathrm{N}_{2} \mathrm{O}$ - en $\mathrm{CO}_{2}$-stalconcentraties in duplo met de longmethode gemeten. Hier werd ook de temperatuur en relatieve luchtvochtigheid van de stallucht gemeten (zie hoofdstuk 2.2.2).

De dikte van de strooisellaag werd voorafgaande aan de metingen op twintig verschillende plaatsen in de stal gemeten: tien op de gangpad, en tien op de roostergedeelten (zie hoofdstuk 2.2.2). Op deze plekken werd een strooiselmonster genomen, en gemengd om twee mengmonsters te maken, één voor de gangpad, en één voor de roostergedeelten. 


\section{Meetlocatie 5}

Op deze locatie komt de lucht naar binnen door inlaatventielen verdeeld over de noordzijde van de stal (zie hoofdstuk 2.1). Aan die kant van de stal werd de $\mathrm{NH}_{3}$-achtergrondconcentratie in duplo gemeten (nat-chemisch; zie hoofdstuk 2.2.2). De $\mathrm{CH}_{4}-, \mathrm{N}_{2} \mathrm{O}$ - en $\mathrm{CO}_{2}$-concentratie werd aan deze kant van de stal in duplo met de longmethode gemeten. De PM10-achtergrondsconcentratie werd in duplo gravimetrisch (zie hoofdstuk 2.2.2) gemeten. Voor geur werden geen achtergrondconcentraties gemeten, aangezien geuremissies niet voor achtergrondconcentraties kunnen worden gecorrigeerd.

De stal wordt door middel van twee ventilatoren in een van de zijwanden (midden in de stal) geventileerd (zie hoofdstuk 2.1). De concentratie van de uitgaande stallucht werd op beide ventilatiekokers gemeten. Voor zowel $\mathrm{NH}_{3}, \mathrm{PM} 10$, geur, $\mathrm{CO}_{2}, \mathrm{CH}_{4}$ en $\mathrm{N}_{2} \mathrm{O}$ werd per meetpunt (ventilatiekoker) de stalconcentratie in enkelvoud (duplo-meting, aangezien beide ventilatoren dicht bij elkaar zitten) gemeten. Voor $\mathrm{NH}_{3}$ werd de nat-chemische methode (zie hoofdstuk 2.2.2) toegepast, PM10 werd gravimetrisch (zie hoofdstuk 2.2.2) gemeten. Geur, $\mathrm{CH}_{4}, \mathrm{~N}_{2} \mathrm{O}$ en $\mathrm{CO}_{2}$ werden met behulp van de longmethode (zie hoofdstuk 2.2.2) gemeten. Hier werd ook de temperatuur en relatieve luchtvochtigheid van de stallucht gemeten (zie hoofdstuk 2.2.2).

De dikte van de strooisellaag werd voorafgaand aan de metingen op vijfentwintig verschillende plaatsen in de stal gemeten: vijftien op de gangpad, en tien onder de stellingen (zie hoofdstuk 2.2.2). Op deze plekken werd een strooiselmonster genomen, en gemengd om twee mengmonsters te maken, één voor de gangpad, en één voor de roostergedeelten.

\subsubsection{Meetapparatuur}

\section{Nat-chemisch $\left(\mathrm{NH}_{3}\right)$}

Bij deze methode (Wintjes, 1993) wordt lucht via een monsternameleiding met een constante luchtstroom $(\sim 1,0 \mathrm{l} / \mathrm{min})$ aangezogen met behulp van een pomp (Thomas Industries Inc., model 607CD32, Wabasha, Minnesota ,VS) en een kritische capillair die een luchtstroom geeft van $\sim 1,0$ $\mathrm{l} / \mathrm{min}$. Alle lucht wordt door een impinger (geplaatst in een wasfles met $100 \mathrm{ml} 0,05 \mathrm{M}$ salpeterzuur) geleid, waarbij de $\mathrm{NH}_{3}$ wordt opgevangen. Om rekening te houden met eventuele doorslag wordt een tweede fles in serie geplaatst. Om doorslag naar de pomp te voorkomen wordt de lucht na de impingers met zuur door een vochtvanger (impinger zonder vloeistof) geleid (Figuur 1). Na de bemonsteringstijd wordt de concentratie gebonden $\mathrm{NH}_{3}$ spectrofotometrisch bepaald. Voor en na de meting werd de exacte luchtstroom bepaald met behulp van een flowmeter (Defender 510-m, Bios Int. Corp, USA). Door de bemonsteringsduur, de bemonsteringsflow, het $\mathrm{NH}_{4}{ }^{+}$gehalte en de hoeveelheid opvangvloeistof te verrekenen kan de $\mathrm{NH}_{3}$-concentratie in de bemonsterde lucht worden bepaald. Met deze methode wordt een gemiddelde concentratie over de 24-uurs meetperiode bepaald en geeft daardoor geen inzicht in het verloop van de $\mathrm{NH}_{3}$ concentraties tijdens de metingen.
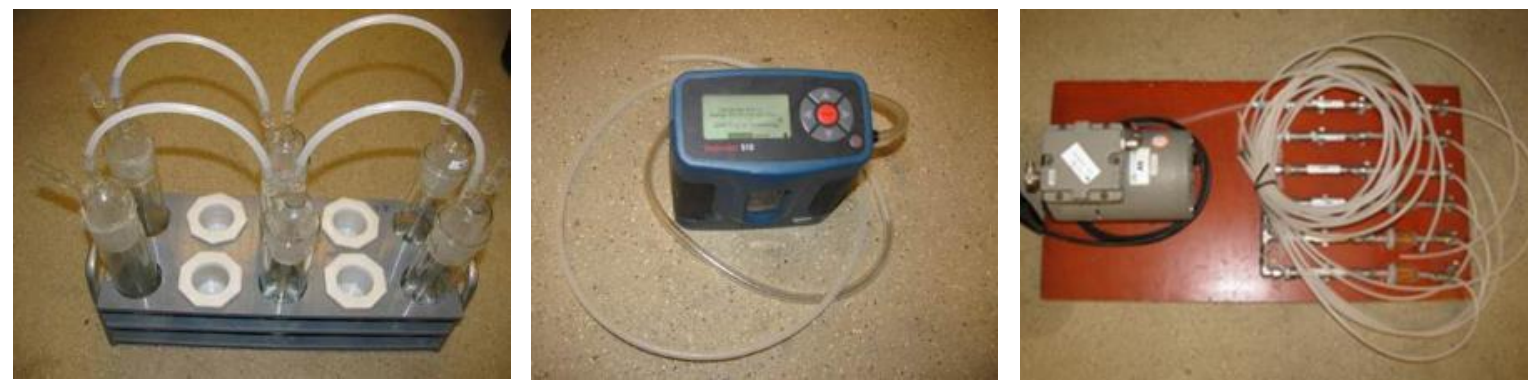

Figuur 1 Meetopstelling nat-chemische methode voor ammoniakemissiemetingen. Links: impingers. Midden: Flowmeter. Rechts: pomp.

\section{Optische metingen (PM10)}

De fijnstofconcentratie (PM10) werd met een lichtverstrooiingstechniek (DustTrak ${ }^{\mathrm{TM}}$ Aerosol Monitor, model 8520, TSI Incorporated, Shoreview, VS) bepaald (figuur 2). De PM10 concentratie werd elke seconde gemeten, minuutgemiddelden werden gelogd in het geheugen van het apparaat en na de metingen gedownload met behulp van de bijbehorende software. 


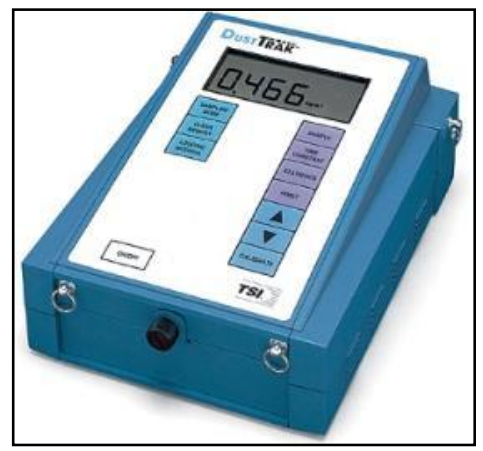

Figuur 2. $\quad$ DustTrak voor continue/optische meting van PM10.

\section{Gravimetrische meetmethode fijn stof (PM10)}

De gravimetrische meetmethode (figuur 3) is er op gebaseerd om het verschil in gewicht van het filter voor en na de meting te bepalen om zodoende de hoeveelheid ingevangen stof vast te stellen. Omdat het bij deze meetmethode slechts om kleine gewichtsverschillen gaat is de meetmethode om het stof te verzamelen aan strikte randvoorwaarde verbonden. De apparatuur voor gravimetrische meting van PM10 is gebaseerd op de standaard referentie monsternamekoppen voor bepaling van PM10concentraties in de buitenlucht (NEN-EN 12341, 1998). Het verschil tussen de gebruikte apparatuur en de standaard apparatuur voor de buitenlucht is dat de impactor voorafscheider is vervangen door een cycloon voorafscheider. Dit vanwege het gevaar van overbelading van de impactieplaat (Zhao e.a., 2009). In Hofschreuder et al. (2008) worden correctielijnen vermeld voor omrekening van de concentraties gemeten met cycloon monsternamekoppen naar impactor monsternamekoppen. De volgende correcties zijn uitgevoerd:

$$
\begin{aligned}
\text { PM10: } & <0,2226 \mathrm{mg} / \mathrm{m}^{3}: Y=1,0877 X \\
& >0,2226 \mathrm{mg} / \mathrm{m}^{3}: Y=0,8304 X+0,057492
\end{aligned}
$$

Voor de bepaling van de concentraties PM10 in de ingaande (achtergrond) en uitgaande stallucht werd lucht door inlaat, cycloon en filter gezogen met monsternamepompen van het type Charlie HV (roterend, $6 \mathrm{~m}^{3} / \mathrm{uur}$, Ravebo Supply BV, Brielle; zie foto hieronder). De pompen werden geprogrammeerd op een flow van $1,0 \mathrm{~m}^{3}$ /uur en op een start- en eindtijd van de monsternameperiode.

PM10 werd verzameld op glasvezelfilters met een diameter van 47 mm (type MN GF-3, MachereyNagel GmbH \& Co., Düren, Duitsland), nadat de grotere stofdeeltjes waren afgescheiden met behulp van een PM10 of PM2,5 cycloon (URG corp., Chapel Hill, VS). De filters werden voor en na de stofmonstername gewogen onder standaard condities: temperatuur $20^{\circ} \mathrm{C} \pm 1{ }^{\circ} \mathrm{C}$ en $50 \% \pm 5 \%$ relatieve luchtvochtigheid (NEN-EN 14907, 2005). De hoeveelheid verzameld stof werd bepaald door het verschil in gewicht te bepalen van het filter voor en na de monstername.

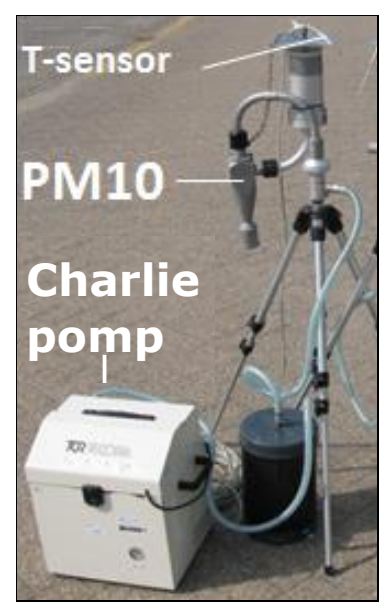

Figuur 3 Gravimetrische methode voor het meten van PM10-concentraties.. 


\section{Longmethode (geur, $\mathrm{CH}_{4}, \mathrm{~N}_{2} \mathrm{O}_{1} \mathrm{CO}_{2}$ )}

In deze methode (Ogink en Mol, 2002) wordt eerst een 40 liter Nalophan monsterzak in een gesloten vat geplaatst. Door lucht uit het vat met behulp van een pomp (Thomas Industries Inc., model 607CD32, Wabasha, Minnesota, VS) via een teflon slang te zuigen, ontstaat in het vat onderdruk en wordt de te bemonsteren lucht aangezogen in de zak.

Bij de bepaling van de geurconcentratie werd gedurende twee uur (tussen 10:00 en 12:00 uur) stallucht aangezogen met een flow van ca. $0,4 \mathrm{l} / \mathrm{min}$ (figuur 4). Voordat de lucht in een geurvrije zak werd verzameld werd deze door een stoffilter geleid (type \#1130, diameter: 50 mm, 1-2 $\mu \mathrm{m}$, Savillex ${ }^{\circledR}$ Corp., Minnetonka, VS). Het monster werd direct na bemonstering naar een geurlaboratorium vervoerd om binnen 30 uur te worden geanalyseerd. De geuranalyses werden uitgevoerd volgens de Europese norm EN 13725 (CEN, 2003). Het geurlaboratorium is onder nummer L400 geaccrediteerd door de Raad voor Accreditatie te Utrecht voor het uitvoeren van geuranalyses.

Bij de bepaling van de concentratie broeikasgassen $\left(\mathrm{CH}_{4}, \mathrm{~N}_{2} \mathrm{O}\right.$ en $\left.\mathrm{CO}_{2}\right)$ werd de monsterzak gedurende 24 uur continu gevuld met een vaste luchtstroom van $0,02 \mathrm{l} / \mathrm{min}$ (figuur 4 ). Het gehalte aan broeikasgassen in het monster werd bepaald met een gaschromatograaf (Interscience/Carbo Erba

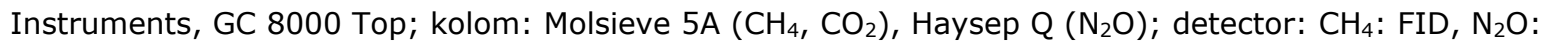
$\mathrm{ECD}, \mathrm{CO}_{2}$ : $\mathrm{HWD}$ ).

Met deze methode wordt een gemiddelde concentratie over de meetperiode ( 2 uur voor geur, 24 uur voor $\mathrm{CH}_{4}, \mathrm{~N}_{2} \mathrm{O}$ en $\mathrm{CO}_{2}$ ) bepaald en geeft daardoor geen inzicht in het verloop van de geur-, $\mathrm{CH}_{4}^{-}, \mathrm{N}_{2} \mathrm{O}-$ en $\mathrm{CO}_{2}$-concentraties tijdens de metingen.

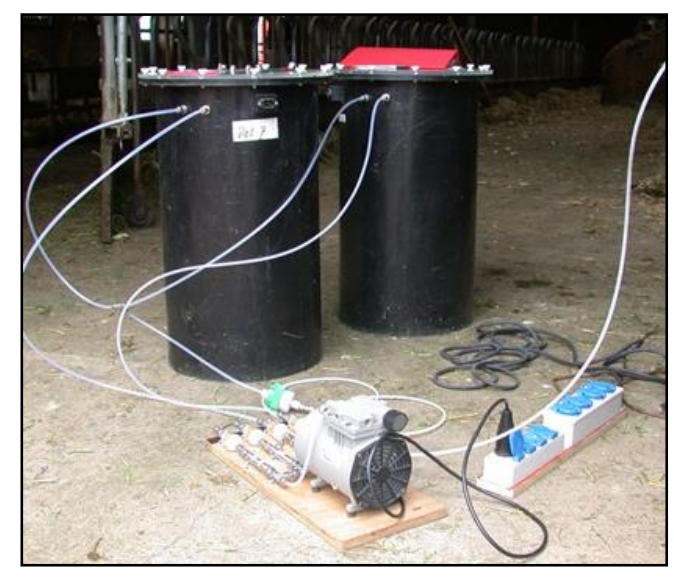

Figuur 4 Longmethode voor het meten van de geur-, CH4-, N2O- en CO2-concentraties.

\section{Foto-akoestische monitor $\left(\mathrm{CO}_{2}\right)$}

Deze meetmethode (figuur 5 ) is gebaseerd op het effect van infrarood licht op gassen. Als een gas wordt blootgesteld aan infrarood licht met een golflengte die dat gas absorbeert zal een deel van het licht worden geabsorbeerd. Als gevolg hiervan krijgt een aantal moleculen een hoger energieniveau wat leidt tot een stijging van temperatuur en druk. Valt het infrarood licht weg dan zullen de moleculen weer terugvallen naar hun oorspronkelijke energieniveau, temperatuur en druk zullen weer dalen. Wanneer een gas pulserend wordt belicht ontstaat een steeds wisselend druk die resulteert in een geluidsgolf die met behulp van microfoons kan worden gedetecteerd. De concentratie van het gas in een monster wordt dan door de sterkte van het signaal bepaald. 


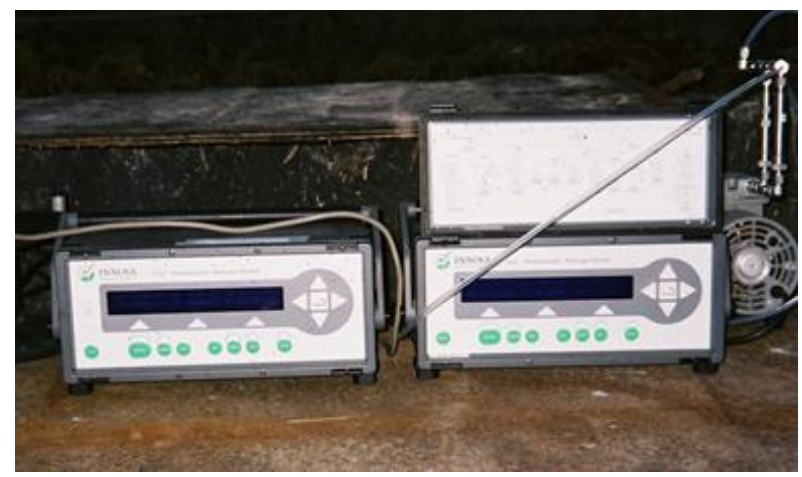

Figuur 5 Meetopstelling voor het meten van de $\mathrm{CO}_{2}$-concentraties met een foto-akoestische monitor.

\section{Temperatuur en relatieve luchtvochtigheid}

Temperatuur $\left({ }^{\circ} \mathrm{C}\right)$ en relatieve luchtvochtigheid $(\%)$ werden continu gemeten met behulp van temperatuur- en vochtsensoren (Rotronic; ROTRONIC Instrument Corp., Huntington, VS; figuur 6), met een nauwkeurigheid van respectievelijk $\pm 1,0^{\circ} \mathrm{C}$ en $\pm 2 \%$. De data werden in een datalogsysteem (Campbell Scientific Inc., Logan, VS) opgeslagen.

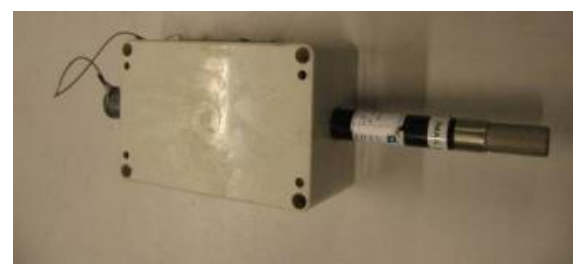

Figuur 6 Meetapparatuur voor het meten van de temperatuur en relatieve luchtvochtigheid

\section{Strooiselmonsters en -dikte}

Gedurende alle meetperioden zijn zowel in de gangpadden als bij de mestbanden (onder de roosters) op 10-15 punten strooiselmonsters genomen (waarbij de gehele laag wordt bemonsterd) en de strooiseldikte gemeten. De strooiselmonsters in de gangpadden en bij de mestbanden werden verzameld in ieder 1 zak ( 2 mengmonsters in totaal) en geanalyseerd op totaal- $\mathrm{N}$, ammonium- $\mathrm{N}$, drogestof en $\mathrm{pH}$. De laagdikte van het strooisel werd gemeten met behulp van een duimstok.

\subsubsection{Productiegegevens}

Gedurende de meetperioden werden de volgende gegevens geregistreerd of berekend:

- Aantal geplaatste dieren

- Aantal aanwezig dieren

- Leeftijd dieren [weken]

- Gemiddeld gewicht dieren [kg]

- Gemiddeld voergebruik per dier [kg]

- Gemiddeld watergebruik per dier [I]

- Aantal eieren en gemiddeld eigewicht [g]

- Uitval [\%], berekend als (1 - [\# hennen aanwezig] / [\# hennen opgezet] )*100 


\subsection{Rekenmethoden}

\subsubsection{Ventilatiedebiet}

Het ventilatiedebiet ( $\mathrm{V} ; \mathrm{m}^{3} /$ uur per dier) werd met behulp van de $\mathrm{CO}_{2}$-massabalansmethode bepaald. De $\mathrm{CO}_{2}$-massabalansmethode maakt gebruik van de gemeten $\mathrm{CO}_{2}$-concentraties van de uit- en ingaande stallucht (respectievelijk $\left[\mathrm{CO}_{2}\right]_{\text {stal }}$ en $\left[\mathrm{CO}_{2}\right]_{\text {buiten }} ; \mathrm{ppm}$ ) en de $\mathrm{CO}_{2}$-productie van de dieren $\left(\mathrm{m}^{3}\right.$ $\mathrm{CO}_{2}$ /dag per dier) in de stal. De $\mathrm{CO}_{2}$-productie van de dieren wordt berekend aan de hand van de CIGR rekenregels voor leghennen (CIGR, 2002; Pedersen e.a., 2008), op basis van het gemiddelde gewicht van de hennen $(\mathrm{m} ; \mathrm{kg})$ en de eiproductie $\left(\mathrm{Y}_{2} ; \mathrm{kg}\right.$ ei/hen per dag, berekend op basis van het aantal hennen, het aantal eieren per dag en het gemiddelde eigewicht):

$$
\mathrm{CO}_{2}-\text { productie }=0,18 *\left(6,3 * m^{0,75}+25 * Y_{2}\right)
$$

Het ventilatiedebiet $V\left(\mathrm{~m}^{3} /\right.$ uur per dier) wordt dan bepaald op basis van:

$$
V=\frac{\mathrm{CO}_{2}-\text { productie }}{\left[\mathrm{CO}_{2}\right]_{\text {stal }}-\left[\mathrm{CO}_{2}\right]_{\text {buiten }}} \cdot \frac{10^{6}}{24}
$$

\subsubsection{Emissies}

Per meetserie $(i=1,2, \ldots, 13)$ werden de emissies $\left(E_{i} ; g / j a a r\right.$ per geplaatst dier) van ammoniak, PM10, en broeikasgassen voor zowel de 'controle-dag' als voor de 'case-dag' bepaald op basis van het gemiddeld ventilatiedebiet over de gehele meetperiode (24-uursgemiddelde; $V_{i}\left[\mathrm{~m}^{3} /\right.$ uur per dier aanwezig]) en de gemiddelde concentratie (24-uursgemiddelde) in de uitgaande lucht (C_uit $\left[\mathrm{g} / \mathrm{m}^{3}\right]$ ) en in de ingaande (achtergrond)lucht $\left(C_{-} \mathrm{in}_{\mathrm{i}}\left[\mathrm{g} / \mathrm{m}^{3}\right]\right.$ ). De emissies op jaarbasis werden uitgedrukt per geplaatst dier en gecorrigeerd voor een leegstandsperiode voor leghennen van 4\% (Ogink et al., 2014):

$$
\begin{aligned}
& E_{i}(\text { controle })=V_{i} *\left(C_{-} \text {uit }_{i}-C_{-} \text {in }_{i}\right) *\left(\frac{\text { dieren_aanwezig }_{i}}{\text { dieren_geplaatst }_{i}}\right) * 24 * 365 * 0,96 \\
& E_{i}(\text { case })=V_{i} *\left(C_{-} \text {uit }_{i}-C_{-} \text {in }_{i}\right) *\left(\frac{\text { dieren_aanwezig }_{i}}{\text { dieren_geplaatst }_{i}}\right) * 24 * 365 * 0,96
\end{aligned}
$$

Per meetserie $(i=1,2, \ldots, 13)$ werden de emissies ( $E i ; O U_{E} / s$ per geplaatst dier) van geur voor zowel de 'controle-dag' als voor de 'case-dag' bepaald op basis van het gemiddeld ventilatiedebiet over de gehele meetperiode (24-uursgemiddelde; $V_{i}\left[\mathrm{~m}^{3} / \mathrm{uur}\right.$ per dier aanwezig]) en de gemiddelde concentratie (2-uursgemiddelde) in de uitgaande lucht (C_uit $\left.\mathrm{COU}_{\mathrm{E}} / \mathrm{m}^{3}\right]$ ). De emissies op jaarbasis werden uitgedrukt per geplaatst dier en gecorrigeerd voor een leegstandsperiode voor leghennen van 4\% (Ogink et al., 2013):

$$
\begin{aligned}
& E_{i}(\text { controle })=V_{i} * C_{-} \text {uit }_{i} *\left(\frac{\text { dieren_aanwezig }_{i}}{\text { dieren_eplaatst }_{i}}\right) * \frac{1}{3600} * 0,96 \\
& E_{i}(\text { case })=V_{i} * C_{-} \text {uit }_{i} *\left(\frac{\text { dieren_aanwezig }_{i}}{\text { dieren_geplaatst }_{i}}\right) * \frac{1}{3600} * 0,96
\end{aligned}
$$




\subsubsection{Emissiereductie}

Per meetserie $(i=1,2, \ldots, 13)$ werd de emissiereductie $\left(E R_{i} ; \%\right)$ van het verwijdering van de strooisel in de stal bepaald als het relatieve verschil tussen de emissies:

$$
E R_{i}=\left(1-\frac{E_{i}(\text { case })}{E_{i}(\text { controle })}\right) \times 100
$$

Vervolgens werd de gemiddelde emissiereductie ( $E R ; \%)$ bepaald als het gemiddelde van de emissiereducties van de individuele metingen:

$$
\mathrm{ER}=\overline{\mathrm{ER}_{\mathrm{i}}}
$$

\subsubsection{Statistische analyse}

De data werd gecontroleerd op de aanwezigheid van uitbijters door middel van de boxplot-methode met driemaal de IKA-waarde (interkwartiel-afstand) als maat voor uitbijter. De volgende procedure werd toegepast:

1. Per meetserie $(i=1,2, . ., 13)$ is gekeken naar de verhouding tussen het verschil in waarde en de gemiddelde waarde van de metingen bij de controle- en de case-dagen:

$$
\text { verhouding }_{i}=\frac{\mid E_{i}(\text { controle })-E_{i}(\text { case }) \mid}{\left(E_{i}(\text { controle })+E_{i}(\text { case })\right) / 2}
$$

2. Met deze verhouding-getallen is een database gemaakt en de volgende parameters bepaald:

a. het eerste kwartiel (Q1): ten minste $1 / 4$ van de data is niet groter dan Q1, en ten minste 3/4 van de data is niet kleiner dan Q1

b. het derde kwartiel (Q3): ten minste 3/4 van de data is niet groter dan Q3, en ten minste 1/4 van de data is niet kleiner dan Q3

c. het interkwartiel-afstand (IKA): IKA = Q3-Q1

d. ondergrens voor uitbijter: Uit_onder $=\mathrm{Q} 1-3 * I K A$

e. bovengrens voor uitbijter: Uit_boven $=\mathrm{Q} 3+3 * I K A$

3. Waarden in een meetserie worden als uitbijter beschouwd wanneer:

a. verhouding $i$ Uit_onder of

b. verhouding ${ }_{i}>$ Uit_boven

De statistische dubbelzijdig gepaarde t-toets werd gebruikt om te toetsen of het verschil in emissie tussen de controle (strooisel-laag zoals aangetroffen in de stal vóór verwijdering) en de case (dunnere strooisel-laag) significant afweek van nul. Alle analyses werden gedaan met behulp van de GenStat software. De significantie van de verschillen werd als volgt bepaald uit de geschatte P-waarde van de nulhypothese:

- $P<0,05$ : significante verschillen

- $0,05<P<0,10$ : aanwijzing voor significantie / zwak significantie

- $P>0,10$ : verschillen zijn niet significant 


\section{Resultaten en discussie}

\subsection{Meetomstandigheden}

In Tabel 6A t/m Tabel 6E worden de omstandigheden weergegeven waaronder de metingen zijn verricht bij alle vijf locaties. De metingen zijn over een periode van 287 dagen in het kalenderjaar verdeeld (figuur 7). De dieren waren gemiddeld 50 weken (tussen 25 en 88 weken) in de productieronde tijdens de metingen. De (daggemiddelde) $\mathrm{CO}_{2}$-concentratie in de stal lag gedurende alle meetdagen onder de 2500 ppm (uitgezonderd meetdag 5 bij locatie 4 waar een gemiddelde CO2concentratie van 2501 ppm werd gemeten). Het uitvalspercentage was gemiddeld 5,4\% tijdens de metingen en was, behalve bij meetserie 3 op locaties 4 en 5, altijd lager dan 10\%. De water-voer verhouding varieerde tussen 1,6 en 1,9 tijdens de metingen, met een gemiddelde van 1,8 over alle metingen. De dikte van de strooisel-laag was gemiddeld $6,0 \pm 1,5 \mathrm{~cm}$ [en varieerde tussen 3,5 en 9,3 $\mathrm{cm}$ ] vóór het verwijdering van de strooisel (controle). De dikte van de strooisel-laag was gemiddeld $2,0 \pm 1,0 \mathrm{~cm}$ [en varieerde tussen 0,6 en $3,8 \mathrm{~cm}$ ] na het verwijdering van de strooisel.

In figuur 8 worden de gemeten buitentemperatuur en relatieve luchtvochtigheid vergeleken met de gemiddelde waarden gemeten over de jaren 2004-2013 bij het KNMI-weerstation De Bilt. De gemiddelde buitentemperatuur op de dagen waarop is gemeten met een dikke strooisel-laag $\left(13,8{ }^{\circ} \mathrm{C}\right)$ is $3,3{ }^{\circ} \mathrm{C}$ hoger en de relatieve luchtvochtigheid $(80,2 \%)$ vergelijkbaar met het langjarige gemiddelde in Nederland $\left(10,5^{\circ} \mathrm{C}\right.$ en $\left.81,1 \%\right)$. De gemiddelde buitentemperatuur op de dagen waarop is gemeten met een dunne strooisel-laag $\left(14,1{ }^{\circ} \mathrm{C}\right)$ is $3,5^{\circ} \mathrm{C}$ hoger en de relatieve luchtvochtigheid $(78,6 \%) 2,5 \%$ lager dan het langjarige gemiddelde in Nederland.
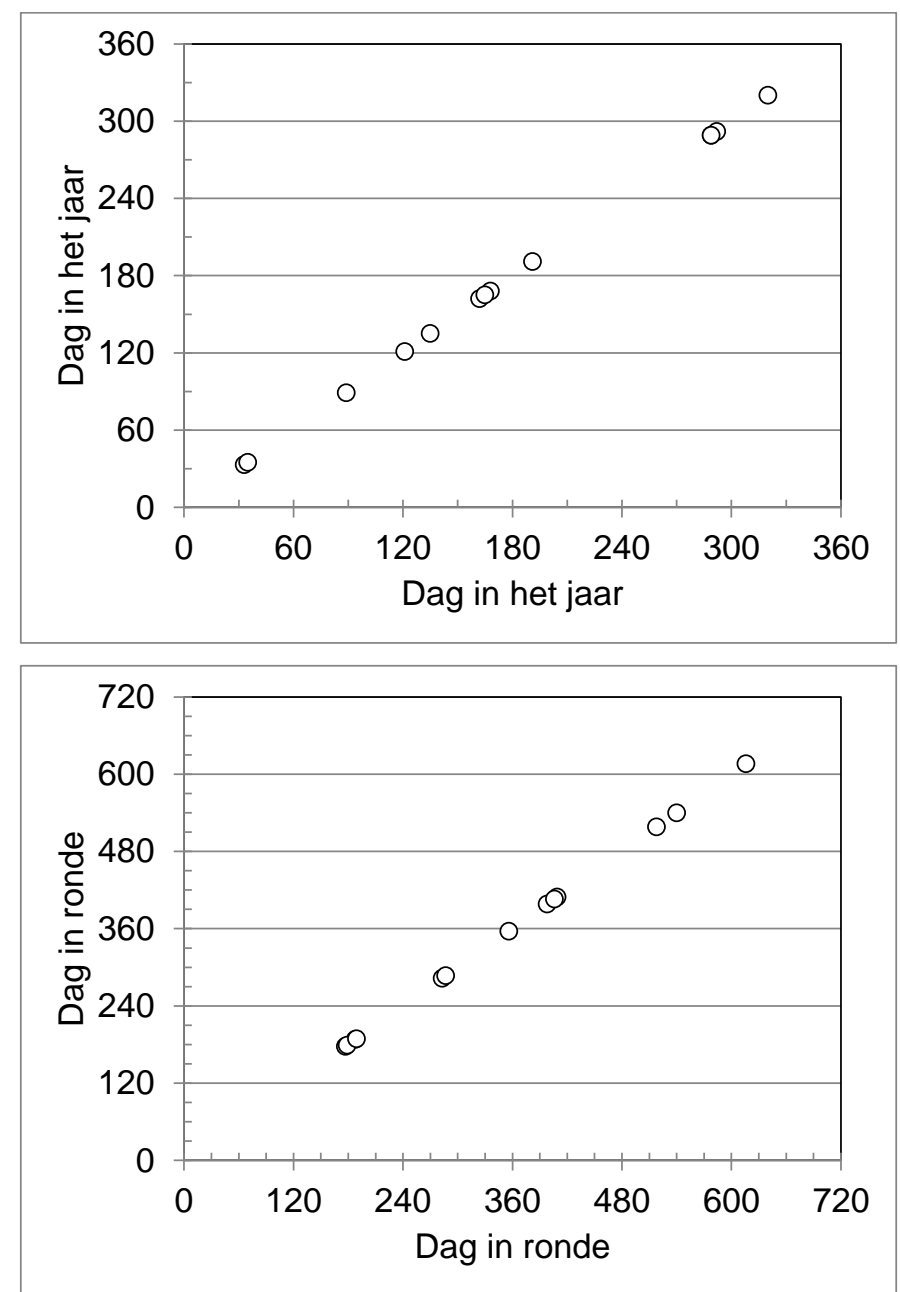

Figuur $7 \quad$ Verdeling van de metingen in het jaar (boven) en in de productieronde (onder). 

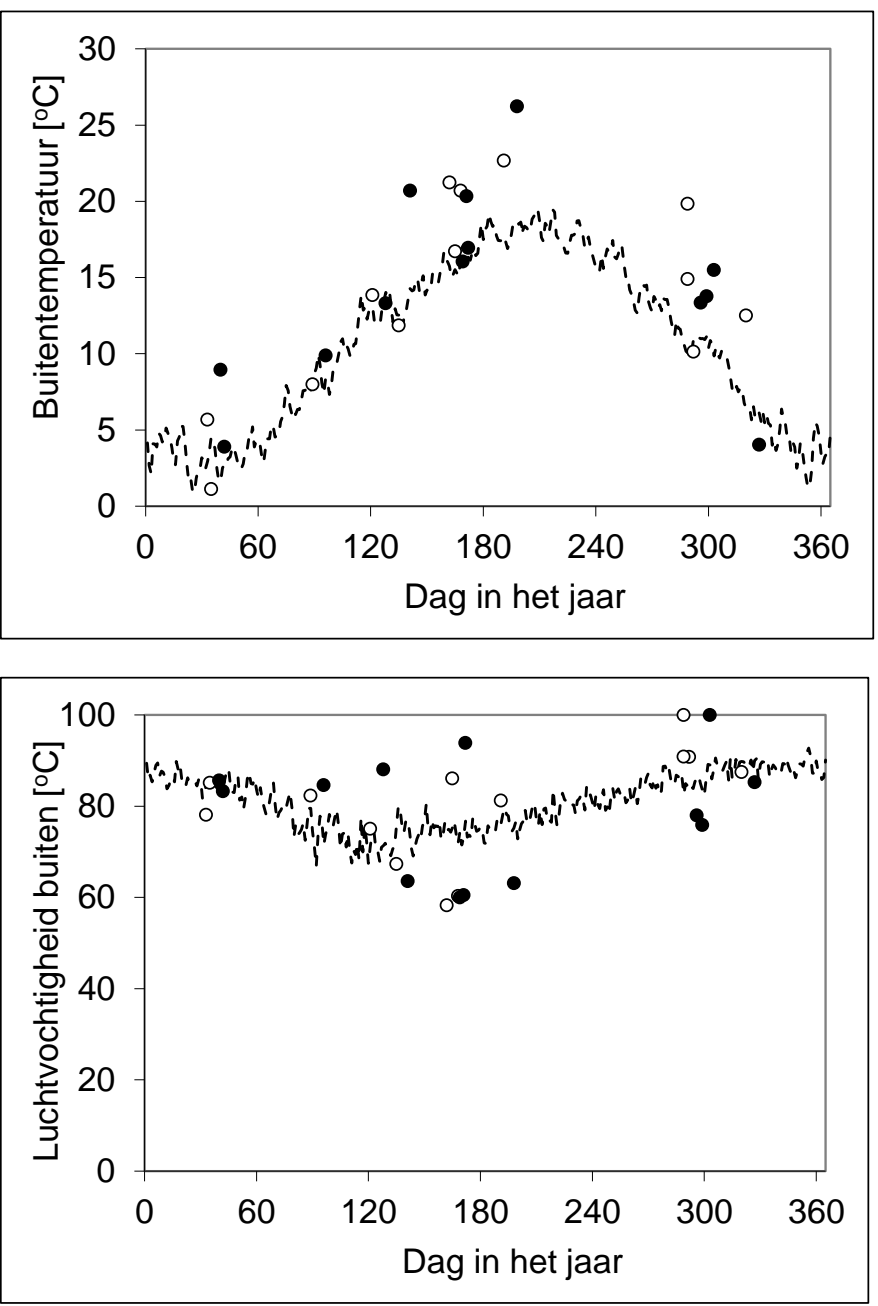

Figur 8 Buitentemperatuur (boven) en relatieve luchtvochtigheid (onder) vergeleken met de gemiddelde waarden gemeten over de jaren 2004-2013 bij het KNMI-weerstation De Bilt (www.knmi.nl; als stippellijn weergegeven).

\subsection{Strooiselmonsters}

In tabel $6 \mathrm{~A} \mathrm{t} / \mathrm{m}$ tabel $6 \mathrm{E}$ worden de resultaten van de strooiselanalyses weergegeven. De resultaten van de strooiselmonsters genomen bij metingen met een dunnere strooisel-laag (case) waren voor zowel $\mathrm{pH}$, ds, Totaal- $\mathrm{N}$ als Ammonium- $\mathrm{N}$ niet significant verschillend $(\mathrm{P}>0,10)$ t.o.v. de waarden van de metingen met een dikkere strooisel-laag (controle). De $\mathrm{pH}$ van het strooisel was gemiddeld 8,2 \pm 0,5 vóór het verwijderen van het strooisel en $8,1 \pm 0,6$ na het verwijderen van het strooisel. Het drogestofgehalte van het strooisel was gemiddeld $755 \pm 68 \mathrm{~g} / \mathrm{kg}$ vóór het verwijderen van het strooisel en $741 \pm 74 \mathrm{~g} / \mathrm{kg}$ na het verwijderen van het strooisel. Het totaal stikstofgehalte van het strooisel was gemiddeld 23,5 $\pm 3,2 \mathrm{~g} / \mathrm{kg}$ vóór het verwijderen van het strooisel en 23,6 $\pm 2,6 \mathrm{~g} / \mathrm{kg}$ na het verwijderen van het strooisel. Het ammoniumgehalte van het strooisel was gemiddeld 2,7 $\pm 0,8$ $\mathrm{g} / \mathrm{kg}$ vóór het verwijderen van het strooisel en $2,5 \pm 1,0 \mathrm{~g} / \mathrm{kg}$ na het verwijderen van het strooisel. 


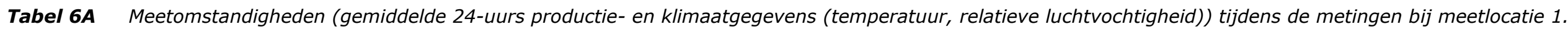

\begin{tabular}{|c|c|c|c|c|}
\hline \multirow{2}{*}{ Resultaten } & \multicolumn{2}{|c|}{ Meting 1} & \multicolumn{2}{|c|}{ Meting 2} \\
\hline & Dikke laag & Dunne laag & Dikke laag & Dunne laag \\
\hline Datum meetdag & $1-5-2014$ & $8-5-2014$ & $16-10-2014$ & $30-10-2014$ \\
\hline Dag in het jaar & 121 & 128 & 289 & 303 \\
\hline Aantal geplaatste dieren & 15800 & 15800 & 15800 & 15800 \\
\hline Aantal aanwezige dieren op meetdag & 15477 & 15450 & 14327 & 14302 \\
\hline Eierenproductie [kg/dier/dag] & 0,06 & 0,06 & 0,05 & 0,05 \\
\hline Uitval [\%] & 2,0 & 2,2 & 9,3 & 9,5 \\
\hline \multicolumn{5}{|l|}{ Strooiseleigenschappen } \\
\hline Strooiseldikte gang $[\mathrm{cm}]$ & 4,0 & 0,7 & 5,5 & 0,4 \\
\hline Strooiseldikte rooster $[\mathrm{cm}]$ & 5,7 & 0,5 & 7,7 & 0,8 \\
\hline Totaal-N $[\mathrm{g} / \mathrm{kg}]$ & 24,2 & 25,1 & 24,2 & 23,0 \\
\hline Drogestof $[\mathrm{g} / \mathrm{kg}]$ & 783,4 & 750,5 & 790,7 & 752,3 \\
\hline $\mathrm{pH}$ & 8,6 & 8,4 & 8,5 & 8,6 \\
\hline Voergebruik [kg per dier per week] & 0,9 & 0,9 & 0,8 & 0,8 \\
\hline Watergebruik [I per dier per week] & 1,6 & 1,6 & 1,4 & 1,4 \\
\hline Water-voer verhouding & 1,8 & 1,8 & 1,8 & 1,8 \\
\hline T stal $\left[{ }^{\circ} \mathrm{C}\right]$ & 22,3 & 22,7 & 23,6 & 22,0 \\
\hline RV stal $[\%]$ & 61,6 & 75,4 & 68,5 & 69,7 \\
\hline T buiten $\left[{ }^{\circ} \mathrm{C}\right]$ & 13,8 & 13,3 & 14,9 & 15,5 \\
\hline RV buiten [\%] & 75,0 & 88,1 & 100,0 & 100,0 \\
\hline $\mathrm{CO}_{2}$-stalconcentratie $[\mathrm{ppm}]$ & 1178 & 1403 & 1190 & 1160 \\
\hline Debiet [ $\left.\mathrm{m}^{3} / \mathrm{uur} / \mathrm{dier}\right]$ & 3,2 & 2,5 & 3,1 & 3,4 \\
\hline
\end{tabular}




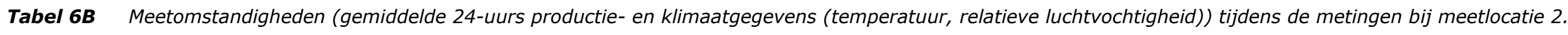

\begin{tabular}{|c|c|c|c|c|c|c|}
\hline \multirow{2}{*}{ Resultaten } & \multicolumn{2}{|c|}{ Meting 1} & \multicolumn{2}{|c|}{ Meting 2} & \multicolumn{2}{|c|}{ Meting 3} \\
\hline & Dikke laag & Dunne laag & Dikke laag & Dunne laag & Dikke laag & Dunne laag \\
\hline Datum meetdag & $15-5-2014$ & $21-5-2014$ & $19-10-2015$ & $26-10-2015$ & $10-6-2016$ & $17-6-2016$ \\
\hline Dag in het jaar & 135 & 141 & 292 & 299 & 162 & 169 \\
\hline Aantal geplaatste dieren & 17706 & 17706 & 18000 & 18000 & 18000 & 18000 \\
\hline Aantal aanwezige dieren op meetdag & 17336 & 17316 & 17675 & 17672 & 17059 & 17059 \\
\hline Eierenproductie [kg/dier/dag] & 0,06 & 0,06 & 0,06 & 0,06 & 0,06 & 0,06 \\
\hline Uitval [\%] & 2,1 & 2,2 & 1,8 & 1,8 & 5,2 & 5,2 \\
\hline \multicolumn{7}{|l|}{ Strooiseleigenschappen } \\
\hline Strooiseldikte gang $[\mathrm{cm}]$ & 6,4 & 2,3 & 3,5 & 1,2 & 4,6 & 2,1 \\
\hline Strooiseldikte rooster $[\mathrm{cm}]$ & 0,9 & 2,0 & 1,0 & 1,1 & 2,0 & 2,0 \\
\hline Totaal- $\mathrm{N}[\mathrm{g} / \mathrm{kg}]$ & 24,4 & 25,0 & 17,6 & 19,1 & 20,9 & 25,2 \\
\hline Drogestof $[\mathrm{g} / \mathrm{kg}]$ & 777,5 & 786,8 & 592,2 & 563,1 & 666,9 & 647,9 \\
\hline $\mathrm{pH}$ & 8,8 & 8,7 & 8,3 & 7,9 & 7,3 & 6,9 \\
\hline Voergebruik [kg per dier per week] & 0,9 & 0,9 & 0,8 & 0,8 & 0,8 & 0,8 \\
\hline Watergebruik [I per dier per week] & 1,5 & 1,5 & 1,5 & 1,4 & 1,6 & 1,6 \\
\hline Water-voer verhouding & 1,8 & 1,8 & 1,9 & 1,8 & 1,9 & 1,9 \\
\hline T stal $\left[{ }^{\circ} \mathrm{C}\right]$ & 20,1 & 24,0 & 21,1 & 21,4 & 22,3 & 18,8 \\
\hline RV stal [\%] & 59,2 & 58,8 & 74,6 & 71,3 & 59,7 & 58,9 \\
\hline $\mathrm{T}$ buiten $\left[{ }^{\circ} \mathrm{C}\right]$ & 11,8 & 20,7 & 10,1 & 13,8 & 21,2 & 16,0 \\
\hline RV buiten [\%] & 67,3 & 63,6 & 90,8 & 75,9 & 58,3 & 60,0 \\
\hline $\mathrm{CO}_{2}$-stalconcentratie $[\mathrm{ppm}]$ & 2000 & 800 & 1421 & 1373 & 819 & 1173 \\
\hline Debiet $\left[\mathrm{m}^{3} / \mathrm{uur} /\right.$ dier] & 1,6 & 7,1 & 2,1 & 2,2 & 4,7 & 2,9 \\
\hline
\end{tabular}




\begin{tabular}{|c|c|c|c|c|}
\hline \multirow{2}{*}{ Resultaten } & \multicolumn{2}{|c|}{ Meting 1} & \multicolumn{2}{|c|}{ Meting 2} \\
\hline & Dikke laag & Dunne laag & Dikke laag & Dunne laag \\
\hline Datum meetdag & $17-6-2014$ & $20-6-2014$ & $2-2-2015$ & $9-2-2015$ \\
\hline Dag in het jaar & 168 & 171 & 33 & 40 \\
\hline Aantal geplaatste dieren & 22922 & 22922 & 22922 & 22922 \\
\hline Aantal aanwezige dieren op meetdag & 22520 & 22518 & 21851 & 21829 \\
\hline Eierenproductie [kg/dier/dag] & 0,06 & 0,06 & 0,06 & 0,06 \\
\hline Uitval [\%] & 1,8 & 1,8 & 4,7 & 4,8 \\
\hline \multicolumn{5}{|l|}{ Strooiseleigenschappen } \\
\hline Strooiseldikte gang $[\mathrm{cm}]$ & 5,7 & 1,8 & 5,2 & 1,6 \\
\hline Strooiseldikte rooster $[\mathrm{cm}]$ & 4,6 & 1,7 & 4,7 & 2,6 \\
\hline Totaal-N $[\mathrm{g} / \mathrm{kg}]$ & 26,3 & 26,8 & 22,3 & 23,4 \\
\hline Drogestof $[\mathrm{g} / \mathrm{kg}]$ & 830,4 & 833,4 & 757,8 & 761,6 \\
\hline $\mathrm{pH}$ & 8,5 & 8,4 & 8,0 & 8,0 \\
\hline Voergebruik [kg per dier per week] & 0,8 & 0,8 & 0,9 & 0,9 \\
\hline Watergebruik [I per dier per week] & 1,6 & 1,6 & 1,6 & 1,6 \\
\hline Water-voer verhouding & 1,9 & 1,9 & 1,9 & 1,9 \\
\hline T stal $\left[{ }^{\circ} \mathrm{C}\right]$ & 24,7 & 24,6 & 21,2 & 21,1 \\
\hline RV stal $[\%]$ & 58,9 & 59,1 & 64,4 & 66,0 \\
\hline T buiten $\left[{ }^{\circ} \mathrm{C}\right]$ & 20,7 & 20,3 & 5,7 & 8,9 \\
\hline RV buiten [\%] & 60,3 & 60,5 & 78,1 & 85,6 \\
\hline $\mathrm{CO}_{2}$-stalconcentratie $[\mathrm{ppm}]$ & 1115 & 1070 & 2342 & 1943 \\
\hline Debiet [ $\left.\mathrm{m}^{3} / \mathrm{uur} / \mathrm{dier}\right]$ & 3,3 & 3,8 & 1,2 & 1,6 \\
\hline
\end{tabular}




\begin{tabular}{|c|c|c|c|c|c|c|}
\hline \multirow{2}{*}{ Resultaten } & \multicolumn{2}{|c|}{ Meting 1} & \multicolumn{2}{|c|}{ Meting 2} & \multicolumn{2}{|c|}{ Meting 3} \\
\hline & Dikke laag & Dunne laag & Dikke laag & Dunne laag & Dikke laag & Dunne laag \\
\hline Datum meetdag & $10-7-2014$ & $17-7-2014$ & $16-10-2014$ & $23-10-2014$ & $4-2-2015$ & $11-2-2015$ \\
\hline Dag in het jaar & 191 & 198 & 289 & 296 & 35 & 42 \\
\hline Aantal geplaatste dieren & 24200 & 24200 & 24200 & 24200 & 24200 & 24200 \\
\hline Aantal aanwezige dieren op meetdag & 23858 & 23835 & 23023 & 23000 & 21700 & 21700 \\
\hline Eierenproductie [kg/dier/dag] & 0,06 & 0,06 & 0,06 & 0,06 & 0,06 & 0,06 \\
\hline Uitval [\%] & 1,4 & 1,5 & 4,9 & 5,0 & 10,3 & 10,3 \\
\hline \multicolumn{7}{|l|}{ Strooiseleigenschappen } \\
\hline Strooiseldikte gang [cm] & 7,5 & 0,5 & 4,1 & 0,3 & 6,7 & 2,3 \\
\hline Strooiseldikte rooster $[\mathrm{cm}]$ & 7,2 & 2,0 & 5,8 & 2,3 & 6,2 & 4,5 \\
\hline Totaal- $\mathrm{N}[\mathrm{g} / \mathrm{kg}]$ & 29,9 & 28,2 & 27,0 & 25,0 & 24,2 & 22,8 \\
\hline Drogestof $[\mathrm{g} / \mathrm{kg}]$ & 814,8 & 809,9 & 827,6 & 810,3 & 773,5 & 772,3 \\
\hline $\mathrm{pH}$ & 8,3 & 8,5 & 8,2 & 8,5 & 8,1 & 8,1 \\
\hline Voergebruik [kg per dier per week] & 0,8 & 0,8 & 0,9 & 0,9 & 0,9 & 0,90 \\
\hline Watergebruik [I per dier per week] & 1,5 & 1,5 & 1,4 & 1,4 & 1,5 & 1,49 \\
\hline Water-voer verhouding & 1,8 & 1,8 & 1,6 & 1,6 & 1,7 & 1,67 \\
\hline T stal $\left[{ }^{\circ} \mathrm{C}\right]$ & 25,6 & 26,7 & 23,2 & 22,9 & 19,8 & 20,2 \\
\hline RV stal [\%] & 71,2 & 60,6 & 69,0 & 60,4 & 59,1 & 58,7 \\
\hline T buiten $\left[{ }^{\circ} \mathrm{C}\right]$ & 22,7 & 26,2 & 19,8 & 13,4 & 1,1 & 3,9 \\
\hline RV buiten [\%] & 81,2 & 63,1 & 90,9 & 78,0 & 85,1 & 83,3 \\
\hline $\mathrm{CO}_{2}$-stalconcentratie $[\mathrm{ppm}]$ & 814 & 812 & 1130 & 1300 & 2501 & 2195 \\
\hline Debiet [m³/uur/dier] & 5,7 & 5,7 & 3,5 & 2,5 & 1,1 & 1,3 \\
\hline
\end{tabular}




\begin{tabular}{|c|c|c|c|c|c|c|}
\hline \multirow{2}{*}{ Resultaten } & \multicolumn{2}{|c|}{ Meting 1} & \multicolumn{2}{|c|}{ Meting 2} & \multicolumn{2}{|c|}{ Meting 3} \\
\hline & Dikke laag & Dunne laag & Dikke laag & Dunne laag & Dikke laag & Dunne laag \\
\hline Datum meetdag & $16-11-2015$ & 23-11-2015 & $29-3-2016$ & $5-4-2016$ & $13-6-2016$ & $20-6-2016$ \\
\hline Dag in het jaar & 320 & 327 & 89 & 96 & 165 & 172 \\
\hline Aantal geplaatste dieren & 9036 & 9036 & 9036 & 9036 & 9036 & 9036 \\
\hline Aantal aanwezige dieren op meetdag & 8392 & 8367 & 8289 & 8283 & 8110 & 8077 \\
\hline Eierenproductie [kg/dier/dag] & 0,04 & 0,05 & 0,06 & 0,06 & 0,05 & 0,05 \\
\hline Uitval [\%] & 7,1 & 7,4 & 8,3 & 8,3 & 10,2 & 10,6 \\
\hline \multicolumn{7}{|l|}{ Strooiseleigenschappen } \\
\hline Strooiseldikte gang $[\mathrm{cm}]$ & 6,3 & 2,7 & 9,1 & 3,1 & 6,4 & 1,8 \\
\hline Strooiseldikte rooster $[\mathrm{cm}]$ & 7,5 & 3,3 & 9,4 & 4,5 & 7,3 & 3,3 \\
\hline Totaal-N [g/kg] & 21,5 & 20,4 & 20,2 & 20,5 & 22,1 & 22,4 \\
\hline Drogestof $[\mathrm{g} / \mathrm{kg}]$ & 744,5 & 704,4 & 694,8 & 697,7 & 767,2 & 737,0 \\
\hline $\mathrm{pH}$ & 8,9 & 8,7 & 7,7 & 7,7 & 7,3 & 7,1 \\
\hline Voergebruik [kg per dier per week] & 0,9 & 0,9 & 0,9 & 0,9 & 0,9 & 0,9 \\
\hline Watergebruik [I per dier per week] & 1,5 & 1,6 & 1,5 & 1,5 & 1,6 & 1,4 \\
\hline Water-voer verhouding & 1,6 & 1,7 & 1,7 & 1,7 & 1,7 & 1,6 \\
\hline T stal $\left[{ }^{\circ} \mathrm{C}\right]$ & 22,2 & 20,3 & 22,3 & 22,4 & 22,7 & 23,1 \\
\hline RV stal [\%] & 75,0 & 74,7 & 68,8 & 68,5 & 79,5 & 81,5 \\
\hline T buiten $\left[{ }^{\circ} \mathrm{C}\right]$ & 12,5 & 4,0 & 8,0 & 9,9 & 16,7 & 16,9 \\
\hline RV buiten [\%] & 87,5 & 85,2 & 82,3 & 84,6 & 86,1 & 93,9 \\
\hline $\mathrm{CO}_{2}$-stalconcentratie $[\mathrm{ppm}]$ & 1566 & 2310 & 2175 & 1955 & 1150 & 1083 \\
\hline Debiet [m³/uur/dier] & 1,8 & 1,1 & 1,2 & 1,4 & 2,8 & 3,1 \\
\hline
\end{tabular}




\subsection{Ventilatiedebieten}

Het ventilatiedebiet was voor alle metingen (met uitzondering van meting 1 bij locatie 2) vergelijkbaar vóór en na verwijdering van de strooisel (tabel 7 en figuur 9). Een statistische analyse (zie hoofdstuk 2.3.4) toonde aan dat meting 1 bij locatie 2 als uitbijter (wat betreft ventilatiedebiet) kan worden beschouwd. Een mogelijk verklaring voor dit grote verschil bij deze meetserie was de veel hogere buitentemperatuur tijdens de metingen met een dunne strooisel-laag ten opzichte van de buitentemperatuur tijdens de metingen met een dikke strooisel-laag. Gemiddeld over alle metingen was het ventilatiedebiet $2,7 \pm 1,4 \mathrm{~m}^{3}$ /uur per dier in de meetperioden met een dikke laag strooisel, en $3,0 \pm 1,7 \mathrm{~m}^{3}$ /uur per dier in de meetperioden met een dunne laag strooisel. Zonder uitbijters (meting 1 bij locatie 2) was het ventilatiedebiet gemiddeld $2,8 \pm 1,4 \mathrm{~m}^{3} /$ uur per dier in de meetperioden met een dikke strooisel-laag, en 2,6 $\pm 1,3 \mathrm{~m}^{3} /$ uur per dier in de meetperioden met een dunne strooisellaag. De meetomstandigheden wat betreft ventilatiedebiet kunnen als vergelijkbaar worden beschouwd.
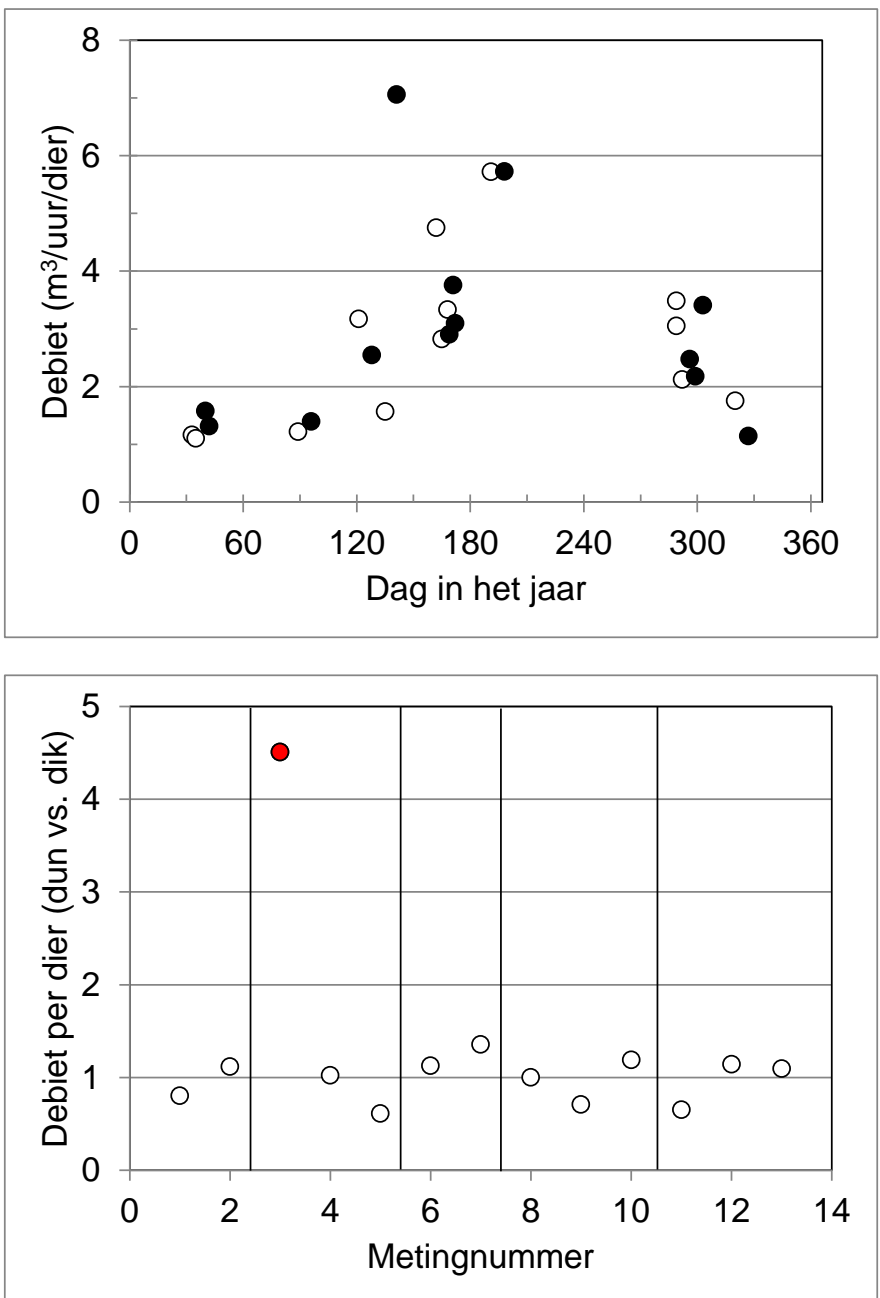

Figuur 9 Boven: Gemiddelde ventilatiedebiet [ $\mathrm{m}^{3} / \mathrm{uur}$ per dier] voor alle metingen. Open symbolen: dikke laag (controle); Gesloten symbolen: dunne laag (case). Onder: Ventilatiedebiet voor de metingen met een dunne strooisel-laag vs. ventilatiedebiet voor de metingen met een dikke strooisel-laag. De verticale lijnen worden gebruikt om onderscheid te maken tussen de metingen op de verschillende meetlocaties. De uitbijters worden in rood weergegeven. 


\subsection{Ammoniak $\left(\mathrm{NH}_{3}\right)$}

In figuur 10 worden de $\mathrm{NH}_{3}$-emissies en de gemeten emissiereducties weergegeven. De meetdata bevatte geen uitbijters. De veel hogere ventilatie bij meting 1 op locatie 2 tijdens de metingen met een dunne strooisel-laag t.o.v. van de metingen bij een dikkere strooisel-laag heeft niet geleid tot extreem hogere $\mathrm{NH}_{3}$-emissies. Gemiddeld over alle metingen (tabel 7 en figuur 10 ) was de $\mathrm{NH}_{3}-$ emissie $188 \pm 65 \mathrm{~g} /$ jaar per geplaatst dier (emissies gecorrigeerd door $4 \%$ leegstand) in de meetperioden met een dikke strooisel-laag, en $147 \pm 65 \mathrm{~g} / \mathrm{jaar}$ per geplaatst dier (emissies gecorrigeerd door $4 \%$ leegstand) in de meetperioden met een dunne strooisel-laag. De gemiddelde emissies over alle metingen (dikke en dunne strooisel-laag) was $174 \pm 69 \mathrm{~g} / \mathrm{jaar}$ per geplaatst dier (emissies gecorrigeerd door 4\% leegstand). Dit is iets hoger dan de emissies (129 $\pm 80 \mathrm{~g} / \mathrm{jaar}$ per geplaatst dier; emissies gecorrigeerd door 4\% leegstand) gerapporteerd in Winkel e.a. (2011) bij metingen aan vier bedrijven met leghennen in volièrehuisvesting, en de emissiefactoren in de Rav voor volièrehuisvesting met mestbanden en mestbeluchting (25-90 g/jaar per geplaatst dier). De gemiddelde emissie in Winkel e.a. (2011) was gebaseerd op 22 metingen verdeeld over het gehele jaar.
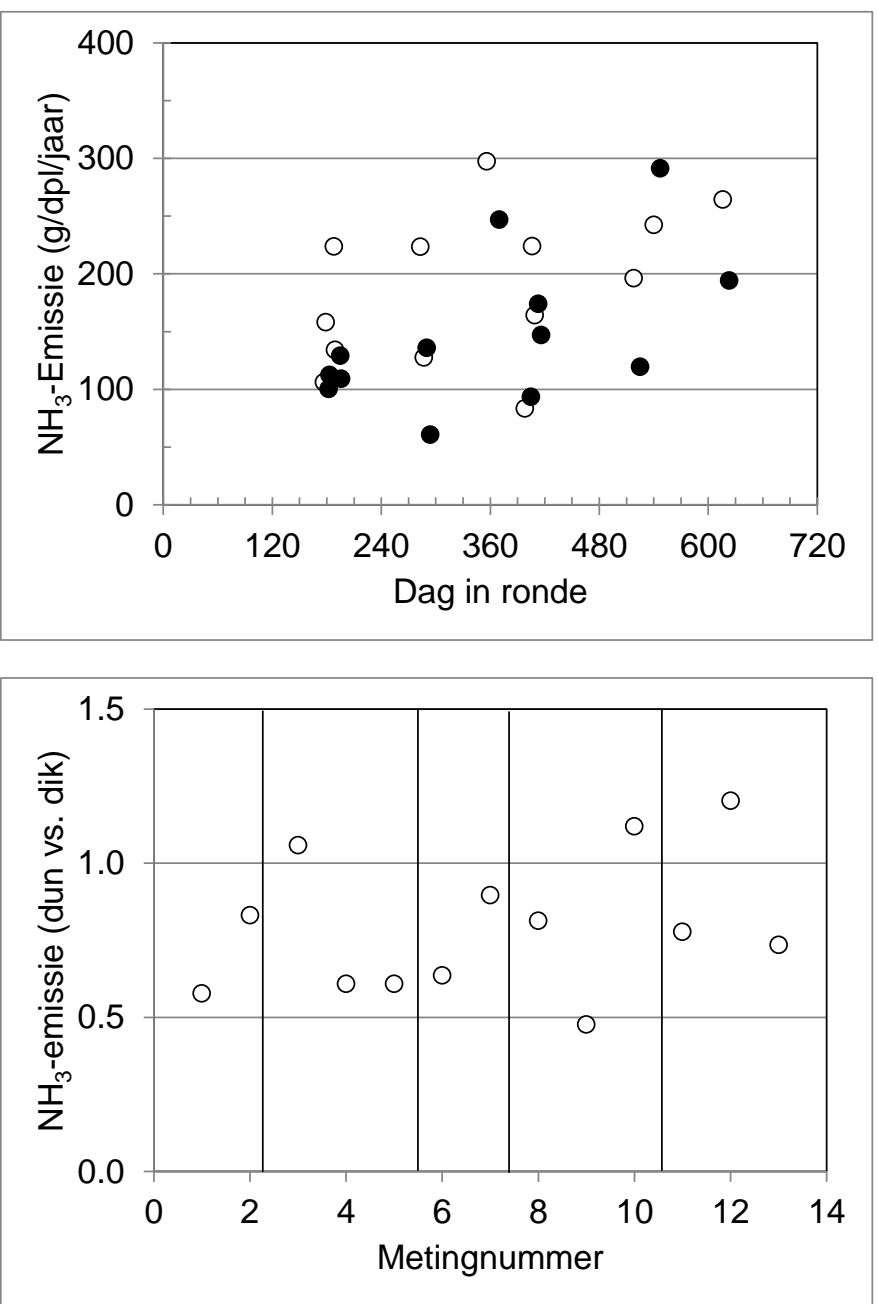

Figuur 10 Boven: gemiddelde $\mathrm{NH}_{3}$-emissie op alle verschillende meetdagen. dpl: geplaatste dieren. Open symbolen: emissie vóór het verwijderen van strooisel (controle); Gesloten symbolen: emissie na verwijdering van strooisel (case). Onder: verhouding tussen de $\mathrm{NH}_{3}$-emissie na het verwijderen van strooisel (case) en de emissies vóór het verwijderen van strooisel (controle). De verticale lijnen worden gebruikt om onderscheid te maken tussen de metingen bij de verschillende meetlocaties. 
Emissies na verwijdering van strooisel (case) waren zwak significant $(0,05<\mathrm{P}<0,10)$ verschillend t.o.v. de emissies vóór verwijdering van strooisel (controle). De gemiddelde $\mathrm{NH}_{3}$-emissiereductie door het verwijderen van strooisel in de stal over alle metingen was in onderhavige studie $20 \pm 6 \%$ (figuur 10) bij een reductie van de strooisel-laagdikte van $4 \mathrm{~cm}$ (ammoniakemissiereductie van $5 \%$ per $\mathrm{cm}$ ). Dit is vergelijkbaar met de emissiereductie gerapporteerd door Groot Koerkamp en Reitsma (1997). In die studie, ook bij legkippen op een volièresysteem, werd de strooisel-laag gehalveerd (van 9,2 naar $4,7 \mathrm{~cm}$ ). Het directe effect van het strooisel verwijderen op de $\mathrm{NH}_{3}$-emissie werd door Groot Koerkamp en Reitsma (1997) op $24 \%$ geschat, oftewel een reductie in ammoniakemissie van $5 \%$ per cm. Groot Koerkamp en Reitsma (1997) geven aan dat een verdere reductie in $\mathrm{NH}_{3}$-emissie mogelijk is, wanneer een dunnere strooisel-laag kan worden gerealiseerd.

Eind 2012 zijn door Van Emous et al. (2009) indicatieve metingen gedaan op 2 praktijkbedrijven met volière legkippenbedrijven om het effect van een dunnere strooisel-laag op de $\mathrm{NH}_{3}$-emissie te bepalen. De resultaten waren niet eenduidig. Op een bedrijf (volièrestal met 2 etages), waarbij een verlaging van de strooisel-laag van gemiddeld 7 naar $2 \mathrm{~cm}$ gerealiseerd kon worden, werd een reductie op de $\mathrm{NH}_{3}$-emissie van $65 \%$ gemeten. Bij de tweede bedrijf (bedrijf met 2 verschillende volièrestallen), waren de verschillen in $\mathrm{NH}_{3}$-emissie van een dunnere strooisel-laag t.o.v. de referentie (dikkere laag) niet significant. Dit werd verklaard door verschillen in leeftijd van de dieren tussen de stallen, en doordat de strooisel-laag niet voldoende kon worden verlaagd (van gemiddeld 9,8 naar 3,6 cm).

Figuur 11 laat zien dat de dikte van de strooisel-laag na het verwijderen van de strooisel belangrijker is dan de hoeveelheid strooisel die verwijderd wordt om $\mathrm{NH}_{3}$-emissies te kunnen reduceren. Een voorbeeld is meting 2 bij locatie 5, waar meer dan $5 \mathrm{~cm}$ dikte van de strooisel-laag werd verwijderd maar waar de dikte van de strooisel-laag na verwijdering nog steeds bijna $4 \mathrm{~cm}$ was. In dit geval werden hogere $\mathrm{NH}_{3}$-emissies gemeten na verwijdering van het strooisel (case) t.o.v. van de controle. Geconcludeerd kan worden dat om $\mathrm{NH}_{3}$-emissies te kunnen reduceren, de dikte van de strooisel-laag na verwijdering kleiner dan 2-3 cm moet zijn. In dat geval kan een $\mathrm{NH}_{3}$-emissiereductie van $25-30 \%$ worden bereikt. 

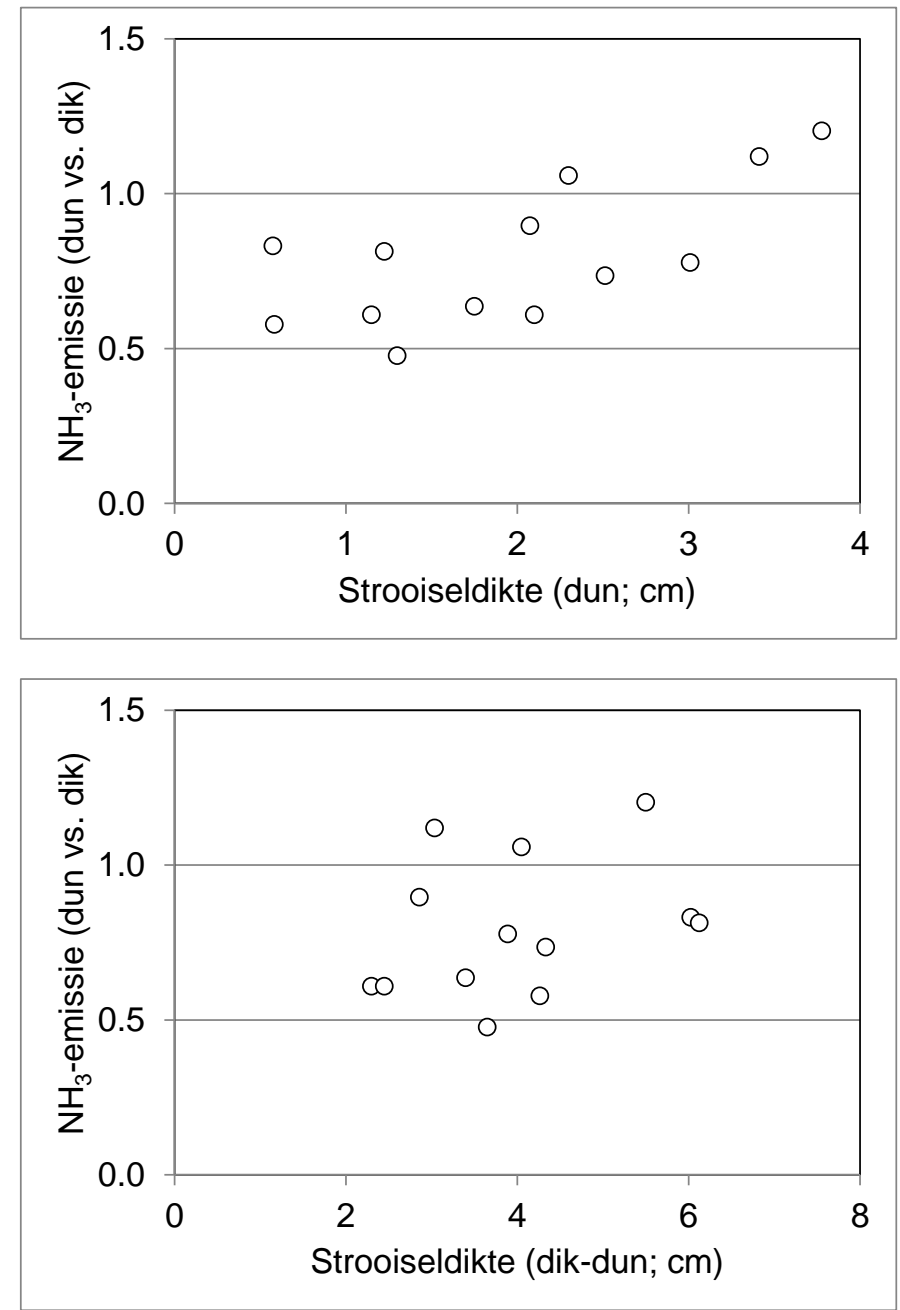

Figuur 11 Verhouding tussen de $\mathrm{NH}_{3}$-emissie na het verwijderen van strooisel (case) en de emissies vóór het verwijderen van strooisel (controle). Boven: relatie t.o.v. de dikte van de strooisel-laag na het verwijderen van strooisel. Onder: relatie t.o.v. het verschil in dikte tussen case en controle.

\subsection{Fijnstof (PM10)}

In figuur 12 worden de PM10-emissies en de gemeten emissiereducties weergegeven. De meetdata bevatte geen uitbijters. De veel hogere ventilatie bij meting 1 op locatie 2 tijdens de metingen met een dunne strooisel-laag t.o.v. van de metingen bij een dikkere strooisel-laag heeft niet geleid tot extreem hogere PM10-emissies. Gemiddeld over alle metingen (tabel 7 en figuur 12) was de PM10emissie 57,3 $\pm 33,8 \mathrm{~g} / \mathrm{jaar}$ per geplaatst dier (emissies gecorrigeerd door $4 \%$ leegstand) in de meetperioden met een dikke strooisel-laag, en 41,6 $\pm 20,2 \mathrm{~g} / \mathrm{jaar}$ per geplaatst dier (emissies gecorrigeerd door $4 \%$ leegstand) in de meetperioden met een dunne strooisel-laag. De gemiddelde emissie over alle metingen (dikke en dunne strooisel-laag) was 51,5 $\pm 29,6 \mathrm{~g} / \mathrm{jaar}$ per geplaatst dier (emissies gecorrigeerd door 4\% leegstand). Dit is iets lager dan de emissies $(64,6 \pm 13,2 \mathrm{~g} / \mathrm{jaar}$ per geplaatst dier; emissies gecorrigeerd door 4\% leegstand) gerapporteerd in Winkel e.a. (2011) bij metingen aan vier bedrijven met leghennen in volièrehuisvesting en de emissiefactoren in de Rav voor volièrehuisvesting met mestbanden en mestbeluchting (65/jaar per geplaatst dier). De gemiddelde emissie in Winkel e.a. (2011) was gebaseerd op 22 metingen verdeeld over het gehele jaar. 

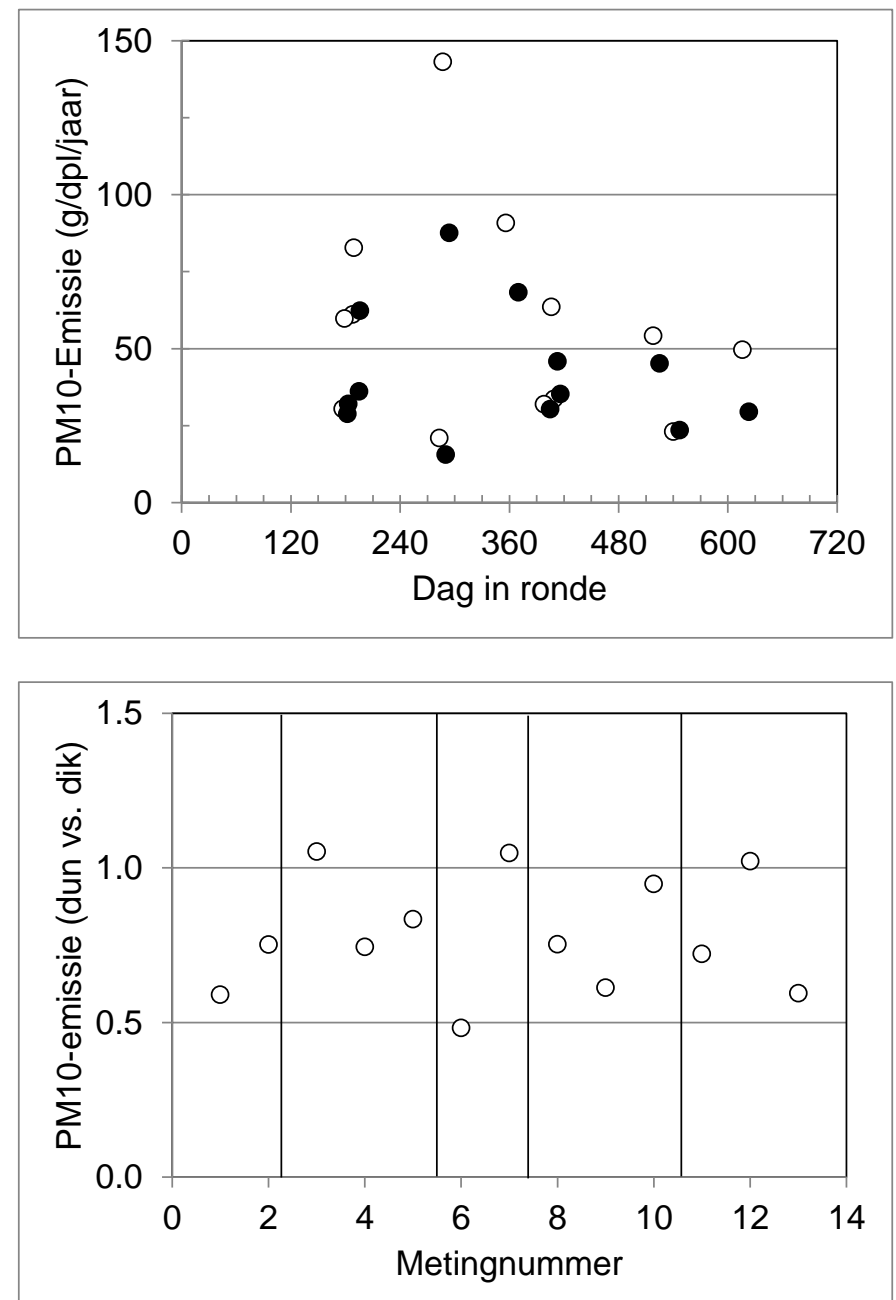

Figuur 12 Boven: gemiddelde PM10-emissie op alle verschillende meetdagen. dpl: geplaatste dieren. Open symbolen: emissie vóór het verwijderen van strooisel (controle); Gesloten symbolen: emissie na verwijdering van strooisel (case). Onder: verhouding tussen de PM10-emissie na het verwijderen van strooisel (case) en de emissies vóór het verwijderen van strooisel (controle). De verticale lijnen worden gebruikt om onderscheid te maken tussen de metingen bij de verschillende meetlocaties.

Emissies na verwijdering van strooisel (case) waren zwak significant $(0,05<P<0,10)$ verschillend t.o.v. de emissies vóór verwijdering van strooisel (controle). De gemiddelde PM10-emissiereductie door het verwijderen van strooisel in de stal over alle metingen was in onderhavige studie $22 \pm 5 \%$ (figuur 12) bij een reductie van de strooisel-laagdikte van $4 \mathrm{~cm}$ (PM10-emissiereductie van $5 \%$ per $\mathrm{cm}$ ). In een literatuurstudie van Van Emous et al. (2009) werd geconcludeerd dat het verlagen van de strooisel-laag dikte van 10 naar $5 \mathrm{~cm}$ nauwelijks effect zou hebben op de fijnstofemissie. Echter, door de strooisel-laag van 10 naar $2 \mathrm{~cm}$ te reduceren zou een reductie van de fijnstofemissie van $50 \%$ gerealiseerd kunnen worden. Eind 2012 zijn door Van Emous et al. (2009) indicatieve metingen gedaan op 2 praktijkbedrijven met volière legkippenbedrijven om het effect van een dunnere strooisellaag op de PM10-emissie te bepalen. De resultaten waren niet eenduidig. Op een bedrijf (volièrestal met 2 etages), waarbij een verlaging van de strooisel-laag van gemiddeld 7 naar $2 \mathrm{~cm}$ gerealiseerd kon worden, werd een reductie op de PM10-emissie van 37\% gemeten. Bij de tweede bedrijf (bedrijf met 2 verschillende volièrestallen), waren de verschillen in PM10-emissie van een dunnere strooisellaag t.o.v. de referentie (dikkere laag) niet significant. Dit werd verklaard door verschillen in leeftijd van de dieren tussen de stallen, en doordat de strooisel-laag niet voldoende kon worden verlaagd (van gemiddeld 9,8 naar 3,6 cm). 
Figuur 13 laat zien dat, net zoals voor $\mathrm{NH}_{3}$, de dikte van de strooisel-laag na het verwijderen van de strooisel belangrijker is dan de hoeveelheid strooisel die verwijderd wordt om PM10-emissies te kunnen reduceren: de reductie is groter wanneer de dikte van de strooisel-laag na verwijdering kleiner is dan 2-3 cm. In dit geval kan een PM10-emissiereductie van $25-35 \%$ worden bereikt.
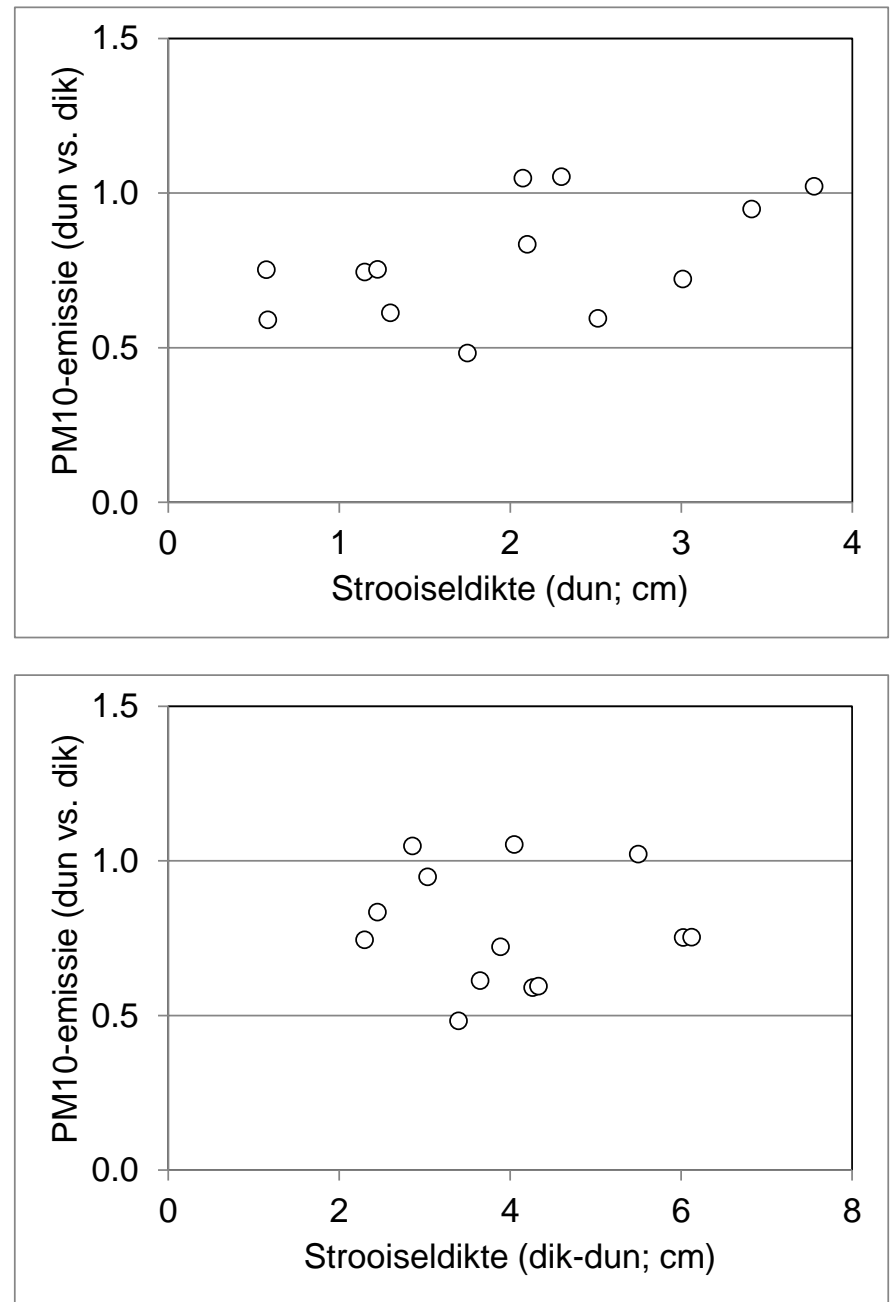

Figuur 13 Verhouding tussen de PM10-emissie na het verwijderen van strooisel (case) en de emissies vóór het verwijderen van strooisel (controle). Boven: relatie t.o.v. de dikte van de strooisel-laag na het verwijderen van strooisel. Onder: relatie t.o.v. het verschil in dikte tussen case en controle. 


\subsection{Geur}

In figuur 14 worden de geuremissies en de gemeten emissiereducties weergegeven. Hoewel bij meting 2 op locatie 1 een veel hogere emissie na strooiselverwijdering t.o.v. vóór verwijdering werd gemeten, en bij meting 2 op locatie 4 juist een veel lagere emissie na strooiselverwijdering t.o.v. vóór verwijdering, konden geen uitbijters in de meetdata aangetoond worden. Gemiddeld over alle metingen (Tabel 7 en Figuur 14) was de geuremissie 0,51 $\pm 0,12 \mathrm{OU}_{\mathrm{E}} / \mathrm{s}$ per geplaatst dier (emissies worden voor geur niet gecorrigeerd voor leegstand) in de meetperioden met een dikke strooisel-laag, en 0,44 $\pm 0,22 \mathrm{OU}_{\mathrm{E}} / \mathrm{s}$ per geplaatst dier in de meetperioden met een dunne strooisel-laag. Opvallend was ook dat bij locaties 1 en 2 de geuremissie in de case (na verwijdering van strooisel) over het algemeen hoger waren dan in de controle (dikkere strooisel-laag). Bij locaties $3 \mathrm{t} / \mathrm{m} 5$ werden altijd lagere geuremissies gemeten in de case t.o.v. de controle. Het was binnen dit project niet mogelijk om een verklaring voor dit effect te vinden.

De gemiddelde emissie (zonder correctie voor leegstand) over alle metingen (dikke en dunne strooisel-laag) was $0,47 \pm 0,17 \mathrm{OU}_{\mathrm{E}} / \mathrm{s}$ per geplaatst dier. Dit is hoger dan de emissies $(0,20 \pm 0,04$ $\mathrm{OU}_{\mathrm{E}} / \mathrm{s}$ per geplaatst dier) gerapporteerd in Winkel e.a. (2011) bij metingen aan vier bedrijven met leghennen in volièrehuisvesting, en eveneens hoger dan de huidige emissiefactor in de Rav voor volièrehuisvesting met mestbanden en mestbeluchting $\left(0,34 \mathrm{OU}_{\mathrm{E}} / \mathrm{s}\right.$ per geplaatst dier). De gemiddelde emissie in Winkel e.a. (2011) was gebaseerd op 22 metingen verdeeld over het gehele jaar.
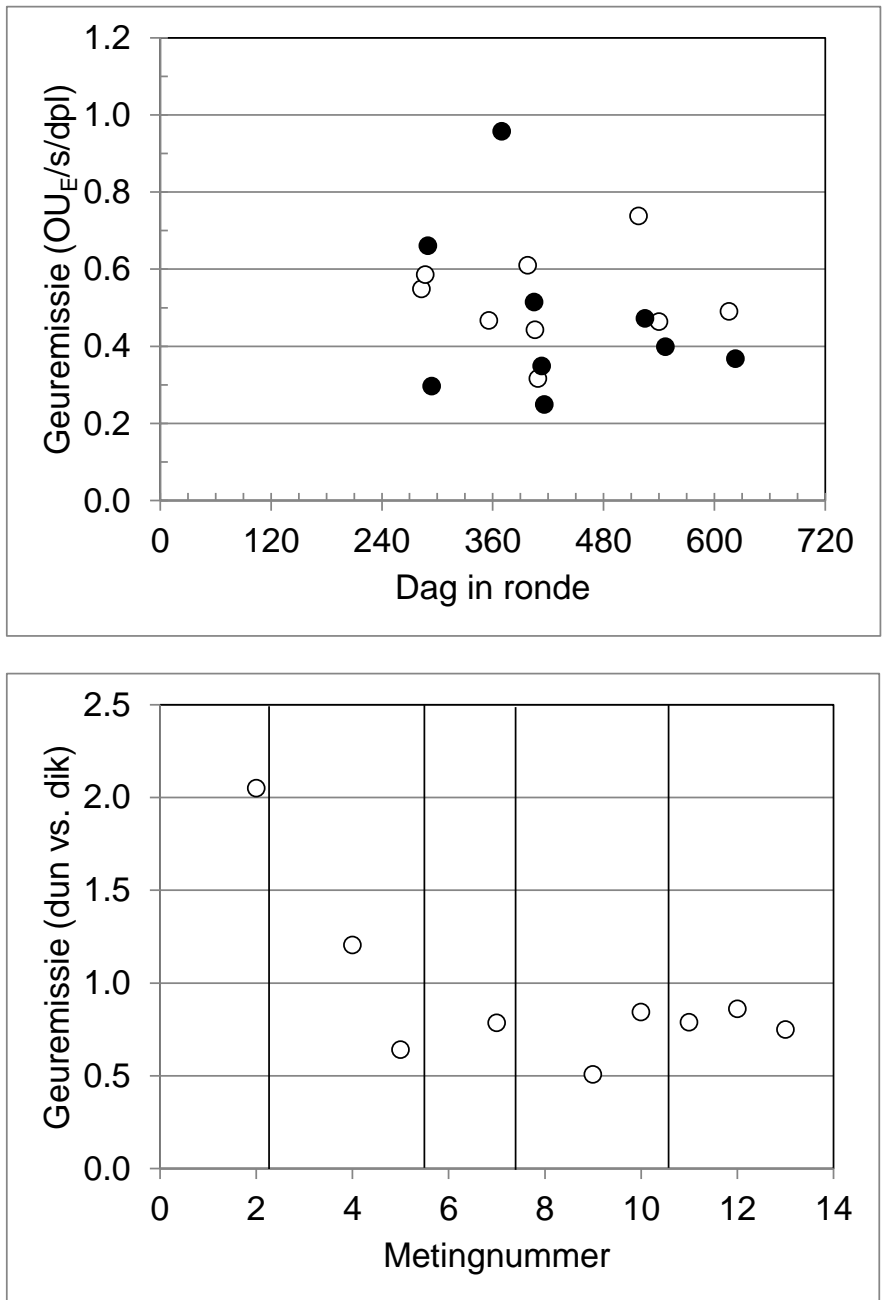

Figuur 14 Boven: gemiddelde geuremissie op alle verschillende meetdagen. dpl: geplaatste dieren. Open symbolen: emissie vóór het verwijderen van strooisel (controle); Gesloten symbolen: emissie na verwijdering van strooisel (case). Onder: verhouding tussen de geuremissie na het verwijderen van strooisel (case) en de emissies vóór het verwijderen van strooisel (controle). De verticale lijnen worden gebruikt om onderscheid te maken tussen de metingen bij de verschillende meetlocaties. 
De gemiddelde geuremissiereductie door het verwijderen van strooisel in de stal over alle metingen was in onderhavige studie $6 \pm 15 \%$ (figuur 14) bij een reductie van de strooisel-laagdikte van $4 \mathrm{~cm}$, hoewel dit effect niet statistisch significant was $(P>0,10)$. De eerste twee metingen laten een afwijkend patroon zien (hogere in plaats van lagere geuremissies na verwijderen van het strooisel) ten opzichte van de andere zeven metingen. Hiervoor is geen verklaring gevonden. Een statistische analyse heeft ook laten zien dat deze metingen niet als uitbijter kunnen worden beschouwd. Echter, de laatste zeven metingen laten zien dat strooiselverwijdering potentie heeft om geuremissies sterk te kunnen reduceren. De gemiddelde emissiereductie van deze zeven metingen is $26 \pm 5 \%$, en het effect is sterk significant $(P<0,05)$. Figuur 15 laat geen direct verband zien tussen de geuremissie en de dikte van de strooisel-laag na het verwijderen van de strooisel, en tussen de geuremissie en de hoeveelheid strooisel die verwijderd wordt.
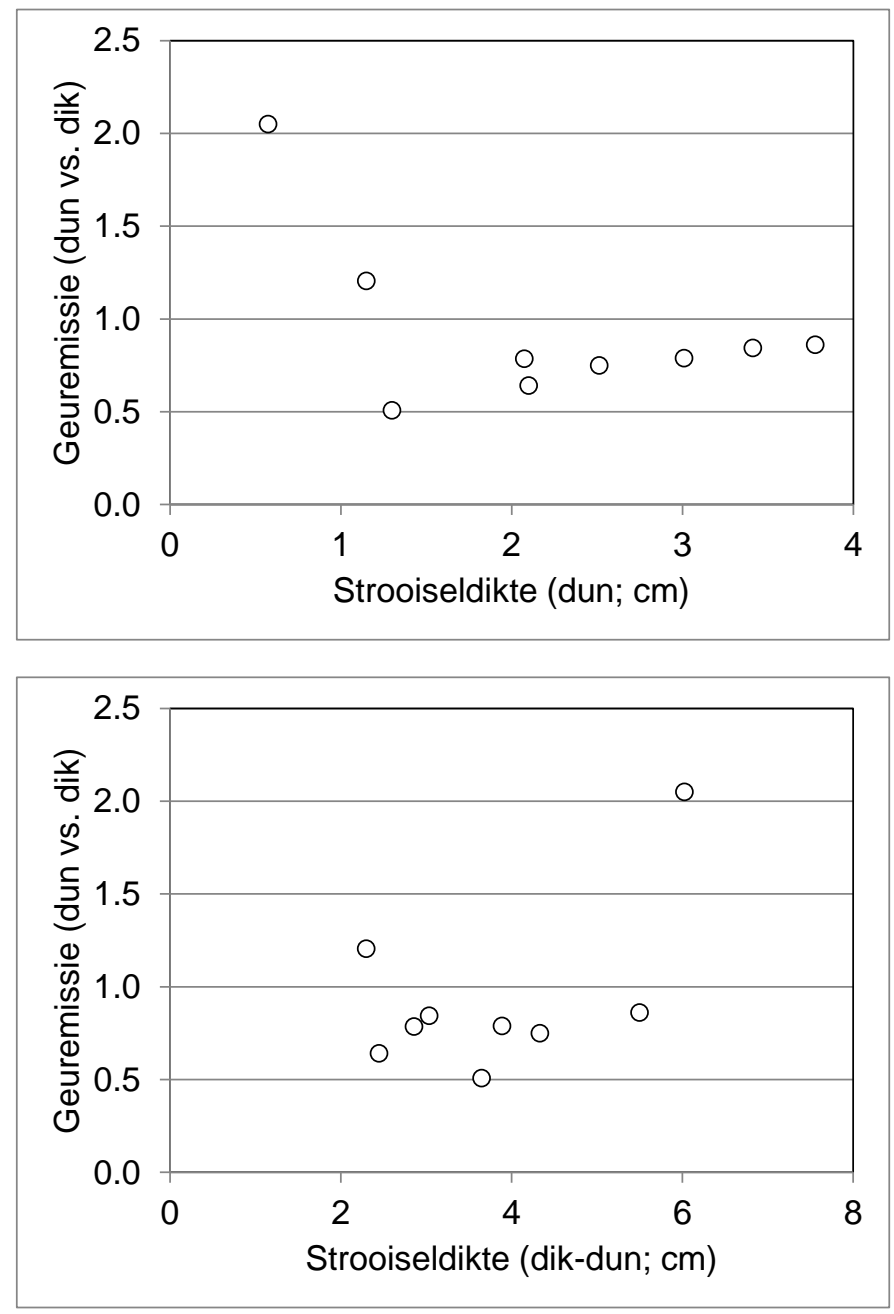

Figuur 15 Verhouding tussen de geuremissie na het verwijderen van strooisel (case) en de emissies vóór het verwijderen van strooisel (controle). Boven: relatie t.o.v. de dikte van de strooisel-laag na het verwijderen van strooisel. Onder: relatie t.o.v. het verschil in dikte tussen case en controle. 


\subsection{Methaan $\left(\mathrm{CH}_{4}\right)$}

In figuur 16 worden de $\mathrm{CH}_{4}$-emissies en de gemeten emissiereducties weergegeven. De meetdata bevatte geen uitbijters. Gemiddeld over alle metingen (tabel 7 en figuur 16 ) bedroeg de $\mathrm{CH}_{4}$-emissie $14,5 \pm 6,3 \mathrm{~g} /$ jaar per geplaatst dier (emissies gecorrigeerd door $4 \%$ leegstand) in de meetperioden met een dikke strooisel-laag, en 15,1 $\pm 5,3 \mathrm{~g} / \mathrm{jaar}$ per geplaatst dier in de meetperioden met een dunne strooisel-laag. De gemiddelde emissie (gecorrigeerd door $4 \%$ leegstand) over alle metingen (dikke en dunne strooisel-laag) was 15,4 $\pm 5,9 \mathrm{~g} / \mathrm{jaar}$ per geplaatst dier. Dit is lager dan de emissies (26,2 $\pm 10,2 \mathrm{~g} /$ jaar per geplaatst dier) gerapporteerd in Winkel e.a. (2011) bij metingen aan vier bedrijven met leghennen in volièrehuisvesting. De gemiddelde emissie in Winkel e.a. (2011) was gebaseerd op 22 metingen verdeeld over het gehele jaar.
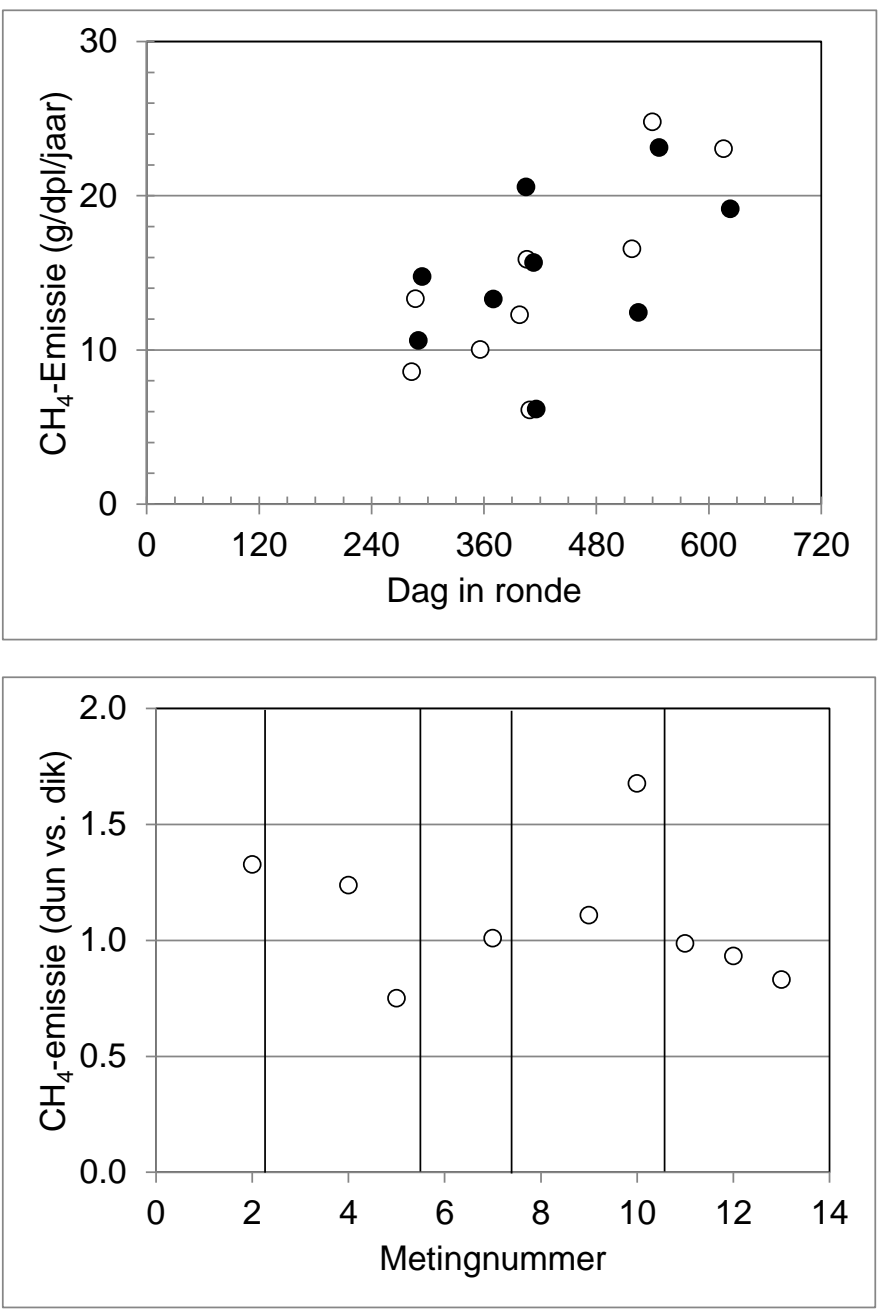

Figuur 16 Boven: gemiddelde $\mathrm{CH}_{4}$-emissie op alle verschillende meetdagen. dpl: geplaatste dieren. Open symbolen: emissie vóór het verwijderen van strooisel (controle); Gesloten symbolen: emissie na verwijdering van strooisel (case). Onder: verhouding tussen de $\mathrm{CH}_{4}$-emissie na het verwijderen van strooisel (case) en de emissies vóór het verwijderen van strooisel (controle). De verticale lijnen worden gebruikt om onderscheid te maken tussen de metingen bij de verschillende meetlocaties.

De data laat over alle metingen geen $\mathrm{CH}_{4}$-emissiereductie maar een geringe toename (10 $\pm 9 \%$ ) van de $\mathrm{CH}_{4}$-emissies door het verwijderen van strooisel in de stal (figuur 16), hoewel dit effect niet statistisch significant was $(P>0,10)$. Figuur 17 laat geen direct verband zien met de dikte van de strooisel-laag na het verwijderen van de strooisel of met de hoeveelheid strooisel die verwijderd wordt. 

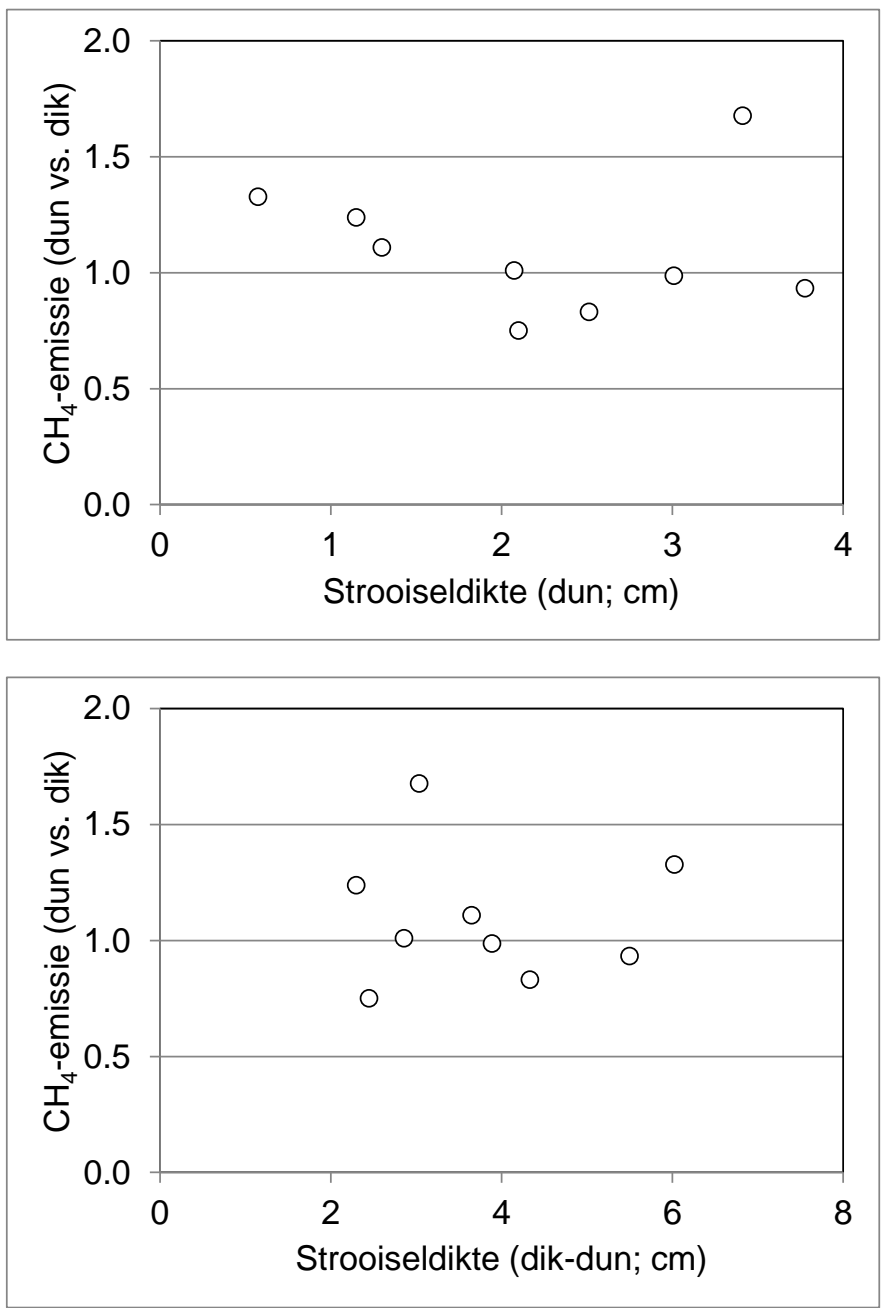

Figuur 17 Verhouding tussen de $\mathrm{CH}_{4}$-emissie na het verwijderen van strooisel (case) en de emissies vóór het verwijderen van strooisel (controle). Boven: relatie t.o.v. de dikte van de strooisel-laag na het verwijderen van strooisel. Onder: relatie t.o.v. het verschil in dikte tussen case en controle. 


\subsection{Lachgas $\left(\mathrm{N}_{2} \mathrm{O}\right)$}

In figuur 16 worden de $\mathrm{N}_{2} \mathrm{O}$-emissies en de gemeten emissiereducties weergegeven. De meetdata bevatte geen uitbijters. Gemiddeld over alle metingen (tabel 7 en figuur 18 ) bedroeg de $\mathrm{N}_{2} \mathrm{O}$-emissie $0,44 \pm 0,30 \mathrm{~g} / \mathrm{jaar}$ per geplaatst dier (emissies gecorrigeerd door $4 \%$ leegstand) in de meetperioden met een dikke strooisel-laag, en 0,31 $\pm 0,23 \mathrm{~g} / \mathrm{jaar}$ per geplaatst dier in de meetperioden met een dunne strooisel-laag. De gemiddelde emissie (gecorrigeerd door $4 \%$ leegstand) over alle metingen (dikke en dunne strooisel-laag) was 0,39 $\pm 0,28 \mathrm{~g} / \mathrm{jaar}$ per geplaatst dier. Dit is beduidend lager dan de emissies (10,8 \pm 3,9 g/jaar per geplaatst dier) gerapporteerd in Winkel e.a. (2011) bij metingen aan vier bedrijven met leghennen in volièrehuisvesting. De gemiddelde emissie in Winkel e.a. (2011) was gebaseerd op 22 metingen verdeeld over het gehele jaar.
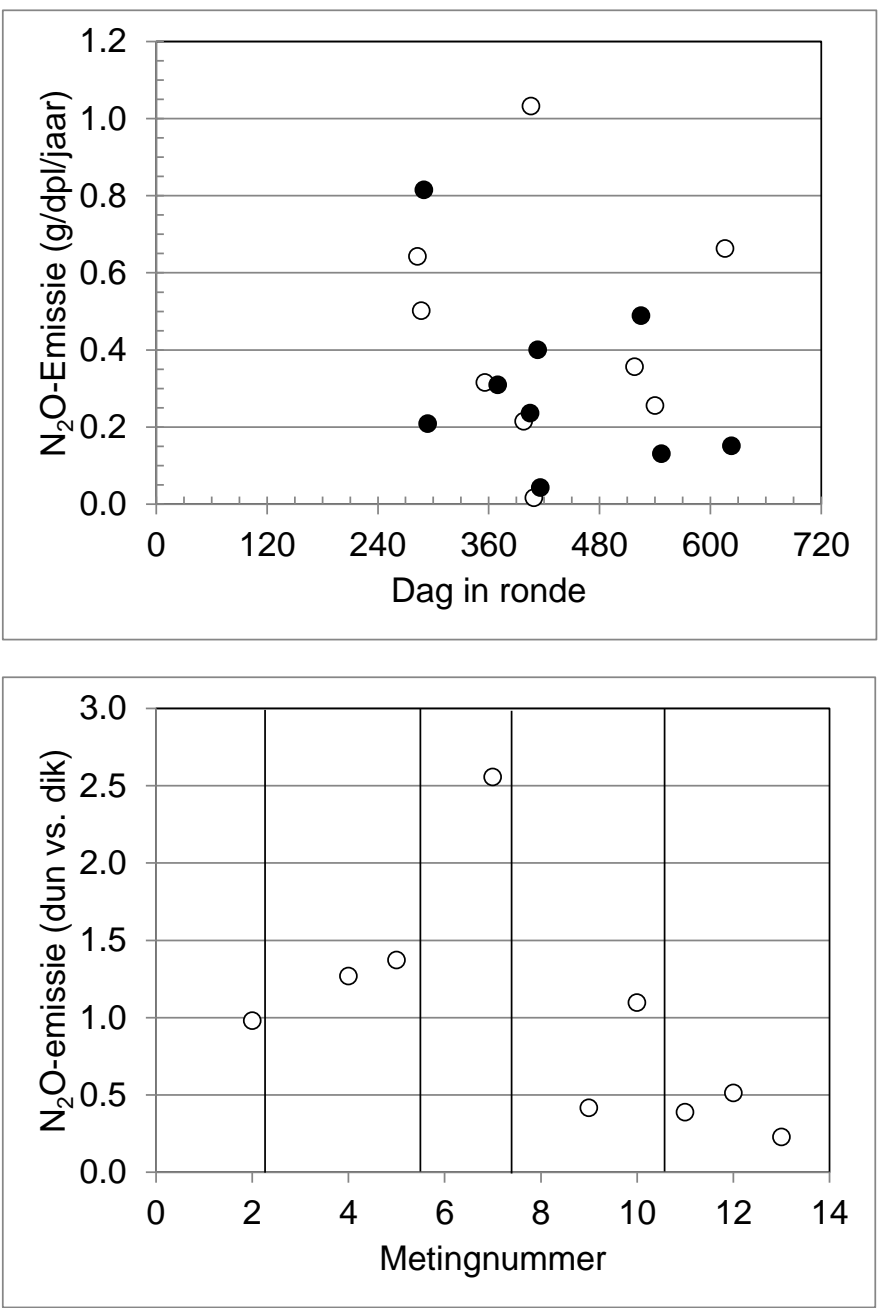

Figuur 18 Boven: gemiddelde $\mathrm{N}_{2} \mathrm{O}$-emissie op alle verschillende meetdagen. dpl: geplaatste dieren. Open symbolen: emissie vóór het verwijderen van strooisel (controle); Gesloten symbolen: emissie na verwijdering van strooisel (case). Onder: verhouding tussen de $\mathrm{N}_{2} \mathrm{O}$-emissie na het verwijderen van strooisel (case) en de emissies vóór het verwijderen van strooisel (controle). De verticale lijnen worden gebruikt om onderscheid te maken tussen de metingen bij de verschillende meetlocaties.

De gemiddelde $\mathrm{N}_{2} \mathrm{O}$-emissiereductie door het verwijderen van strooisel in de stal over alle metingen was in onderhavige studie $2 \pm 24 \%$ (figuur 14). Dit effect wijkt niet significant af van nul $(P>0,10)$. Figuur 19 laat geen directe verband zien met de dikte van de strooisel-laag na het verwijderen van de strooisel, of met de hoeveelheid strooisel die verwijderd wordt. 

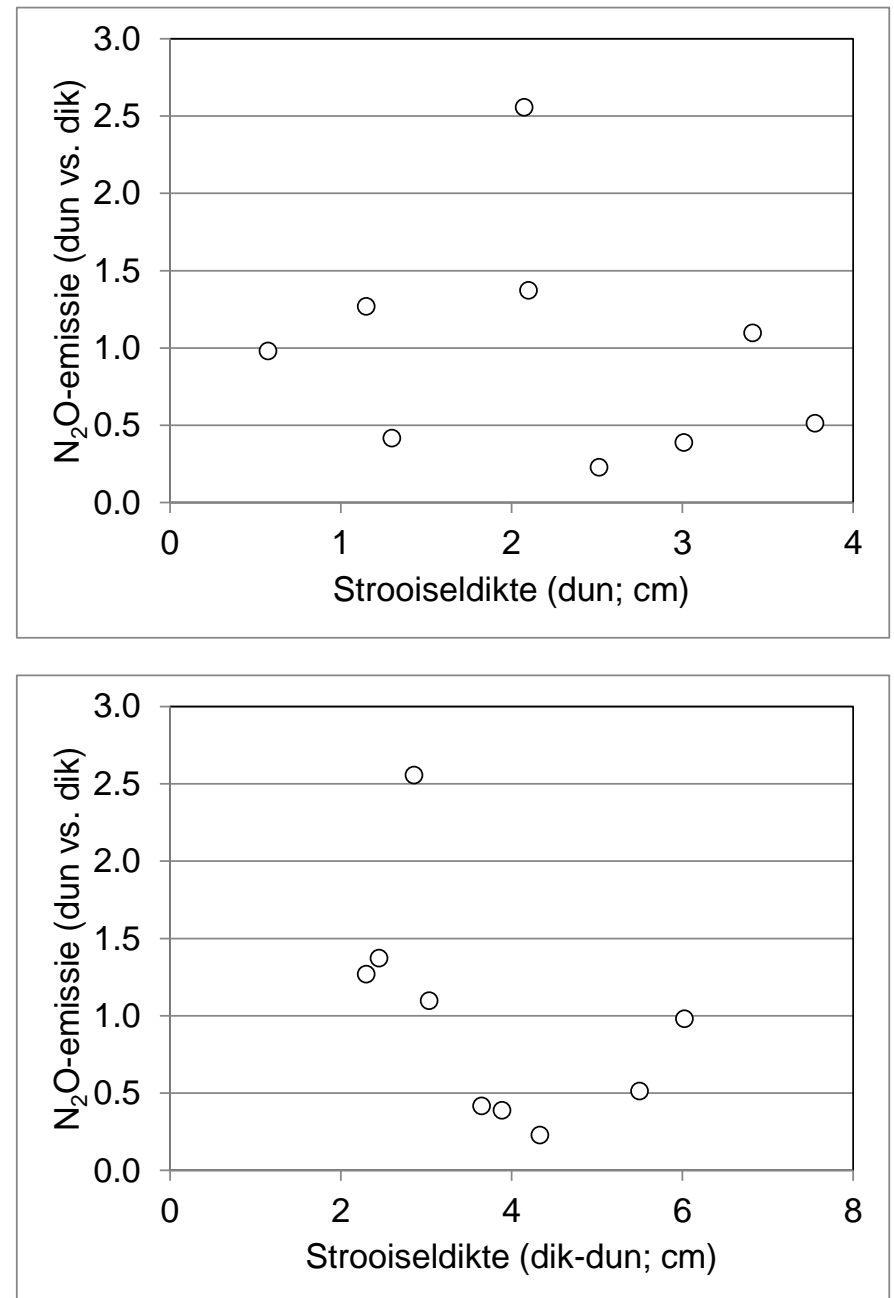

Figuur 19 Verhouding tussen de $\mathrm{N}_{2} \mathrm{O}$-emissie na het verwijderen van strooisel (case) en de emissies vóór het verwijderen van strooisel (controle). Boven: relatie t.o.v. de dikte van de strooisel-laag na het verwijderen van strooisel. Onder: relatie t.o.v. het verschil in dikte tussen case en controle. 


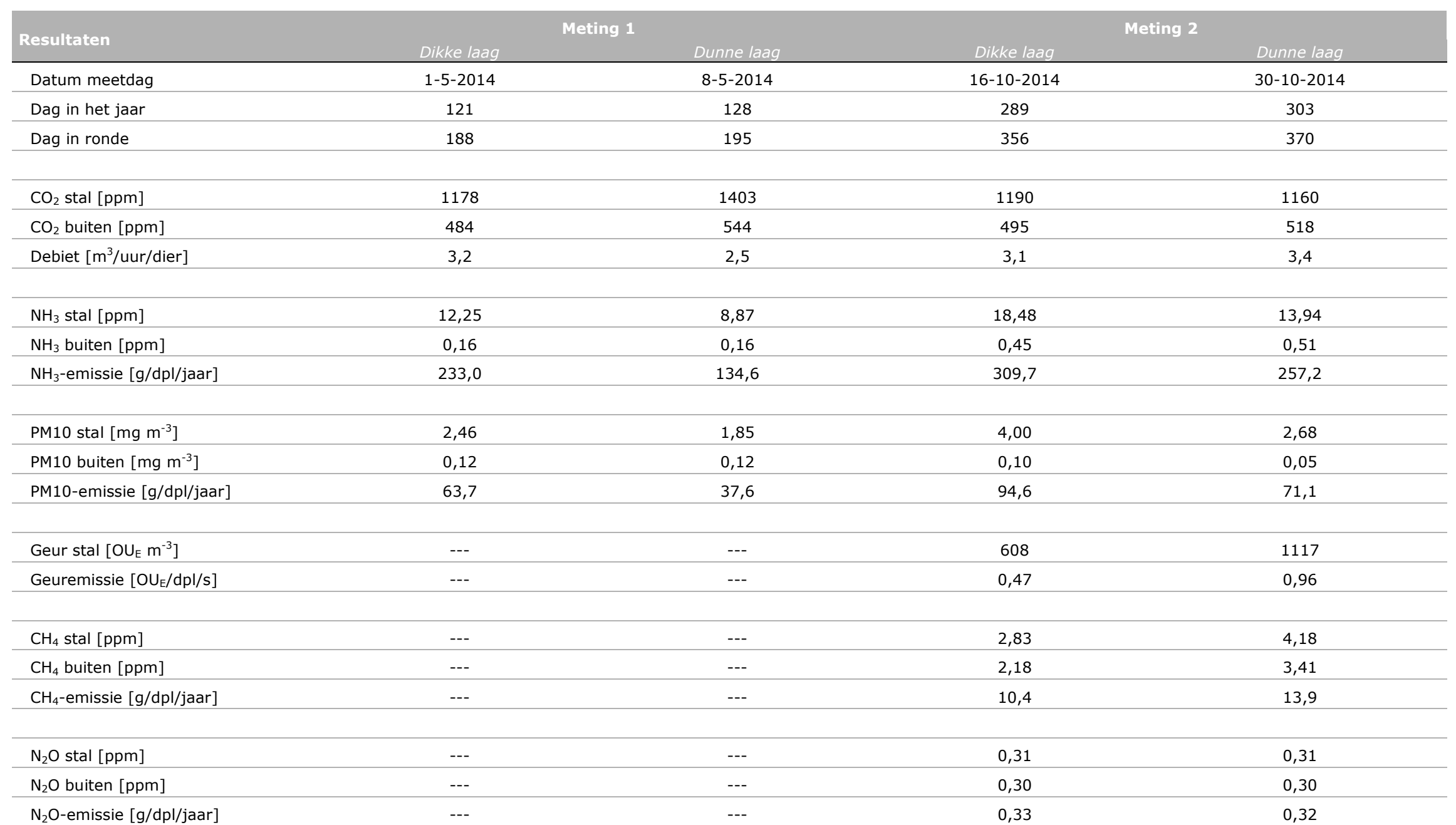




\begin{tabular}{|c|c|c|c|c|c|c|}
\hline \multirow{2}{*}{ Resultaten } & \multicolumn{2}{|c|}{ Meting 1} & \multicolumn{2}{|c|}{ Meting 2} & \multicolumn{2}{|c|}{ Meting 3} \\
\hline & Dikke laag & Dunne laag & Dikke laag & Dunne laag & Dikke laag & Dunne laag \\
\hline Datum meetdag & $15-5-2014$ & $21-5-2014$ & $19-10-2015$ & $26-10-2015$ & $10-6-2016$ & $17-6-2016$ \\
\hline Dag in het jaar & 135 & 141 & 292 & 299 & 162 & 169 \\
\hline Dag in ronde & 177 & 183 & 283 & 290 & 518 & 525 \\
\hline $\mathrm{CO}_{2}$ stal $[\mathrm{ppm}]$ & 2000 & 800 & 1421 & 1373 & 819 & 1173 \\
\hline $\mathrm{CO}_{2}$ buiten $[\mathrm{ppm}]$ & 611 & 516 & 437 & 421 & 385 & 411 \\
\hline Debiet [m³/uur/dier] & 1,6 & 7,1 & 2,1 & 2,2 & 4,7 & 2,9 \\
\hline $\mathrm{NH}_{3}$ stal $[\mathrm{ppm}]$ & 11,71 & 2,82 & 18,06 & 10,77 & 7,41 & 7,43 \\
\hline $\mathrm{NH}_{3}$ buiten $[\mathrm{ppm}]$ & 0,08 & 0,09 & 0,07 & 0,09 & 0,10 & 0,14 \\
\hline $\mathrm{NH}_{3}$-emissie [g/dpl/jaar] & 110,6 & 117,0 & 232,7 & 141,6 & 204,3 & 124,4 \\
\hline PM10 stal $\left[\mathrm{mg} \mathrm{m}^{-3}\right]$ & 2,40 & 0,61 & 1,21 & 0,88 & 1,44 & 2,01 \\
\hline PM10 buiten $\left[\mathrm{mg} \mathrm{m}^{-3}\right]$ & 0,04 & 0,06 & 0,02 & 0,01 & 0,01 & 0,06 \\
\hline PM10-emissie [g/dpl/jaar] & 31,7 & 33,4 & 21,8 & 16,2 & 56,4 & 47,1 \\
\hline Geur stal $\left[O U_{E} m^{-3}\right]$ & --- & --- & 948 & 1113 & 590 & 618 \\
\hline Geuremissie $\left[O U_{E} / \mathrm{dpl} / \mathrm{s}\right]$ & --- & --- & 0,55 & 0,66 & 0,74 & 0,47 \\
\hline $\mathrm{CH}_{4}$ stal $[\mathrm{ppm}]$ & --- & --- & 3,15 & 3,01 & 2,52 & 2,99 \\
\hline $\mathrm{CH}_{4}$ buiten $[\mathrm{ppm}]$ & --- & --- & 2,42 & 2,12 & 1,87 & 2,19 \\
\hline $\mathrm{CH}_{4}$-emissie $[\mathrm{g} / \mathrm{dpl} / \mathrm{jaar}]$ & --- & --- & 8,9 & 11,1 & 17,2 & 12,9 \\
\hline $\mathrm{N}_{2} \mathrm{O}$ stal $[\mathrm{ppm}]$ & --- & --- & 0,32 & 0,32 & 0,36 & 0,40 \\
\hline $\mathrm{N}_{2} \mathrm{O}$ buiten $[\mathrm{ppm}]$ & --- & --- & 0,30 & 0,29 & 0,35 & 0,39 \\
\hline $\mathrm{N}_{2} \mathrm{O}$-emissie $[\mathrm{g} / \mathrm{dpl} / \mathrm{jaar}]$ & --- & --- & 0,67 & 0,85 & 0,37 & 0,51 \\
\hline
\end{tabular}




\begin{tabular}{|c|c|c|c|c|}
\hline \multirow{2}{*}{ Resultaten } & \multicolumn{2}{|c|}{ Meting 1} & \multicolumn{2}{|c|}{ Meting 2} \\
\hline & Dikke laag & Dunne laag & Dikke laag & Dunne laag \\
\hline Datum meetdag & $17-6-2014$ & $20-6-2014$ & 2-2-2015 & $9-2-2015$ \\
\hline Dag in het jaar & 168 & 171 & 33 & 40 \\
\hline Dag in ronde & 179 & 182 & 409 & 416 \\
\hline $\mathrm{CO}_{2}$ stal $[\mathrm{ppm}]$ & 1115 & 1070 & 2342 & 1943 \\
\hline $\mathrm{CO}_{2}$ buiten $[\mathrm{ppm}]$ & 541 & 559 & 577 & 638 \\
\hline $\mathrm{NH}_{3}$ stal $[\mathrm{ppm}]$ & 8,30 & 5,23 & 26,73 & 19,17 \\
\hline $\mathrm{NH}_{3}$ buiten $[\mathrm{ppm}]$ & 0,20 & 0,66 & 1,85 & 2,73 \\
\hline $\mathrm{NH}_{3}$-emissie $[\mathrm{g} / \mathrm{dpl} / \mathrm{jaar}]$ & 164,6 & 104,6 & 171,0 & 153,2 \\
\hline PM10 stal $\left[\mathrm{mg} \mathrm{m}^{-3}\right]$ & 2,37 & 1,44 & 3,83 & 2,86 \\
\hline PM10 buiten $\left[\mathrm{mg} \mathrm{m}^{-3}\right]$ & 0,20 & 0,51 & 0,22 & 0,07 \\
\hline Geur stal $\left[O U_{E} m^{-3}\right]$ & -- & --- & 1028 & 597 \\
\hline Geuremissie $\left[\mathrm{OU}_{\mathrm{E}} / \mathrm{dpl} / \mathrm{s}\right]$ & -- & -- & 0,32 & 0,25 \\
\hline $\mathrm{CH}_{4}$ stal $[\mathrm{ppm}]$ & --- & --- & 2,93 & 2,63 \\
\hline $\mathrm{CH}_{4}$ buiten $[\mathrm{ppm}]$ & --- & --- & 1,94 & 1,90 \\
\hline $\mathrm{CH}_{4}$-emissie $[\mathrm{g} / \mathrm{dpl} / \mathrm{jaar}]$ & -- & --- & 6,4 & 6,4 \\
\hline $\mathrm{N}_{2} \mathrm{O}$ stal $[\mathrm{ppm}]$ & --- & --- & 0,33 & 0,33 \\
\hline $\mathrm{N}_{2} \mathrm{O}$ buiten $[\mathrm{ppm}]$ & --- & --- & 0,33 & 0,32 \\
\hline $\mathrm{N}_{2} \mathrm{O}$-emissie $[\mathrm{g} / \mathrm{dpl} / \mathrm{jaar}]$ & --- & --- & 0,02 & 0,04 \\
\hline
\end{tabular}




\begin{tabular}{|c|c|c|c|c|c|c|}
\hline \multirow{2}{*}{ Resultaten } & \multicolumn{2}{|c|}{ Meting 1} & \multicolumn{2}{|c|}{ Meting 2} & \multicolumn{2}{|c|}{ Meting 3} \\
\hline & Dikke laag & Dunne laag & Dikke laag & Dunne laag & Dikke laag & Dunne laag \\
\hline Datum meetdag & $10-7-2014$ & $17-7-2014$ & $16-10-2014$ & $23-10-2014$ & 4-2-2015 & $11-2-2015$ \\
\hline Dag in het jaar & 191 & 198 & 289 & 296 & 35 & 42 \\
\hline Dag in ronde & 189 & 196 & 287 & 294 & 398 & 405 \\
\hline $\mathrm{CO}_{2}$ stal $[\mathrm{ppm}]$ & 814 & 812 & 1130 & 1300 & 2501 & 2195 \\
\hline $\mathrm{CO}_{2}$ buiten $[\mathrm{ppm}]$ & 470 & 476 & 564 & 502 & 494 & 524 \\
\hline Debiet $\left[\mathrm{m}^{3} / \mathrm{uur} / \mathrm{dier}\right]$ & 5,7 & 5,7 & 3,5 & 2,5 & 1,1 & 1,3 \\
\hline $\mathrm{NH}_{3}$ stal $[\mathrm{ppm}]$ & 4,25 & 3,39 & 8,12 & 4,78 & 14,42 & 13,54 \\
\hline $\mathrm{NH}_{3}$ buiten $[\mathrm{ppm}]$ & 0,26 & 0,14 & 1,67 & 0,44 & 0,25 & 0,22 \\
\hline $\mathrm{NH}_{3}$-emissie $[\mathrm{g} / \mathrm{dpl} / \mathrm{jaar}]$ & 139,7 & 113,7 & 132,8 & 63,3 & 87,0 & 97,3 \\
\hline PM10 stal $\left[\mathrm{mg} \mathrm{m}^{-3}\right]$ & 1,89 & 1,48 & 5,47 & 4,48 & 3,85 & 3,10 \\
\hline PM10 buiten $\left[\mathrm{mg} \mathrm{m}^{-3}\right]$ & 0,15 & 0,16 & 0,33 & 0,06 & 0,01 & 0,04 \\
\hline PM10-emissie [g/dpl/jaar] & 86,2 & 64,9 & 149,0 & 91,2 & 33,3 & 31,6 \\
\hline Geur stal $\left[\mathrm{OU}_{\mathrm{E}} \mathrm{m}^{-3}\right]$ & --- & --- & 636 & 454 & 2221 & 1573 \\
\hline Geuremissie $\left[O U_{E} / \mathrm{dpl} / \mathrm{s}\right]$ & --- & --- & 0,59 & 0,30 & 0,61 & 0,51 \\
\hline $\mathrm{CH}_{4}$ stal $[\mathrm{ppm}]$ & -- & -- & 3,05 & 3,74 & 4,43 & 5,01 \\
\hline $\mathrm{CH}_{4}$ buiten $[\mathrm{ppm}]$ & --- & --- & 2,33 & 2,63 & 2,22 & 1,89 \\
\hline $\mathrm{CH}_{4}$-emissie $[\mathrm{g} / \mathrm{dpl} / \mathrm{jaar}]$ & -- & -- & 13,9 & 15,4 & 12,8 & 21,4 \\
\hline $\mathrm{N}_{2} \mathrm{O}$ stal $[\mathrm{ppm}]$ & -- & -- & 0,32 & 0,33 & 0,32 & 0,32 \\
\hline $\mathrm{N}_{2} \mathrm{O}$ buiten [ppm] & --- & --- & 0,31 & 0,32 & 0,31 & 0,30 \\
\hline $\mathrm{N}_{2} \mathrm{O}$-emissie $[\mathrm{g} / \mathrm{dpl} / \mathrm{jaar}]$ & --- & --- & 0,52 & 0,22 & 0,22 & 0,25 \\
\hline
\end{tabular}




\begin{tabular}{|c|c|c|c|c|c|c|}
\hline \multirow{2}{*}{ Resultaten } & \multicolumn{2}{|c|}{ Meting 1} & \multicolumn{2}{|c|}{ Meting 2} & \multicolumn{2}{|c|}{ Meting 3} \\
\hline & Dikke laag & Dunne laag & Dikke laag & Dunne laag & Dikke laag & Dunne laag \\
\hline Datum meetdag & $10-7-2014$ & $17-7-2014$ & $16-10-2014$ & $23-10-2014$ & 4-2-2015 & $11-2-2015$ \\
\hline Datum meetdag & $16-11-2015$ & 23-11-2015 & $29-3-2016$ & $5-4-2016$ & $13-6-2016$ & $20-6-2016$ \\
\hline Dag in het jaar & 320 & 327 & 89 & 96 & 165 & 172 \\
\hline Dag in ronde & 406 & 413 & 540 & 547 & 616 & 623 \\
\hline $\mathrm{CO}_{2}$ stal $[\mathrm{ppm}]$ & 1566 & 2310 & 2175 & 1955 & 1150 & 1083 \\
\hline $\mathrm{CO}_{2}$ buiten $[\mathrm{ppm}]$ & 396 & 396 & 394 & 396 & 392 & 396 \\
\hline Debiet $\left[\mathrm{m}^{3} / \mathrm{uur} / \mathrm{dier}\right]$ & 1,8 & 1,1 & 1,2 & 1,4 & 2,8 & 3,1 \\
\hline $\mathrm{NH}_{3}$ stal $[\mathrm{ppm}]$ & 23,12 & 27,66 & 36,51 & 38,33 & 17,57 & 11,88 \\
\hline $\mathrm{NH}_{3}$ buiten $[\mathrm{ppm}]$ & 0,06 & 0,10 & 0,12 & 0,07 & 0,05 & 0,09 \\
\hline $\mathrm{NH}_{3}$-emissie $[\mathrm{g} / \mathrm{dpl} / \mathrm{jaar}]$ & 233,2 & 181,3 & 252,4 & 303,5 & 275,4 & 202,4 \\
\hline PM10 stal $\left[\mathrm{mg} \mathrm{m}^{-3}\right]$ & 4,65 & 5,15 & 2,45 & 2,19 & 2,34 & 1,28 \\
\hline PM10 buiten $\left[\mathrm{mg} \mathrm{m}^{-3}\right]$ & 0,01 & 0,01 & $<0,01$ & $<0,01$ & $<0,01$ & 0,01 \\
\hline PM10-emissie [g/dpl/jaar] & 66,2 & 47,8 & 24,0 & 24,5 & 51,8 & 30,7 \\
\hline Geur stal $\left[\mathrm{OU}_{\mathrm{E}} \mathrm{m}^{-3}\right]$ & 978 & 1184 & 1493 & 1124 & 697 & 478 \\
\hline Geuremissie $\left[O U_{E} / d p l / s\right]$ & 0,44 & 0,35 & 0,46 & 0,40 & 0,49 & 0,37 \\
\hline $\mathrm{CH}_{4}$ stal $[\mathrm{ppm}]$ & 3,66 & 4,63 & 6,28 & 5,31 & 3,47 & 3,09 \\
\hline $\mathrm{CH}_{4}$ buiten $[\mathrm{ppm}]$ & 1,92 & 2,00 & 2,32 & 2,08 & 1,85 & 1,85 \\
\hline $\mathrm{CH}_{4}$-emissie $[\mathrm{g} / \mathrm{dpl} / \mathrm{jaar}]$ & 16,5 & 16,3 & 25,8 & 24,1 & 24,0 & 19,9 \\
\hline $\mathrm{N}_{2} \mathrm{O}$ stal $[\mathrm{ppm}]$ & 0,36 & 0,34 & 0,33 & 0,37 & 0,42 & 0,45 \\
\hline $\mathrm{N}_{2} \mathrm{O}$ buiten [ppm] & 0,32 & 0,31 & 0,32 & 0,36 & 0,40 & 0,44 \\
\hline $\mathrm{N}_{2} \mathrm{O}$-emissie $[\mathrm{g} / \mathrm{dpl} / \mathrm{jaar}]$ & 1,08 & 0,42 & 0,27 & 0,14 & 0,69 & 0,16 \\
\hline
\end{tabular}




\section{Conclusies}

In dit rapport worden de resultaten gerapporteerd van de metingen die in het kader van de Programmatische Aanpak Stikstof (PAS) zijn uitgevoerd om het effect van het verwijderen van strooisel (om een dunne strooisel-laag in de stal te realiseren) op de emissie van ammoniak, fijnstof, geur en overige broeikasgassen (methaan, lachgas) bij het huisvesten van leghennen te bepalen. De metingen zijn uitgevoerd volgens het zogenaamde 'case-control in de tijd' strategie binnen dezelfde stal. Aan het begin van een meetperiode werd een 24-uursmeting verricht in de stal zoals aangetroffen, d.w.z. met een dikke strooisel-laag (controle-meting). Daarna werd een deel van de strooisel uit de stal verwijderd, en na een periode van 2-3 dagen een tweede 24-uursmeting uitgevoerd in de stal met een dunne strooisel-laag (case-meting).

$\mathrm{NH}_{3}$ - en PM10-emissies na verwijdering van strooisel (case) waren zwak significant $(0,05<\mathrm{P}<0,10)$ verschillend van de emissies vóór verwijdering van strooisel (controle). De gemiddelde $\mathrm{NH}_{3}-$ emissiereductie door het verwijderen van strooisel in de stal over alle metingen was in onderhavige studie $20 \pm 6 \%$. Voor PM10 werd een gemiddelde emissiereductie van $22 \pm 5 \%$ gemeten.

Voor zowel $\mathrm{NH}_{3}$ als PM10 was de dikte van de strooisel-laag na het verwijderen van de strooisel belangrijker dan de hoeveelheid strooisel die verwijderd werd om emissies te kunnen reduceren. De reductie is groter wanneer de dikte van de strooisel-laag na verwijdering kleiner is dan $2-3 \mathrm{~cm}$. In dat geval kan een $\mathrm{NH}_{3}$ - en PM10-emissiereductie van 25-35\% worden bereikt.

Deze studie laat geen significant effect zien door het verwijderen van strooisel in de stal op de geuremissies. Dit komt voornamelijk door de eerste twee meetseries, waar een hogere in plaats van een lagere geuremissies werd gemeten na het verwijderen van het strooisel. De andere zeven meetseries laten zien dat strooiselverwijdering potentie heeft om geuremissies sterk te kunnen reduceren. De gemiddelde emissiereductie van deze zeven metingen was $26 \pm 5 \%$, en het effect was significant $(P<0,05)$. Er is geen direct verband aangetroffen tussen de geuremissie en de dikte van de strooisel-laag na het verwijderen van de strooisel, of tussen de geuremissie en de hoeveelheid strooisel die verwijderd werd.

De data in onderhavige studie laat geen significant effect zien van het verwijderen van strooisel in de stal op de $\mathrm{CH}_{4}$ - en $\mathrm{N}_{2} \mathrm{O}$-emissies. $\mathrm{Er}$ is ook geen directe verband aangetroffen tussen deze emissies en de dikte van de strooisel-laag na het verwijderen van de strooisel, of tussen deze emissies en de hoeveelheid strooisel die werd verwijderd. 


\section{Literatuur}

CEN standard 13725. 2003. Air quality - determination of odour concentration by dynamic olfactometry, European Committee for Standardization, Brussels, Belgium.

CIGR. 2002. 4th Report of Working Group on Climatization of animal houses. Heat and moisture production at animal and house levels (eds. Pedersen, S.; K. Sällvik).

Groenestein, C.M., J. Mosquera en N.W.M. Ogink. 2011. Protocol voor meting van methaanemissie uit huisvestingssystemen in de veehouderij 2010. Rapport 493, Wageningen UR Livestock, Lelystad, The Netherlands.

Groot Koerkamp, P.W.G. and B. Reitsma, 1997. De ammoniakemissie uit een volièrestal voor leghennen met het etagesysteem. Rapport 97-05. DLO-IMAG, Wageningen.

Hofschreuder, P., Y. Zhao, A. J. A. Aarnink, en N. W. M. Ogink. 2008. Measurement protocol for emissions of fine dust from animal housings. Considerations, draft protocol and validation. Report 134, Animal Sciences Group, Lelystad.

Mosquera, J., C.M. Groenestein en N.W.M. Ogink. 2011. Protocol voor meting van lachgasemissie uit huisvestingssystemen in de veehouderij 2010. Rapport 494, Wageningen UR Livestock, Lelystad, The Netherlands.

NEN-EN 12341. 1998. Luchtkwaliteit - bepaling van de pm10 fractie van zwevend stof referentiemethode en veldonderzoek om de referentiegelijkwaardigheid aan te tonen van meetmethoden, Nederlands Normalisatie-instituut, Delft.

NEN-EN 14907. 2005. Ambient air quality - standard gravimetric measurement method for the determination of the pm2,5 mass fraction of suspended particulate matter, Nederlands Normalisatie-instituut, Delft.

Ogink, N.W.M., G. Mol. 2002. Uitwerking van een protocol voor het meten van de geuremissie uit stallocaties en stalsystemen in de veehouderij. IMAG nota P 2002-57, 31 pp.

Ogink, N.W.M.. 2011. Protocol voor meting van geuremissie uit huisvestingssystemen in de veehouderij 2010. Rapport 491, Wageningen UR Livestock, Lelystad, The Netherlands.

Ogink, N.W.M., P. Hofschreuder en A.J.A. Aarnink. 2011. Protocol voor meting van fijnstofemissie uit huisvestingssystemen in de veehouderij 2010. Rapport 492, Wageningen UR Livestock, Lelystad, The Netherlands.

Ogink, N.W.M., J. Mosquera en J.M.G. Hol. 2013. Protocol voor meting van ammoniakemissie uit huisvestingssystemen in de veehouderij 2013. Rapport 726, Wageningen UR Livestock, Lelystad, The Netherlands.

Pedersen, S., V. Blanes-Vidal, M.J.W. Heetkamp, en A.J.A. Aarnink. 2008. Carbon dioxide production in animal houses: A literature review. Agricultural Engineering International: CIGR Ejournal. Manuscript BC 08 008, Vol. X. December, 2008.

Van Emous, R.A., H.H. Ellen, en Th.G.C.M. Fiks-van Niekerk. 2004. Inrichting, verlichting, ammoniak en stof bij volièreonderzoek ( $2^{\mathrm{e}}$ proef). Praktijk Rapport Pluimvee 14.

Van Emous, R.A., J. van Harn, en A.J.A. Aarnink. 2009. Maatregelen ter vermindering van fijnstofemissie uit de pluimveehouderij: effecten van strooisellaagdikte. Rapport 254, Animal Sciences Group, Lelystad, The Netherlands.

Van Harn, J., H.H. Ellen, T. Veldkamp, A.J.A. Aarnink, 2012. Effect van huisvestings- en

managementmaatregelen op de ammoniakemissie bij leghennen, vleeskuikens, kalkoenen en eenden. Wageningen UR Livestock Research 560, Lelystad. Nog niet gepubliceerd.

Winkel, A., J. Mosquera, J.M.G. Hol, G.M. Nijeboer, N.W.M. Ogink, en A.J.A. Aarnink. 2011. Fijnstofemissie uit stallen: leghennen in volièrehuisvesting. Wageningen UR Livestock Research Rapport 278.

Wintjens, Y. 1993. Gaswasfles. In Meetmethoden $\mathrm{NH}_{3}$-emissie uit stallen. Onderzoek inzake de mesten ammoniak- problematiek in de veehouderij 16 (eds E.N.J. van Ouwerkerk), pp. 38-40. DLO, Wageningen.

Zhao, Y., A.J.A. Aarnink, P. Hofschreuder, en P.W.G. Groot Koerkamp. 2009. Validation of cyclone as a pre-separator for airborne dust sampling in animal houses. Aerosol Science 40: 868 - 878. 


\section{Bijlage 1 Foto's van de bedrijfssituatie}

\section{Meetlocatie 1}

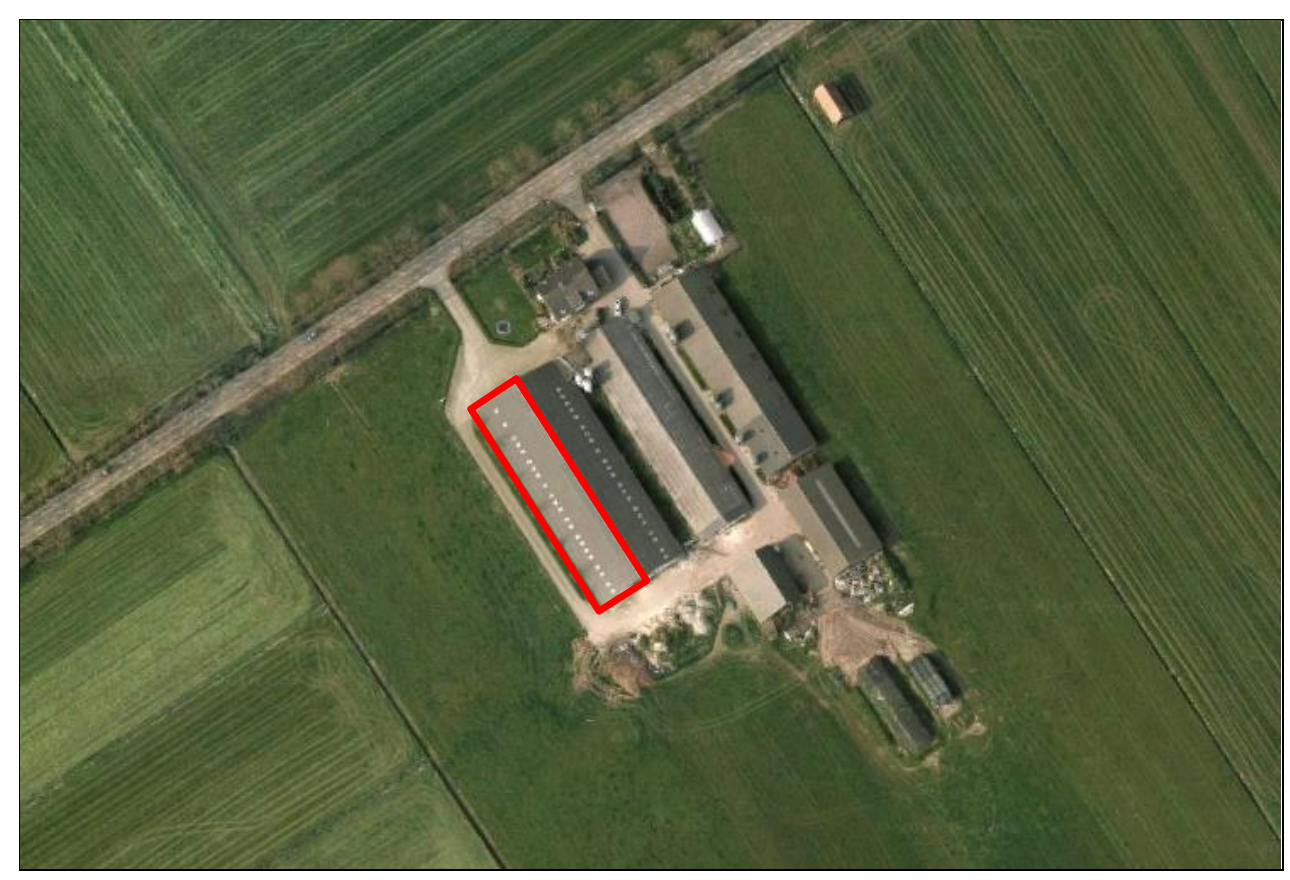

Luchtfoto (Google maps)

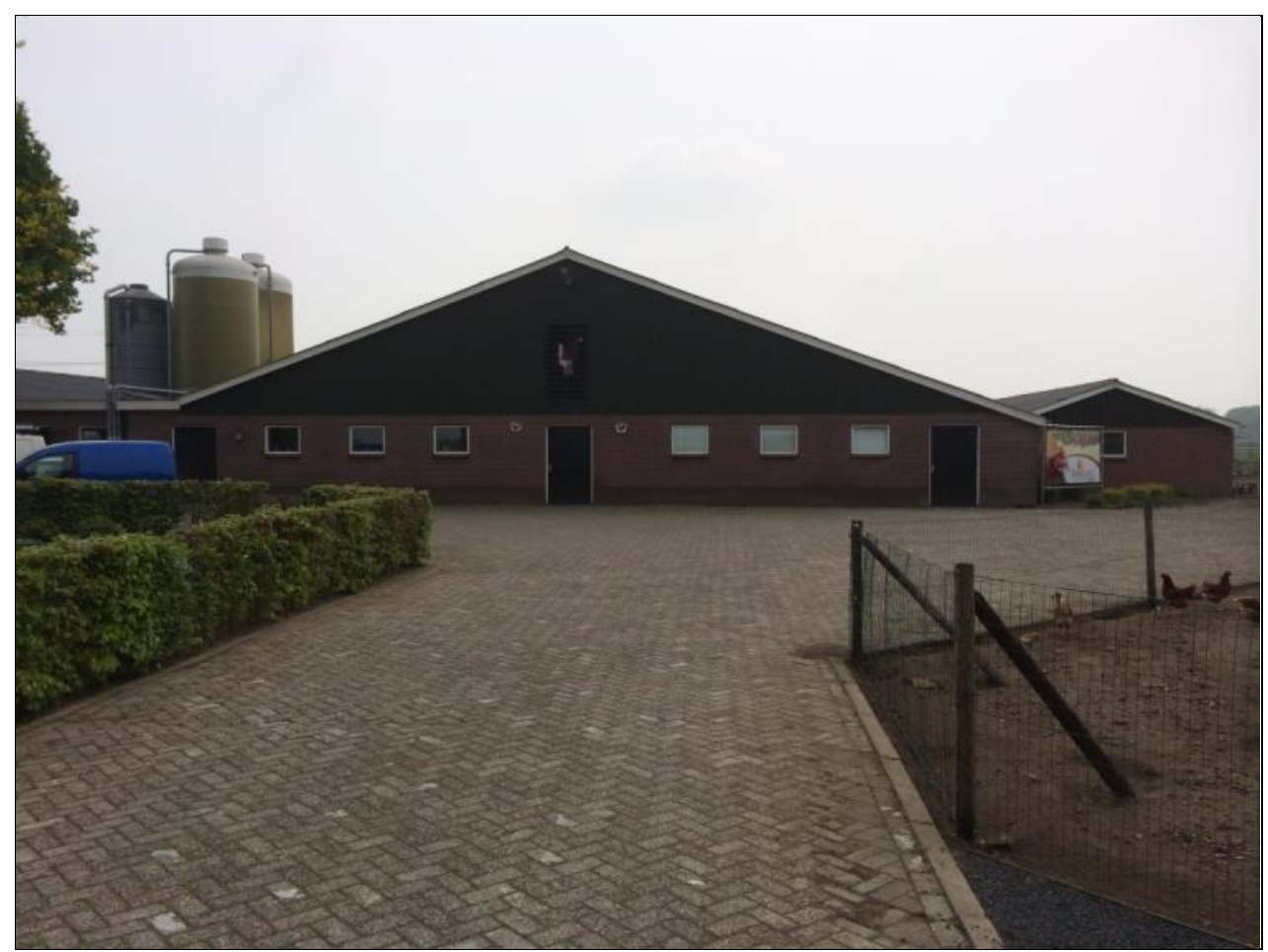

Buitenkant van de stal 


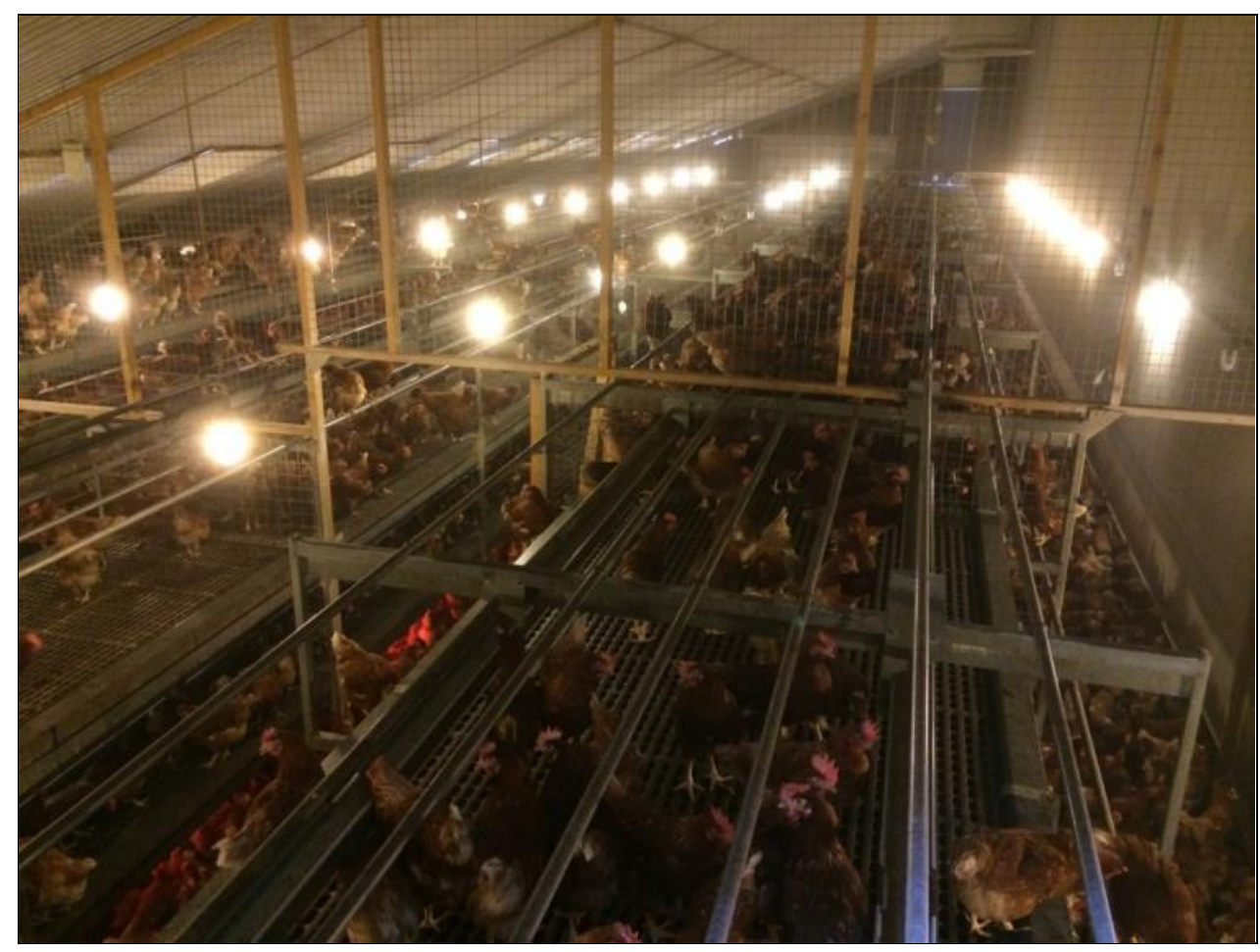

Binnenzijde stal

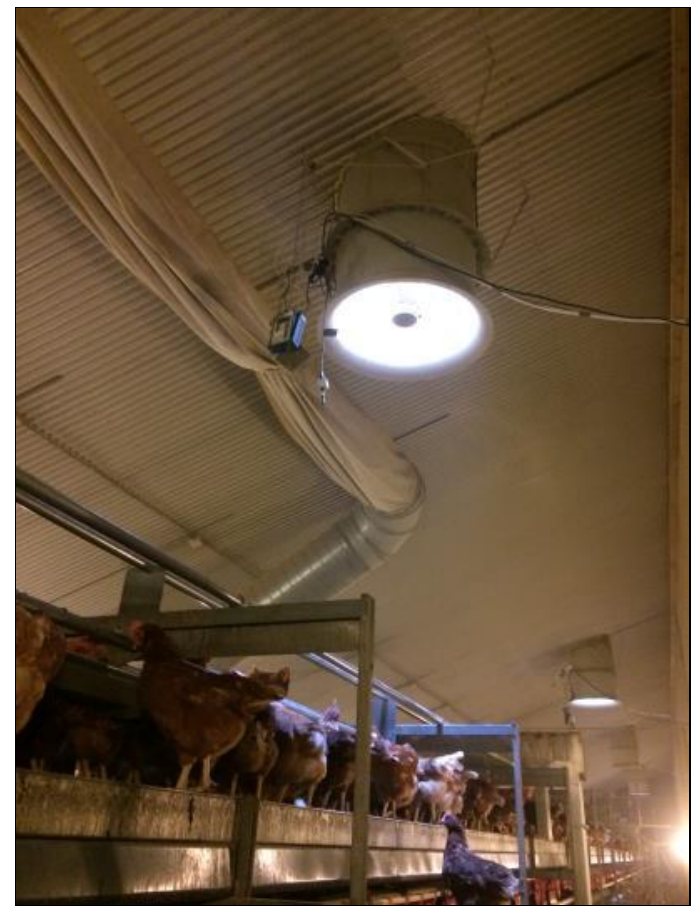

Luchtuitlaat met ventilatoren (binnenzijde)

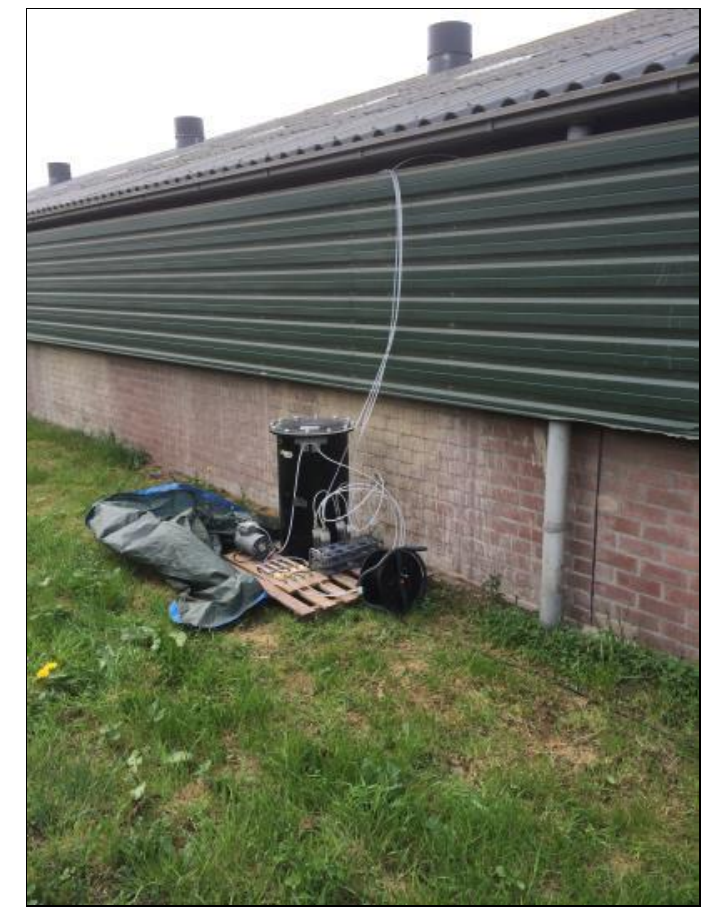

Buitenkant van de stal met meetapparatuur 


\section{Meetlocatie 2}

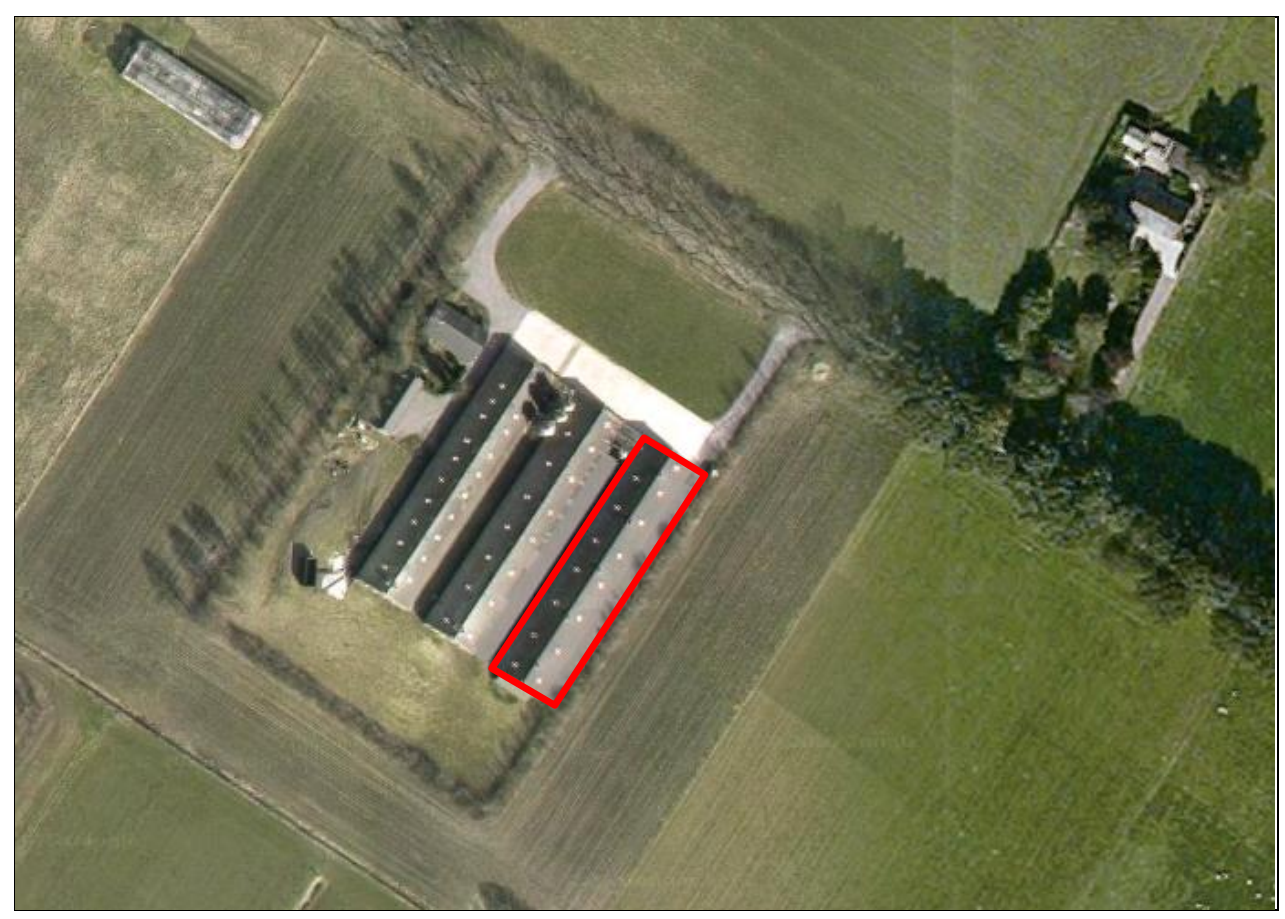

Luchtfoto (Google maps)

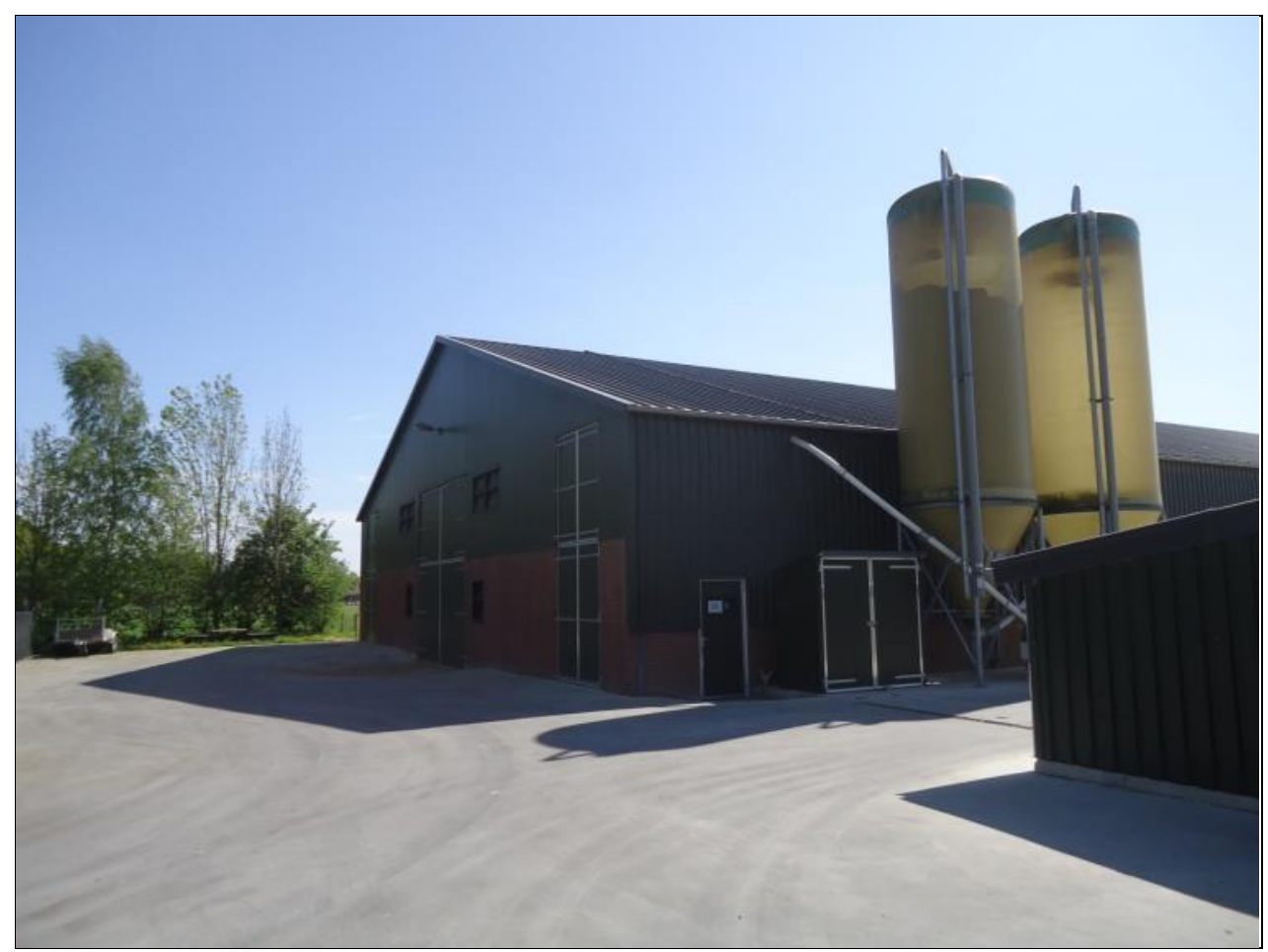

Buitenkant van de stal 


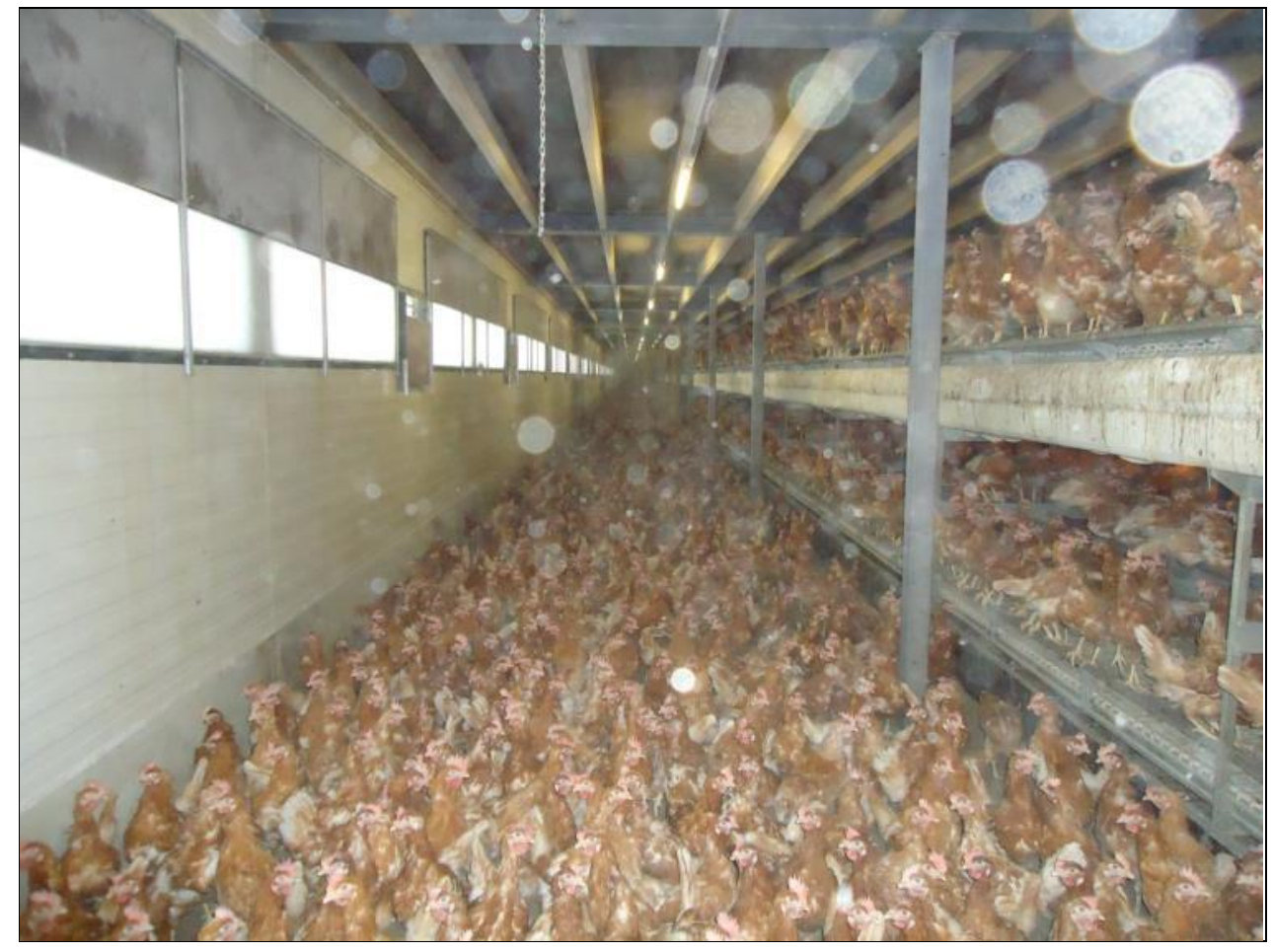

Binnenzijde stal

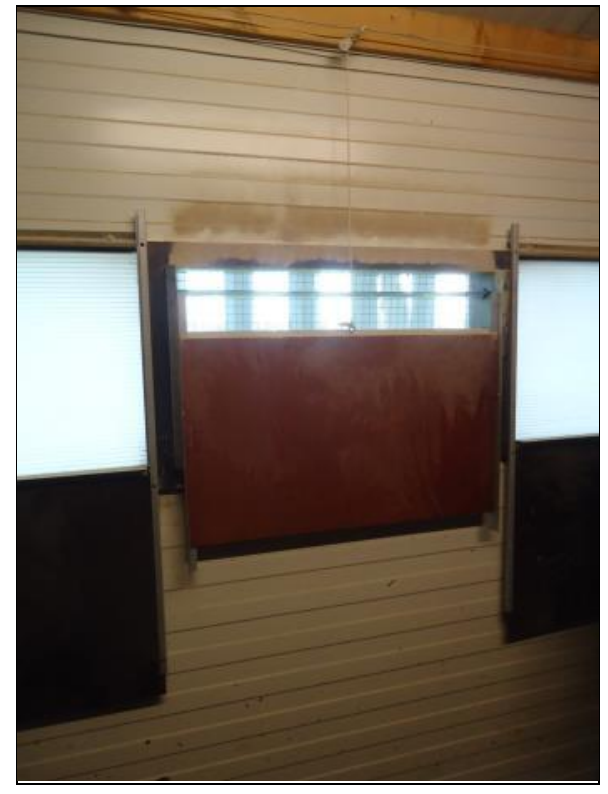

Luchtinlaat (binnenzijde)

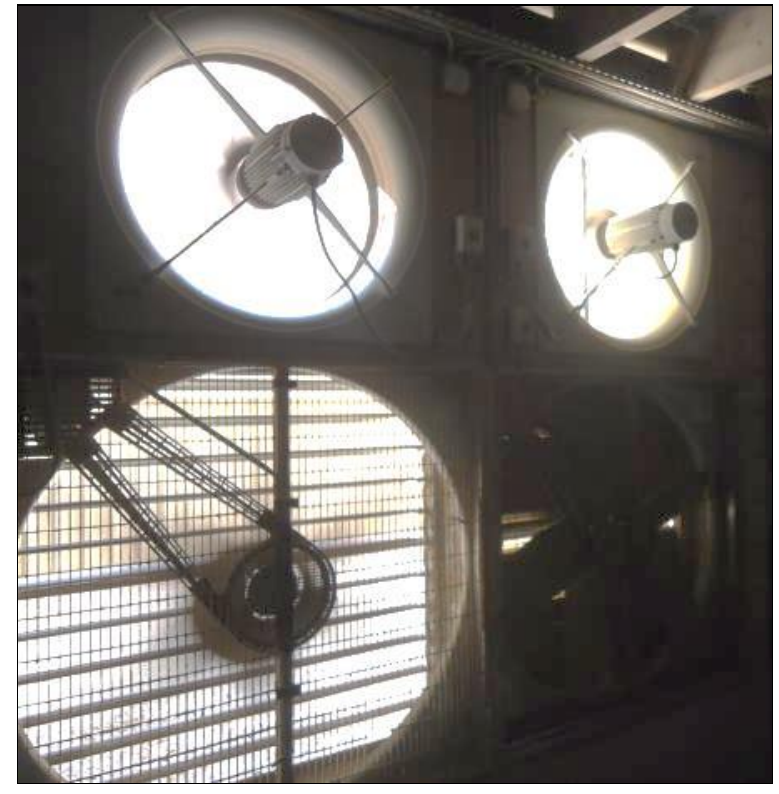

Luchtuitlaat met ventilatoren (binnenzijde) 


\section{Meetlocatie 3}

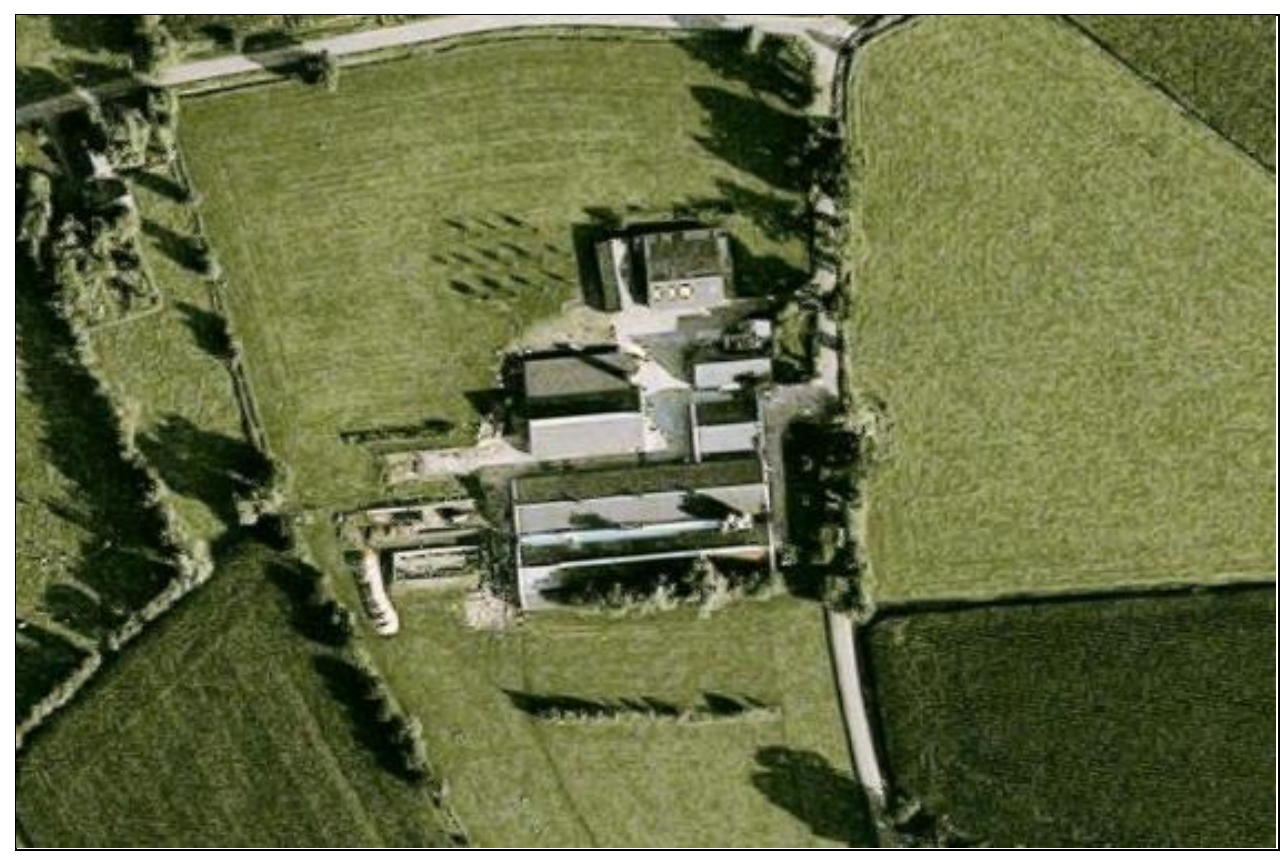

Luchtfoto (Google maps)

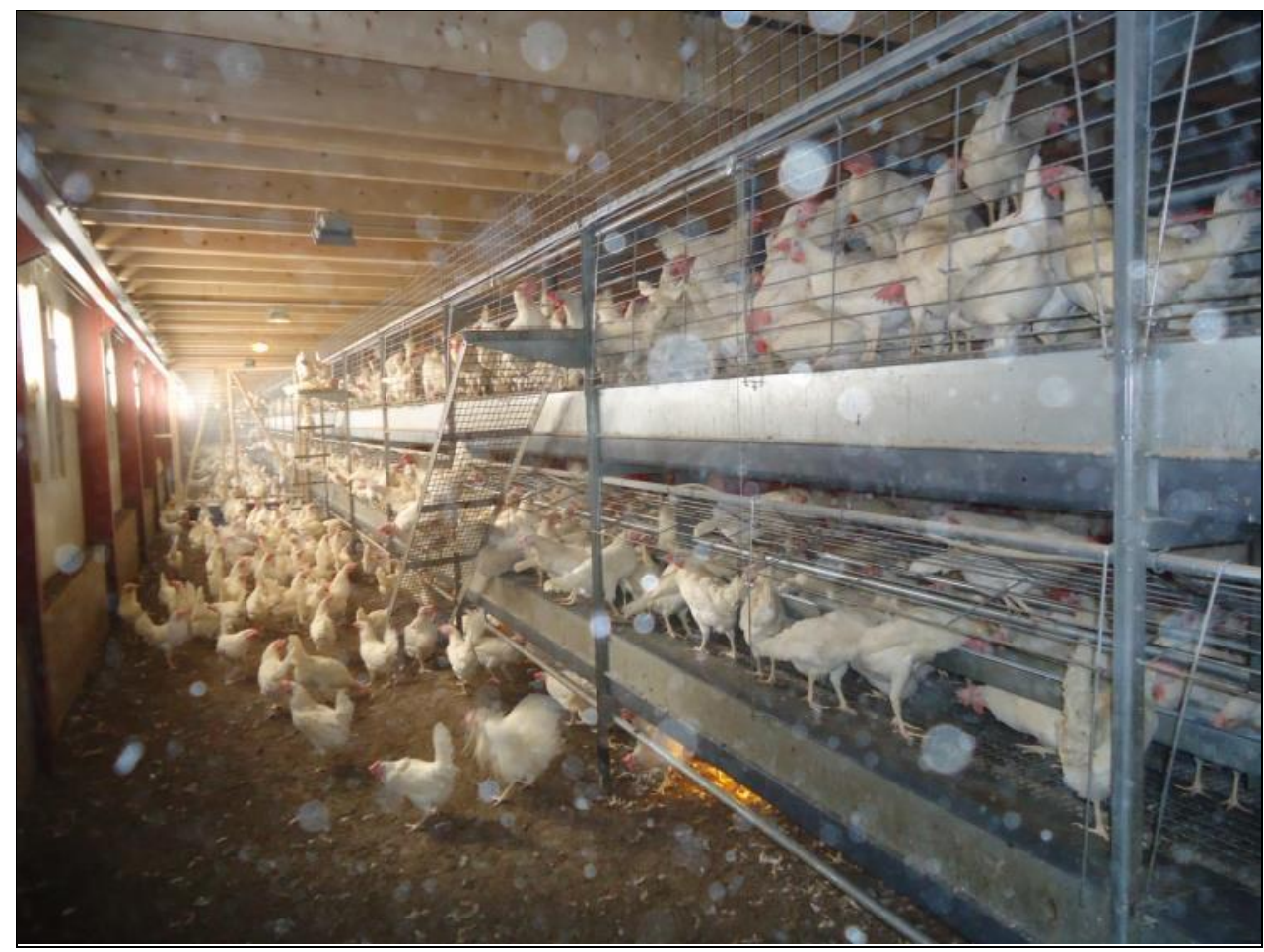

Binnenzijde stal 


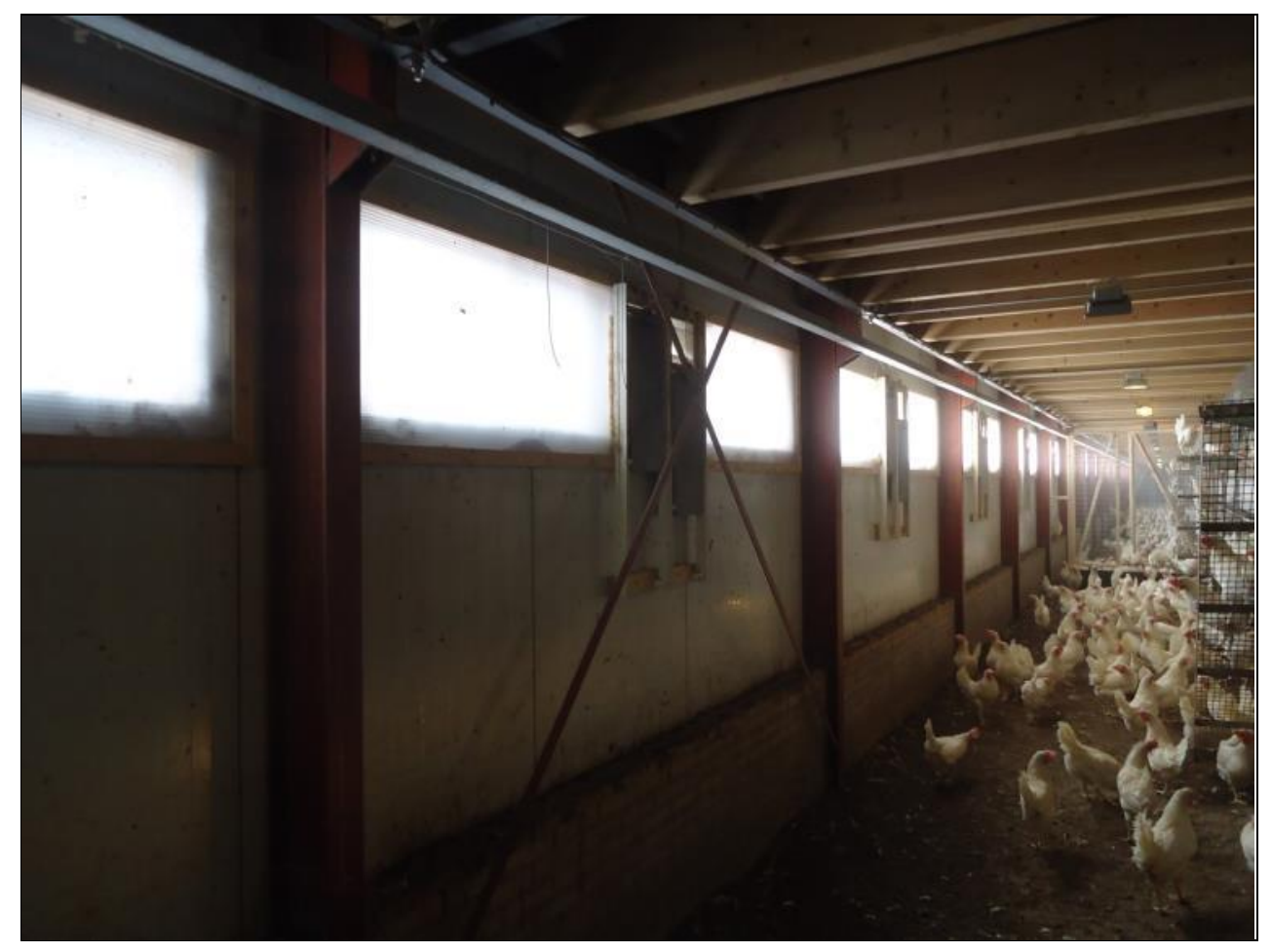

Luchtinlaat (binnenzijde)

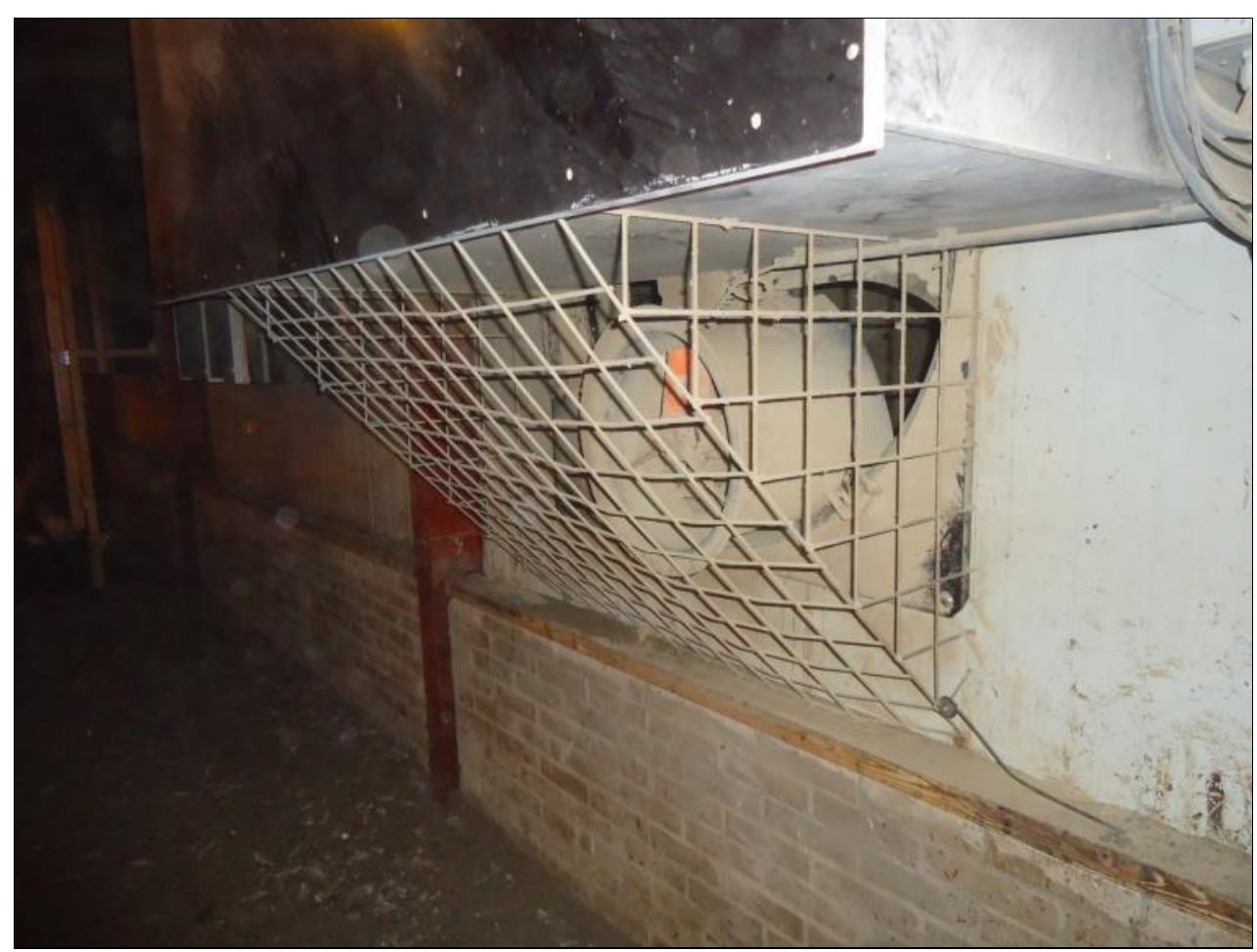

Luchtuitlaat met ventilatoren (binnenzijde) 
Meetlocatie 4

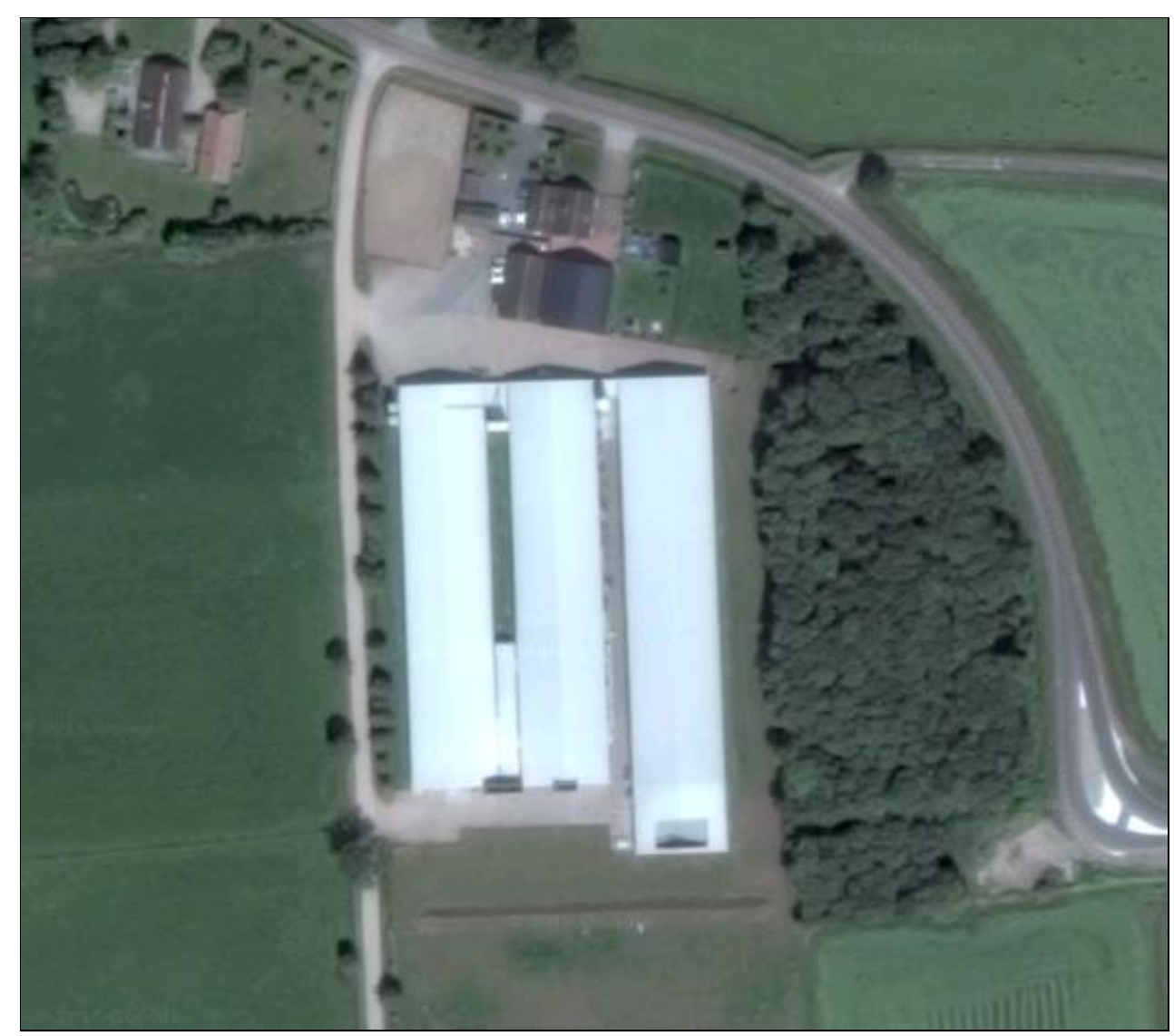

Luchtfoto (Google maps)

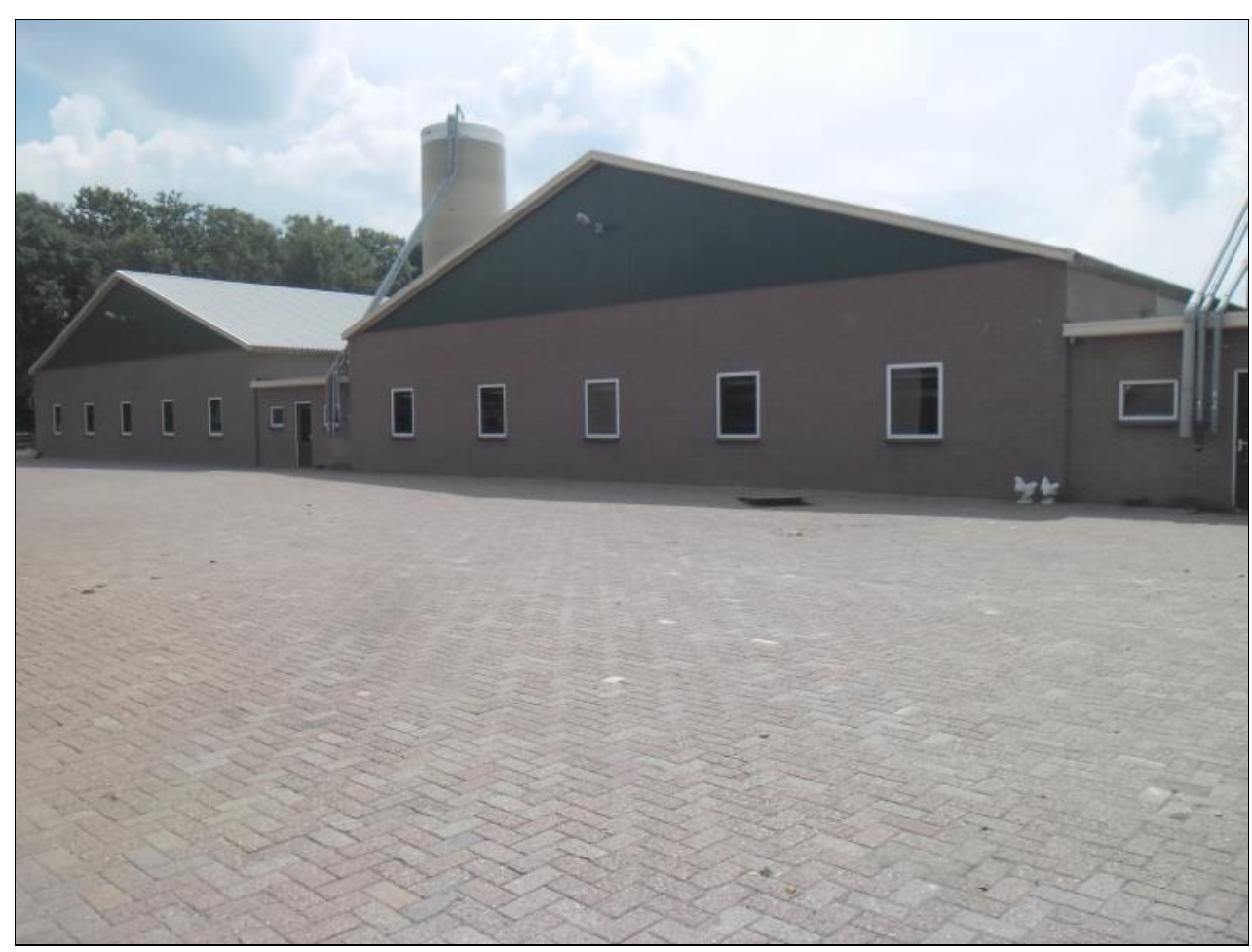

Buitenkant van de stal 


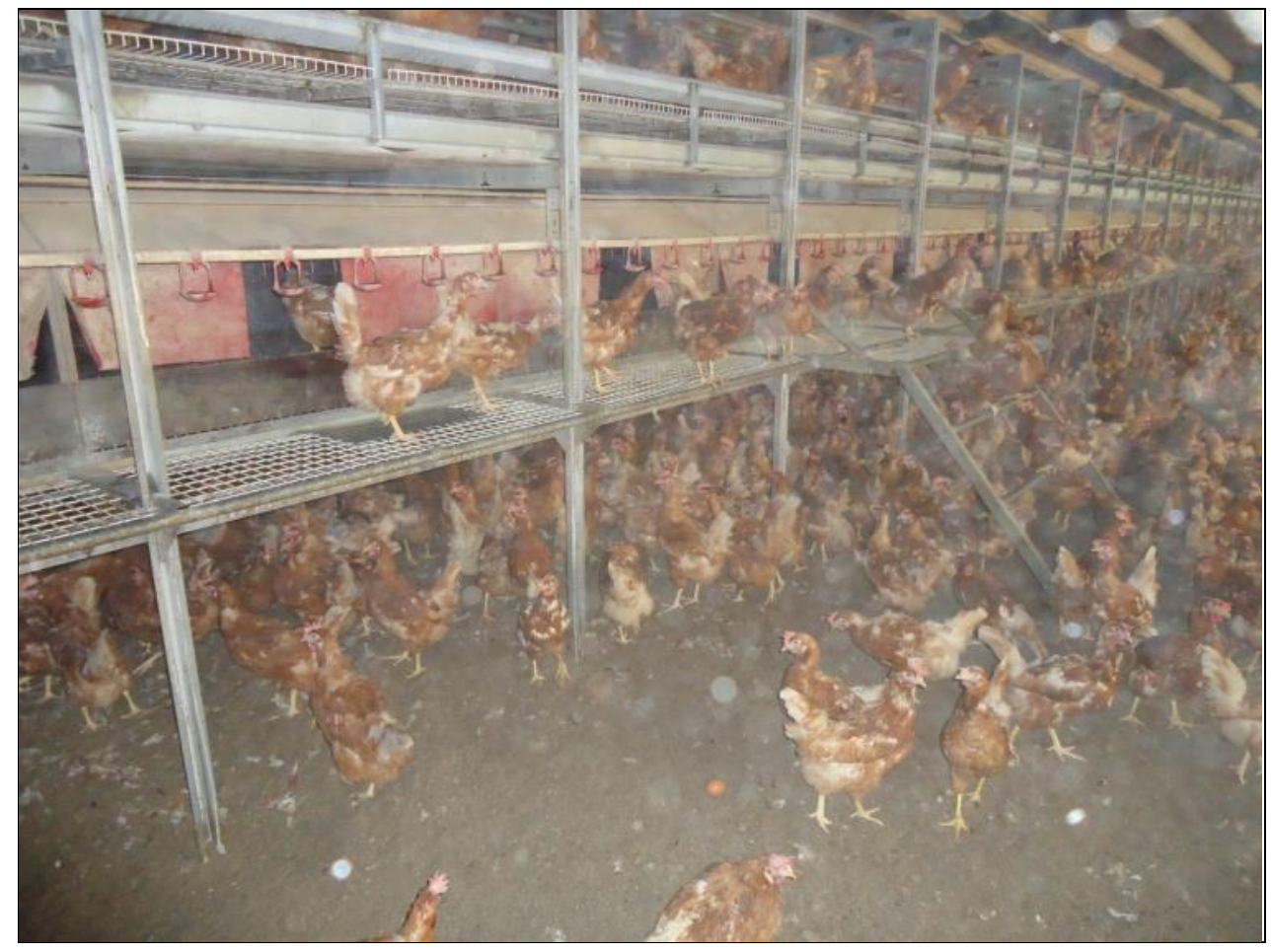

Binnenzijde stal

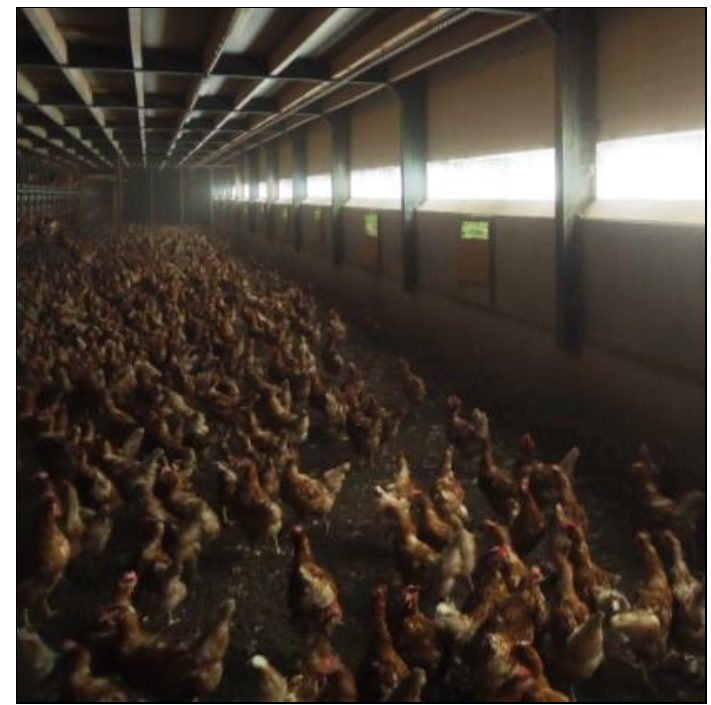

Luchtinlaat (binnenzijde)

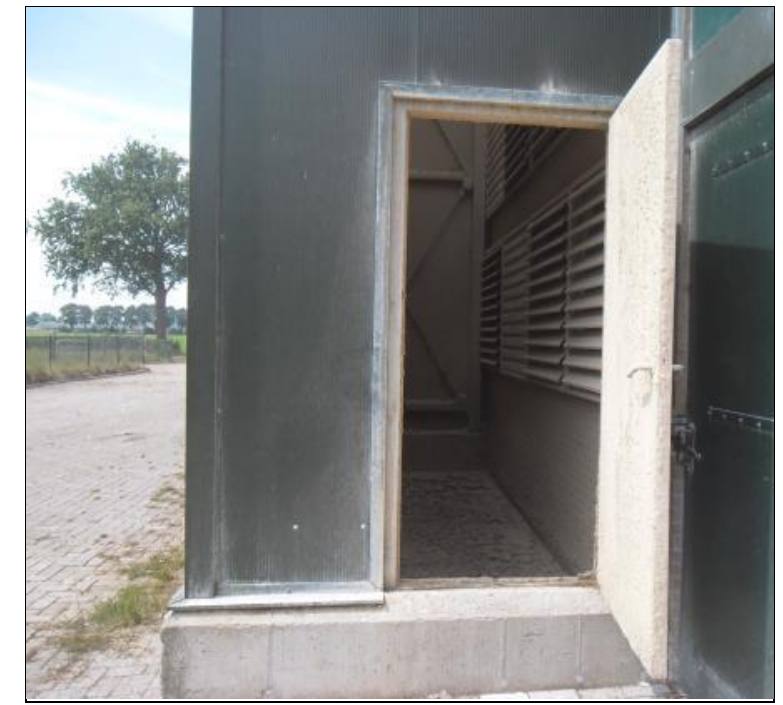

Luchtuitlaat met ventilatoren 


\section{Meetlocatie 5}

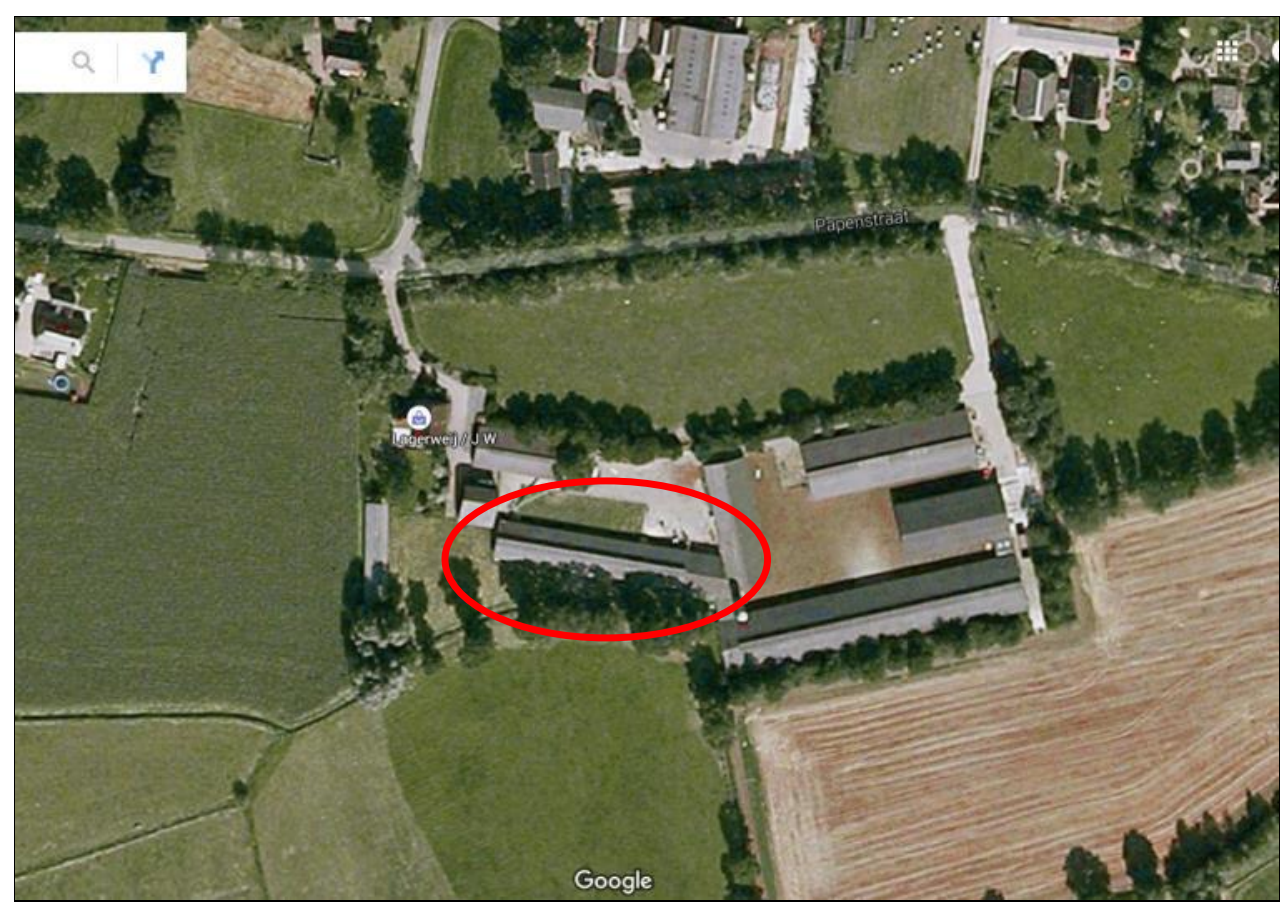

Luchtfoto (Google maps)

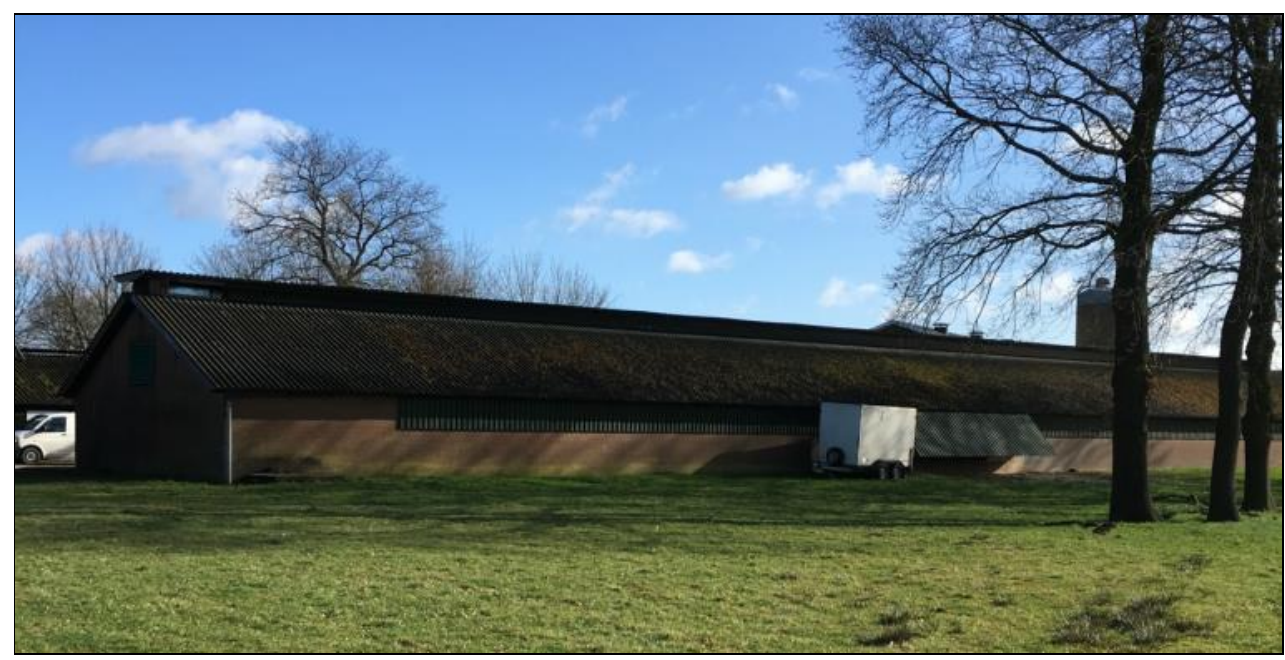

Buitenkant van de stal 


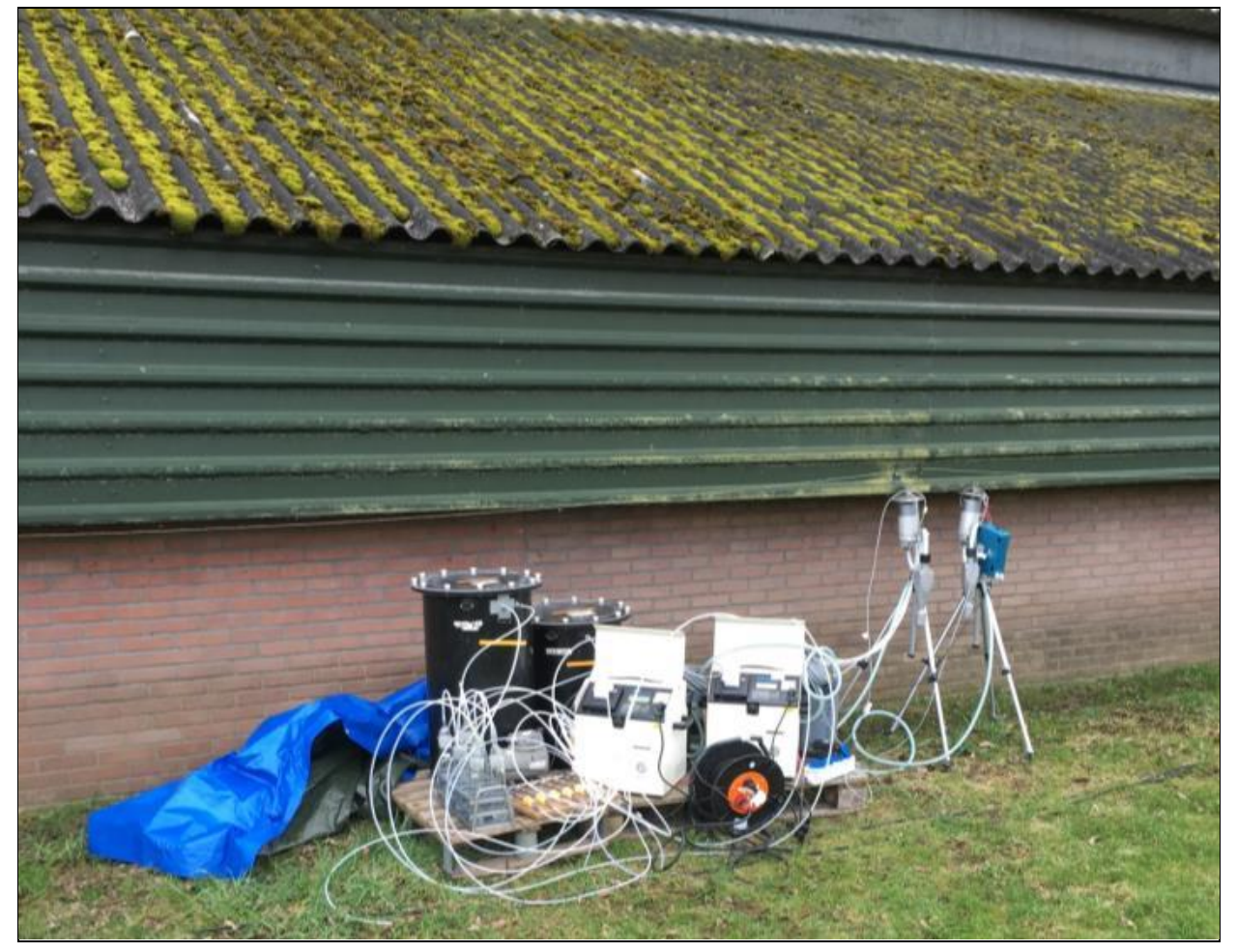

Luchtinlaat (buitenzijde)

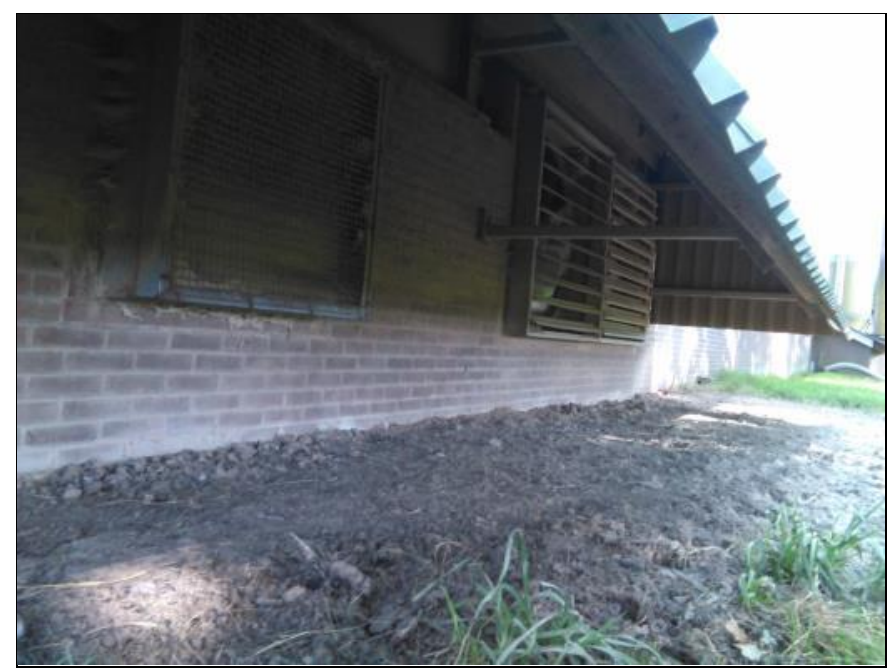

Luchtuitlaat met ventilatoren (buitenzijde)

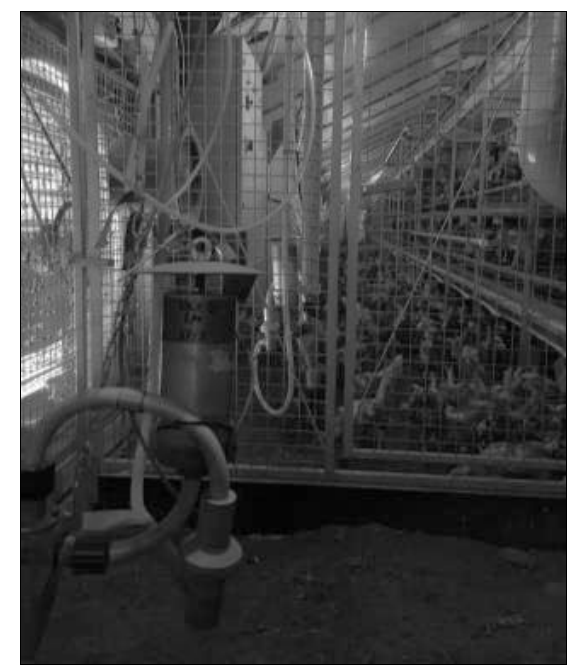

Luchtuitlaat (binnenzijde) 


\section{Bijlage 2 Voersamenstelling}

\section{Meetlocatie 1}

Volledig diervoeder voor legkippen. Uitsluitend te gebruiken voor doeldieren.

Dit voer is geschikt voor kat-productie en voldoet aan de voorwaarden van Voederwaarde.nl.

Analytische bestanddelen (per $\mathrm{kg})$ :

$\begin{array}{lcc}\text { Ruw as } & 127 & \mathrm{~g} \\ \text { Ruw eiwit } & 160 & \mathrm{~g} \\ \text { Ruw vet } & 51 & \mathrm{~g} \\ \text { Ruw celstof } & 44 & \mathrm{~g} \\ \text { Lysyne } & 7,6 & \mathrm{~g} \\ \text { Methionine } & 3,8 \mathrm{~g} \\ \text { Calcium } & 40 & \mathrm{~g} \\ \text { Fosfor } & 4,7 \mathrm{~g} \\ \text { Natrium } & 1,8 \mathrm{~g}\end{array}$

Samenstelling:

Maïs (uit gg maïs), Tarwe, Zonnebloemzaadschroot, Koolzure voederkalk, Sojaproducten (uit gg soja), Kool- en raapzaadschroot, Dierlijk vet, Premix, Maïsglutenmeel, Natriumchlroide, Monocalciumfosfaat, Natriumbicarbonaat.

Vitaminen (per kg):

E672 Vitamine A 10000 IE

E671 Vitamine D3 2250 IE

Vitamine E (Eq.) 25 IE

Spoorelementen (per kg):

E4 Cu (Cu-sulfaat) $10 \mathrm{mg}$

E6 Zn (Zn-sulfaat) 100 mg

Verteringsbevorderaars (per $\mathrm{kg}$ ):

$4 a 1600$ 3-fytase

E1604 endo-1, 4-beta-xylanase

E1604 endo-1, 3(4)-beta-glucanase

Kleurstoffen (per kg):

E16 1i citranaxanthine $3,5 \mathrm{mg}$ 


\section{Meetlocatie 2}

Volledig diervoeder voor leghennen.

Analytische bestanddelen (per $\mathrm{kg})$ :

\begin{tabular}{|c|c|c|}
\hline Ruw as & 116 & $\mathrm{~g}$ \\
\hline Ruw eiwit & & 159 \\
\hline Ruw vet & & 55 \\
\hline Ruw celstof & & 52 \\
\hline Lysine & & 7,8 \\
\hline Methionine & & 3,9 \\
\hline Calcium & 34 & $g$ \\
\hline Fosfor & & 5,0 \\
\hline Natrium & 1,6 & $\mathrm{~g}$ \\
\hline
\end{tabular}

Sensoriële toevoegmiddelen (per $\mathrm{kg}$ ):

E161g Canthaxanthine $3,0 \mathrm{mg}$

Nutritionele toevoegmiddelen (per $\mathrm{kg}$ ):

$\begin{array}{lcc}\text { E672 Vitamine A } & 7508 & \mathrm{IE} \\ \text { E671 Vitamine D3 } & 2252 & \mathrm{IE} \\ \text { E3a700 Vitamine E (all-rac-alfatocoferocetaat) } & 10 & \mathrm{mg} \\ \text { E4 Kopersulfaat, pentahydraat } & 15 & \mathrm{mg} \\ \text { E6 Zinksulfaat, monohydraat } & 55 & \mathrm{mg} \\ \text { E5 Mangaan oxide } & 70 & \mathrm{mg} \\ \text { E8 Natrium seleniet } & 0,2 & \mathrm{mg} \\ \text { E2 Kaliumiodide } & 1 & \mathrm{mg} \\ \text { E1 IJzersulfaat, monohydraat } & 40 & \mathrm{mg} \\ & & \\ \text { Zoötechnische toevoegmiddelen (per kg): } & 352 & \mathrm{FTU} \\ \text { E4a1640 6-fytase EC 3.1.3.26 } & 1055 & \text { EPU } \\ \text { E1606 Endo 1, 4-beta Xylanase } & & \end{array}$

Samenstelling:

Maïs $^{(1)}$, Tarwe, Zonnebloemzaadschroot, Calciumcarbonaat, Kool- en raapzaadschroot, Sojaschroot, Getoast $^{(2)}$ plantaardige olie (palm), Gefermenteerde maïs, Plantaardige olie (soja), Premix, Vetzuren, Maïskiemen, Voederfosfaat, Dierlijk vet, Natriumchloride, Natrium-bicarbonaat.

Bevat dicalciumfosfaat uit ontvette beenderen: niet geschikt voor het vervoederen aan herkauwers.

(1) Geproduceerd met genetisch gemodificeerde maïs

(2) Geproduceerd uit genetisch gemodificeerde sojabonen 
Meetlocatie 3

Volledig diervoeder voor leghennen.

\begin{tabular}{lcrcr}
\hline Rantsoensamenstelling & DS & Rantsoen & $\begin{array}{c}\text { Rantsoen } \\
(88,96 \text { DS })\end{array}$ & $\begin{array}{c}\text { Droog } \\
(100 \mathrm{DS})\end{array}$ \\
\hline Ingrediënt & \multicolumn{1}{c}{$\%$} & $\mathrm{Kg}$ & \multicolumn{1}{c}{$\%$} & \multicolumn{1}{c}{$\%$} \\
\hline 1062.00 TARWE (2013) & 86,00 & 11,00 & 11,00 & 10,63 \\
1091.01 MAIS (AO-EU) & 86,50 & 44,21 & 44,21 & 42,99 \\
1364.00 BRAZ SOYASCHROOT HIPRO & 87,90 & 7,95 & 7,95 & 7,86 \\
2131.00 SOJAOLIE & 99,50 & 0,60 & 0,60 & 0,67 \\
8520.00 CACO3/EISCHALEN & 99,00 & 6,00 & 6,00 & 6,68 \\
14771.00 Legmeel 1 dd aanvullend verbeek & 91,70 & 30,24 & 30,24 & 31,17 \\
\cline { 3 - 5 } & & 100,00 & 100,00 & 100,00
\end{tabular}

\section{Analyse rantsoen}

\begin{tabular}{|c|c|c|c|c|c|c|c|c|c|}
\hline Code & Omschrijving & $\begin{array}{c}\text { Rantsoen } \\
\text { (88,96 DS ) }\end{array}$ & Compl & & Code & Omschrijving & $\begin{array}{c}\text { Rantsoen } \\
(88,96 \text { DS ) }\end{array}$ & Compl & \\
\hline 001 & $\operatorname{Re}$ & 160,00 & 239,32 & $\mathrm{~g}$ & 028 & bCap & 36,00 & 53,52 & $\mathrm{~g}$ \\
\hline 002 & Rvet & 48,40 & 77,54 & $\mathrm{~g}$ & 030 & $\mathrm{BPp}$ & 1,37 & 2,01 & $\mathrm{~g}$ \\
\hline 003 & $\mathrm{RC}$ & 47,43 & 105,54 & $g$ & 032 & oP mild & 3,10 & 7,78 & $\mathrm{~g}$ \\
\hline 004 & As & 123,44 & 183,38 & $\mathrm{~g}$ & 033 & oPintens & 3,04 & 7,69 & $g$ \\
\hline 007 & Zetmeel & 372,23 & 64,77 & $g$ & 050 & V.LYSp & 6,50 & 10,54 & $\mathrm{~g}$ \\
\hline 026 & $\mathrm{Ca}$ & 34,66 & 49,07 & $\mathrm{~g}$ & 051 & V.METp & 3,54 & 7,15 & $\mathrm{~g}$ \\
\hline 031 & $P$ & 4,98 & 10,29 & g & 052 & V.M+Cp & 5,95 & 10,65 & $\mathrm{~g}$ \\
\hline 036 & $\mathrm{Na}$ & 1,40 & 4,39 & $\mathrm{~g}$ & 222 & Opl. NSPp & 26,61 & 48,29 & $\mathrm{~g}$ \\
\hline 037 & $\mathrm{~K}$ & 6,92 & 10,53 & $g$ & $181 / 0$ & v NEAZ p/v Lys $p$ & p 11,06 & 9,84 & \\
\hline 086 & C18:2 & 21,73 & 32,54 & $\mathrm{~g}$ & & & & & \\
\hline 300 & Vit.A & $10.050,25$ & $33.233,43$ & ie & 351 & Citranax & 4,23 & 14,00 & $\mathrm{mg}$ \\
\hline 301 & Vit.D3 & $2.512,56$ & $8.308,36$ & ie & & & & & \\
\hline 302 & Vit.E & 25,13 & 83,08 & ie & & & & & \\
\hline 006 & Ds & 889,58 & 917,03 & $\mathrm{~g}$ & & & & & \\
\hline 013 & E_Leg & $2.850,00$ & $2.215,84$ & kcal & & & & & \\
\hline
\end{tabular}

\begin{tabular}{llr}
\hline \multicolumn{3}{l}{ Complementsamenstelling } \\
\hline 1049.00 & GERST (GEWALST) & $3,307 \%$ \\
1125.00 & MAISGL.VOERM. 20-23\% RE & $18,201 \%$ \\
1164.00 & TARWEGRIES kwaliteit & $6,613 \%$ \\
1352.00 & RAAPZAADSCHROOT & $16,024 \%$ \\
1395.00 & ZONNEBL.Z.SCHR. 38RE & $34,486 \%$ \\
2185.00 & LECITHINE & $6,010 \%$ \\
2436.00 & SALCURB RM EXTRA LIQUID & $0,050 \%$ \\
2510.00 & KALKSTEENTJES (grof) & $10,800 \%$ \\
2521.00 & MONO-CAL-FOSFAAT & $0,486 \%$ \\
2526.00 & NATRIUMBICARBONAAT & $0,554 \%$ \\
2531.00 & ZOUT & $0,554 \%$ \\
2808.00 & METHIONINE (DL,99\%) & $0,301 \%$ \\
2813.00 & L-LYSINE HCL & $0,397 \%$ \\
3083.00 & m2863 LEG & $1,323 \%$ \\
3124.00 & m2374 ROOD-HC(Citran & $0,893 \%$ \\
\hline & $\quad$ Totaal & $100,000 \%$
\end{tabular}


Meetlocatie 4

Volledig diervoeder voor legkippen, Kat-waardig.

Analytische bestanddelen (per $\mathrm{kg}$ ):

$\begin{array}{lcc}\text { Ruw as } & 117 & \mathrm{~g} \\ \text { Ruw eiwit } & 162 & \mathrm{~g} \\ \text { Ruw vet } & 50 & \mathrm{~g} \\ \text { Ruw celstof } & 49 & \mathrm{~g} \\ \text { Lysine } & 7,7 & \mathrm{~g} \\ \text { Methionine } & 3,6 \mathrm{~g} \\ \text { Calcium } & 35 & \mathrm{~g} \\ \text { Fosfor } & 4,1 \mathrm{~g} \\ \text { Natrium } & 1,6 \mathrm{~g} \\ \text { Kalium } & 7,2 \mathrm{~g}\end{array}$

Nutritionele toevoegmiddelen (per $\mathrm{kg}$ ):

$\begin{array}{lrc}\text { E672 Vitamine A } & 10000 & \text { IE } \\ \text { E671 Vitamine D3 } & 2500 & \text { IE } \\ \text { E1 IJzersulfaat, monohydraat } & 70 & \mathrm{mg} \\ \text { E6 Zinksulfaat } & 80 & \mathrm{mg} \\ \text { E5 Mangaan oxide } & 80 & \mathrm{mg} \\ \text { E4 Kopersulfaat, pentahydraat } & 15 & \mathrm{mg} \\ \text { E8 Natrium seleniet } & 0,2 \mathrm{mg} \\ \text { E2 Kaliumiodide } & 1 & \mathrm{mg}\end{array}$

Zoötechnische toevoegmiddelen (per $\mathrm{kg}$ ):

E4a1640 6-fytase EC 3.1.3.26

$500 \quad$ FTU

E1606 Endo 1, 4-beta Xylanase EC 3.2.1.8 $\quad 8 \quad$ IU

E16 1i Citranaxanthine $\quad 4,8 \mathrm{mg}$

Samenstelling:

Maïs, Tarwe, Sojaschroot Hipro ${ }^{(1)}$, Zonnebloemzaadschroot, Koolzure voederkalk, Graan bijproduct, Raapschilfers, Plantaardige olie ${ }^{(2)}$, Vetten, Mineralen en vitaminen, Enzymen, Kleurpremix, Zout, Aminozuren, Monodicalciumfosfaat.

(1) Dit product bevat ggo soja

(2) Deze plantaardige olie is afkomstig van ggo soja 


\section{Meetlocatie 5}

Volledig diervoeder voor legkippen.

Het geleverde diervoeder voldoet aan de voorwaarden van GMP+ BCN-NL1 Antibioticavrij diervoeder, KAT (NL-3861-01), en GGE. Voldoet aan de voorwaarden van Voederwaarde.nl

\begin{tabular}{lrr}
\multicolumn{3}{l}{ Analytische bestanddelen } \\
Ruw as & 134 & $\mathrm{~g}$ \\
Ruw eiwit & 162 & $\mathrm{~g}$ \\
Ruw vet & 50 & $\mathrm{~g}$ \\
Ruw celstof & 50 & $\mathrm{~g}$ \\
Lysine & 7,5 & $\mathrm{~g}$ \\
Methionine & 3,7 & $\mathrm{~g}$ \\
Calcium & 41,5 & $\mathrm{~g}$ \\
Fosfor & 4,9 & $\mathrm{~g}$ \\
Natrium & 1,5 & $\mathrm{~g}$
\end{tabular}

Nutritionele toevoegmiddelen (per $\mathrm{kg})$ :

\begin{tabular}{lrc}
\hline E672 Vitamine A & 10000 & IE \\
E671 Vitamine D3 & 2510 & IE \\
Vitamine E & 25 & IE \\
E4 Kopersulfaat, pentahydraat & 15 & $\mathrm{mg}$ \\
E1 IJzersulfaat & 80 & $\mathrm{mg}$ \\
E5 Mangaan oxide & 101 & $\mathrm{mg}$ \\
E6 Zinksulfaat , monohydraat & 101 & $\mathrm{mg}$ \\
E2 Kaliumiodide & 2 & $\mathrm{mg}$ \\
E8 Natrium seleniet & $0,3 \mathrm{mg}$ \\
& & \\
Zoötechnische toevoegmiddelen (per kg): & & \\
E4a1640 6-fytase EC 3.1.3.26 & 600 & FTU \\
E1606 Endo 1, 4-beta Xylanase EC 3.2.1.8 & 10 & FTU
\end{tabular}

Technologische toevoegmiddelen (per $\mathrm{kg}$ ):

$\begin{array}{ll}\text { E324 Ethoxyquine } & 0,2 \mathrm{mg} \\ \text { E310 Propylgalaat } & 1 \mathrm{mg} \\ \text { E321 BHT } & 2 \mathrm{mg}\end{array}$

Samenstelling:

Maïs $^{(2)}$, Zonnebloemzaadschroot, Tarwe, Koolzure voederkalk, Sojaschroot ${ }^{(1)}$, Raapzaadschroot, Raapschilfers, Tarweglutenvoermeel, Soja olie lecithine ${ }^{(1)}$, Soja olie vetzuren ${ }^{(1)}$, Natriumbicarbonaat, Soja olie ${ }^{(1)}$, Pluimvee vet, Palmolie, Natriumchloride, Monocalciumfosfaat.

(1) Dit product is geproduceerd uit genetisch gemodificeerde soyabonen

(2) Dit product is geproduceerd uit genetisch gemodificeerde maïs 


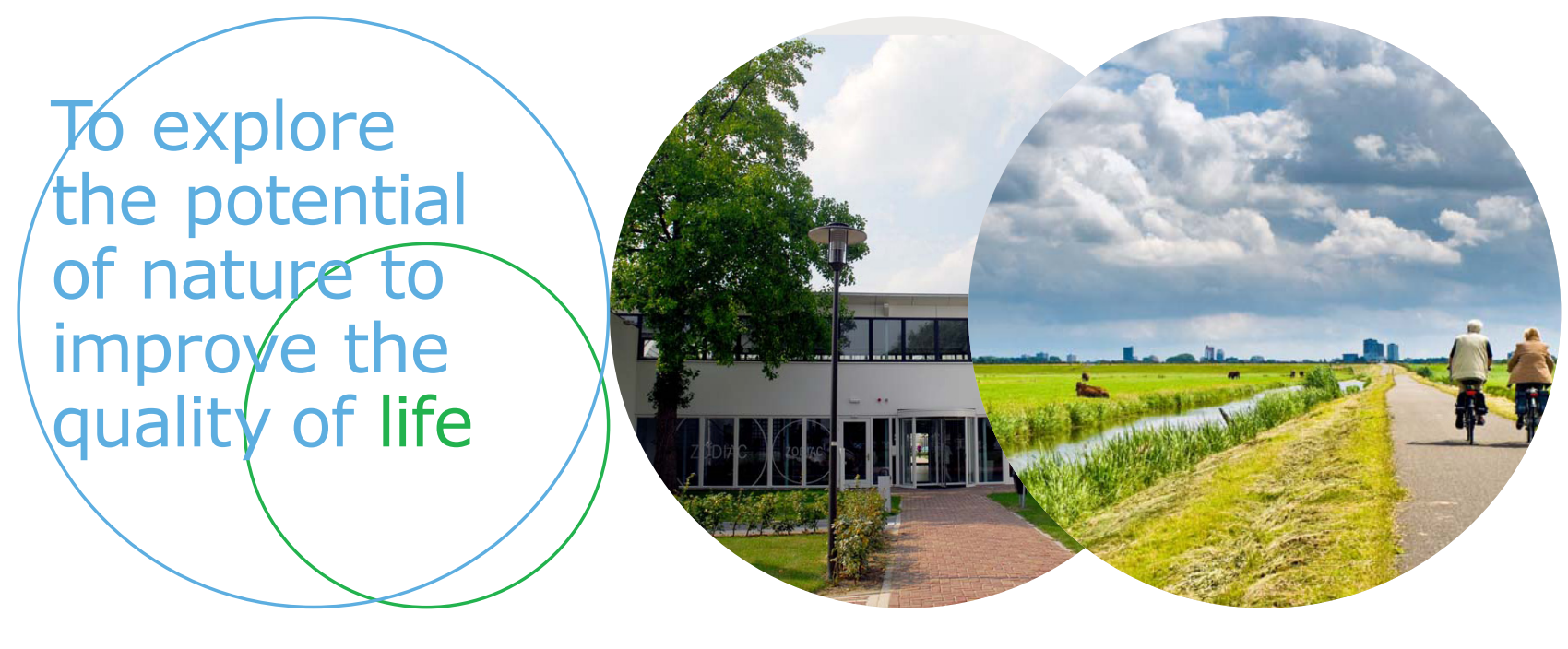

Wageningen Livestock Research Postbus 338

$6700 \mathrm{AH}$ Wageningen

T 0317483953

E info.livestockresearch@wur.nl www.wur.nl/livestock-research
Wageningen Livestock Research ontwikkelt kennis voor een zorgvuldige en renderende veehouderij, vertaalt deze naar praktijkgerichte oplossingen en innovaties, en zorgt voor doorstroming van deze kennis. Onze wetenschappelijke kennis op het gebied van veehouderijsystemen en van voeding, genetica, welzijn en milieu-impact van landbouwhuisdieren integreren we, samen met onze klanten, tot veehouderijconcepten voor de $21 \mathrm{e}$ eeuw.

De missie van Wageningen University \& Research is 'To explore the potential of nature to improve the quality of life'. Binnen Wageningen UR bundelen 9 gespecialiseerde onderzoeksinstituten van stichting DLO en Wageningen University hun krachten om bij te dragen aan de oplossing van belangrijke vragen in het domein van gezonde voeding en leefomgeving. Met ongeveer 30 vestigingen, 6.000 medewerkers en 10.000 studenten behoort Wageningen UR wereldwijd tot de aansprekende kennisinstellingen binnen haar domein. De integrale benadering van de vraagstukken en de samenwerking tussen verschillende disciplines vormen het hart van de unieke Wageningen aanpak. 